\title{
GEOLOGY OF THE NORTHERN CHUGACH MOUNTAINS, SOUTHCENTRAL ALASKA
}

By

L.E.Burns, G.H. Pessel, T.A. Liılle, T.L. Pavlis, R.J. Newberry, G.R. Winkler, and John Decker

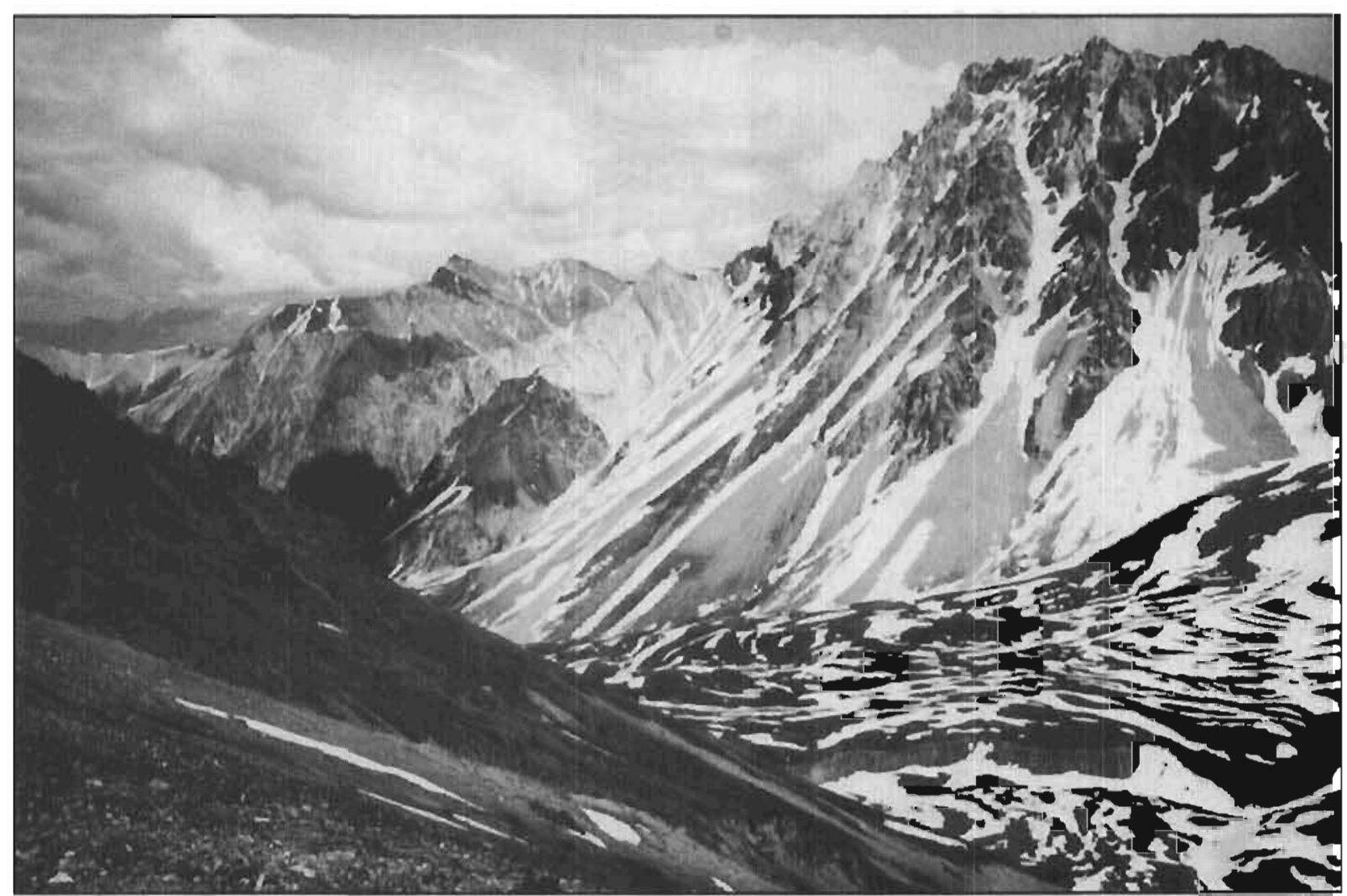

Professional Report 94

Published by

STATE OF ALASKA

DEPARTMENT OF NATURAL RESOURCES

DIVISION OT GEOLOGICAL \& GEOPITYSICAL SURVEYS 


\section{GEOLOGY OF THE NORTHERN CHUGACH MOUNTAINS, SOUTHCENTRAL ALASKA}

By

L.E. Burns, G.H. Pessel, T.A. Littlc, T.L. Pavlis, R.J. Newberry, G.R. Winkler, and John Decker

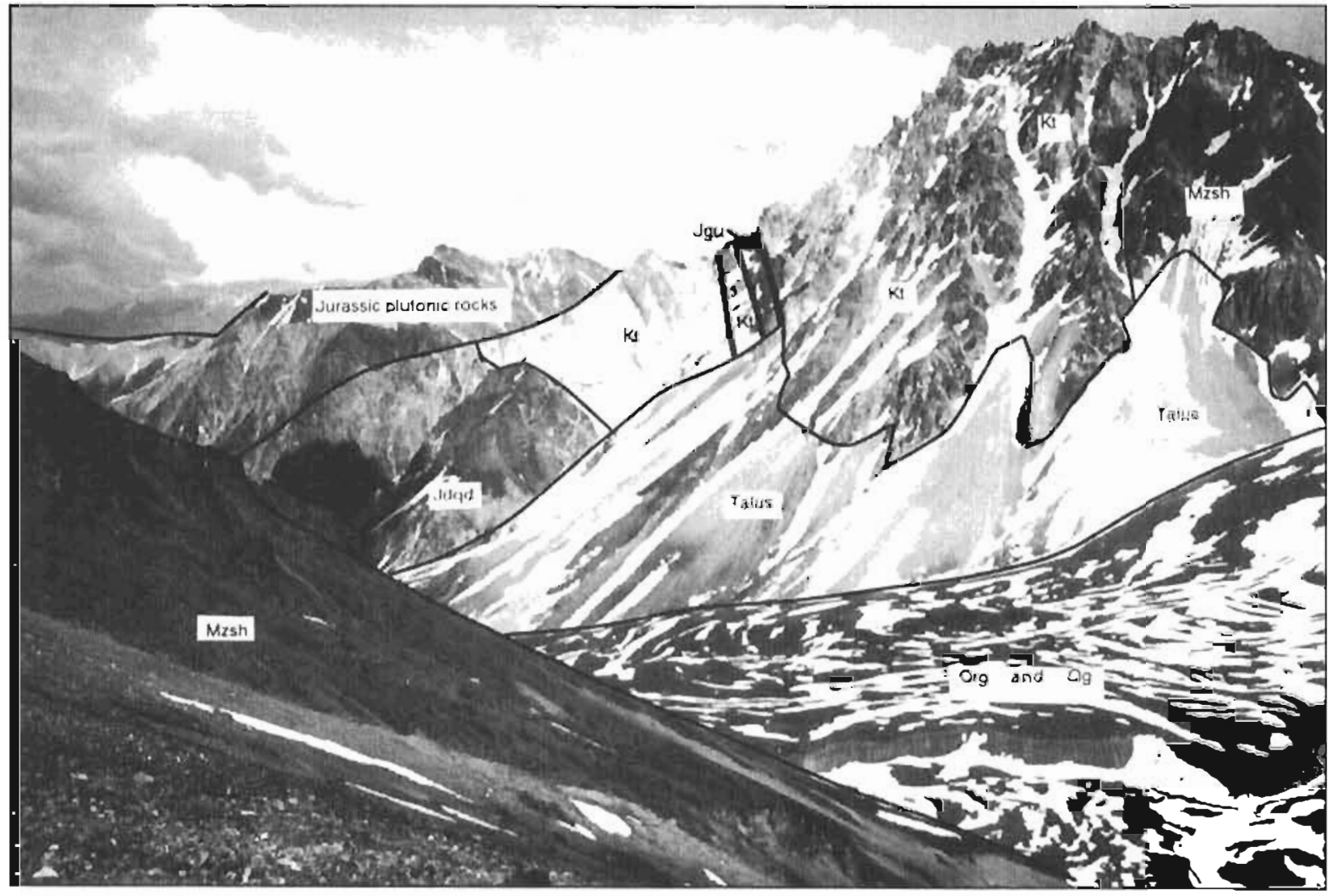

Cover: View looking east into valkey of a miburary of Coal Creck in the Anchorage C-4 Quadrangle. Phow shows Mesozoic schist (MzBh) and a very mired unis of Jurassic diorile-quartz diorike (Jdqd) iniruded by Crelaceous trandhjemike (KI). A small faul-bounded sliver of Jurassic gabbroic racks (Jgu) is imbedded in the rrondhjenuile. A mixure of Jumassic plutonic racks, including compositions from gabbroic 10 guanz dioritic, crops oul in the background. Foreground is composed of a rock glacter (Qra) and glacler $\left(Q_{g}\right)$. Phow by G.H. Pessel. 1983.

Professional Reporl 94 Division of Gcological \& Geophysical Surveys 


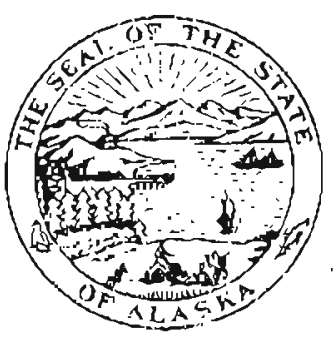

STATE OF ALASKA

Walter J. Hickel, Governor

DEPARTMENT OF NATURAL RESOURCES

Harold C. Heinze, Commissioner

DIVISION OF GEOLOGICAL \& GEOPHYSICAL SURVEYS

Thomas E. Smith, Acting Director and State Geologist

DGGS publications may be inspected at the following locations. Address mail orders to the Fairbanks office.

Alaska Division of Geological \& Geophysical Surveys

794 University Avenue, Suite 200

Fairbanks, Alaska 99709-3645

400 Willoughby Avenue, 3rd floor

Juneau, Alaska 9980 1-1796

U.S. Geological Survey Earth Science Information Center

605 Weat 4th Avenue, Room G684

Anchorage, Alaska 99501-2299

4230 University Drive, Room 101

Anchorage, Alaska 99508-4664

This publicalion, released hy the Division of Geological \& Gcophysical Surveys, was produced at a cost of $\$ 10$ per copy which includes the sext prinicd in Defita Junction, Alaska and the oversize maps which were printed in Washington, D,C. Publication ia required by Alaska Stalute 41, "to determine the potential of Alaskan land for production of melals, minerals,... [and] advarie knowledge of the guology of Alakka." 


\section{CONTENTS}

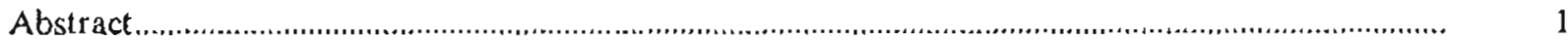

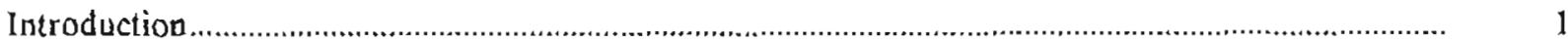

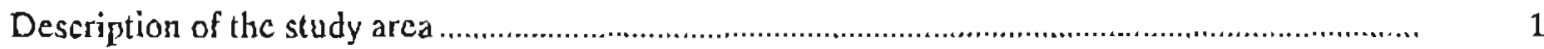

Location, access, and topography..........................................................................................

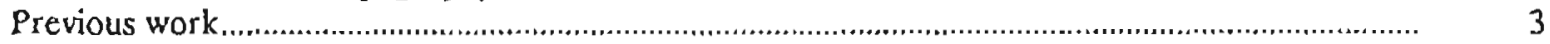

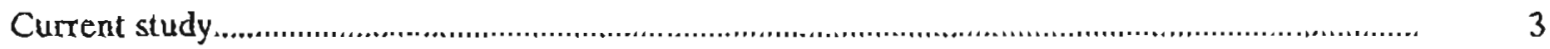

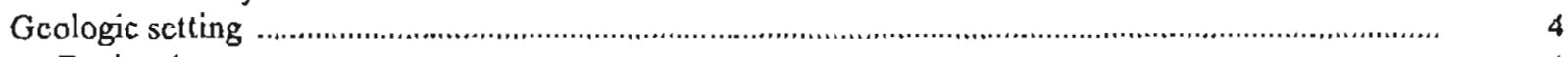

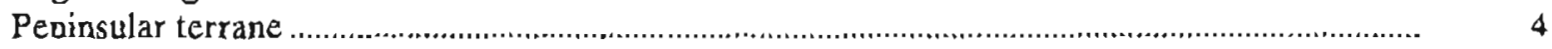

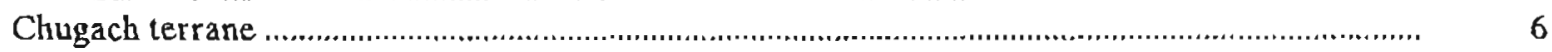

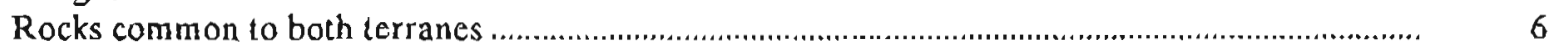

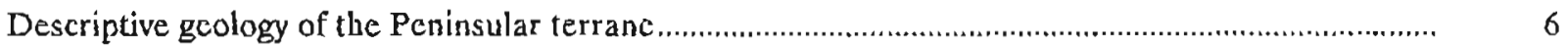

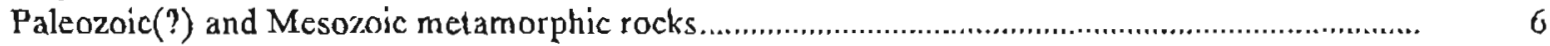

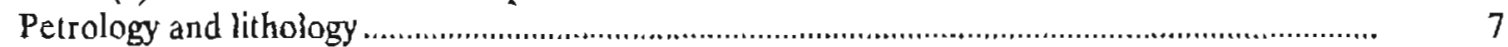

Amphibolite and marble.............................................................................................. 7

Pelitic schist and quartzite.............................................................................................. 7

Mixed assemblages of metamorphic and plutonic rock.......................................................

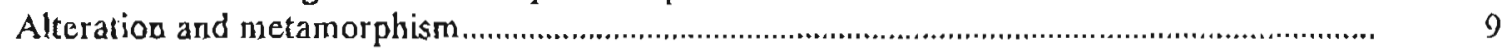

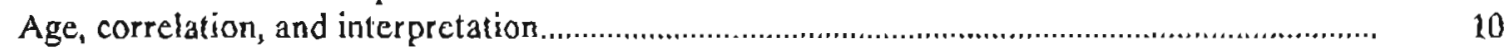

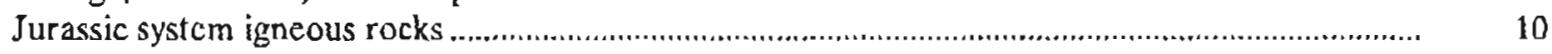

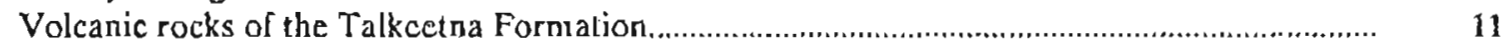

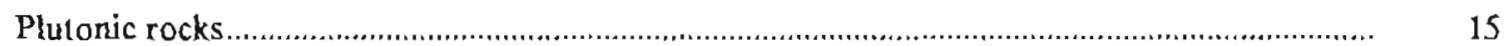

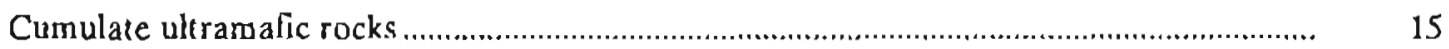

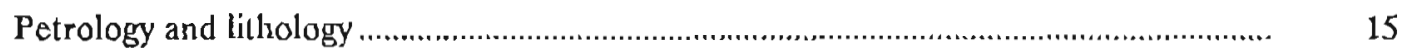

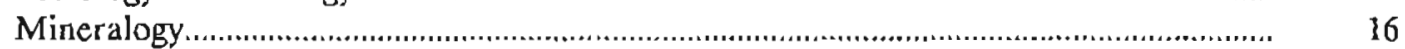

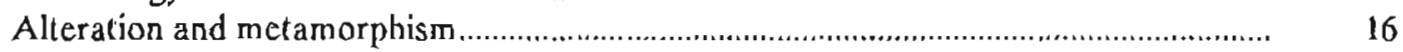

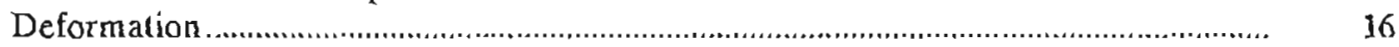

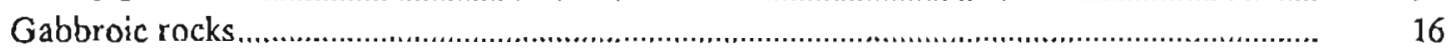

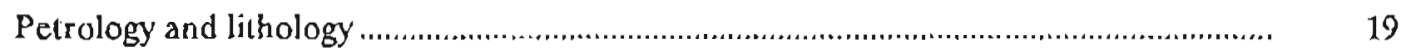

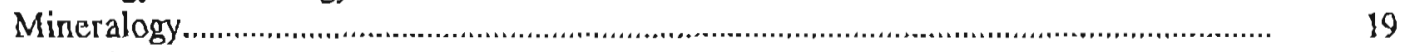

Gabbronorite clan ..................................................................................... 19

Pyroxene-hornblende gabbronorile ................................................................. 20

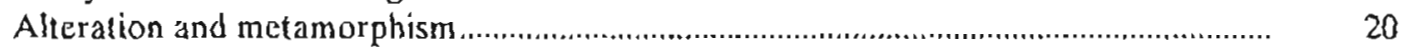

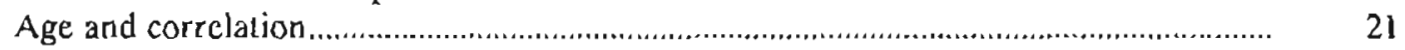

Intermediate composition plutonic rocks ...................................................................... $\quad 21$

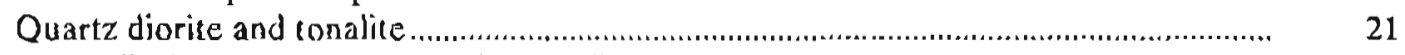

Granodiorite within quartz diorite-tonalitc plutons.......................................................... $\quad 25$

Small phtons of quartz monzodiorite and granodiorite................................................ 25

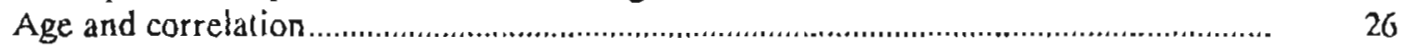

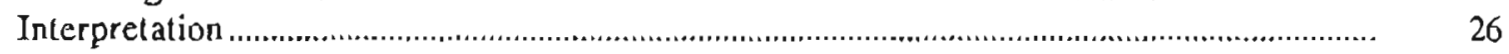

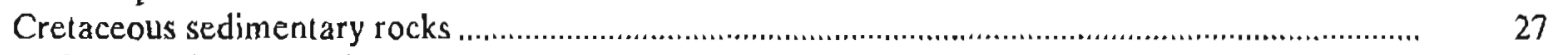

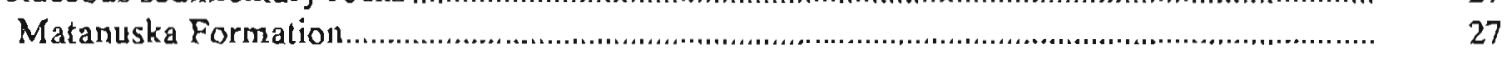

Petrology and lithology ........................................................................................... 27

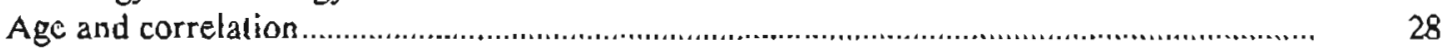

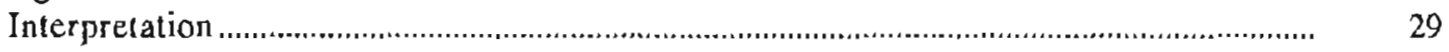

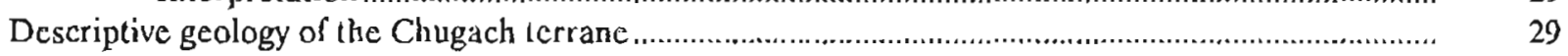

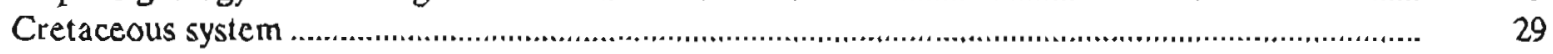

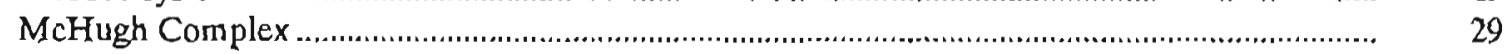

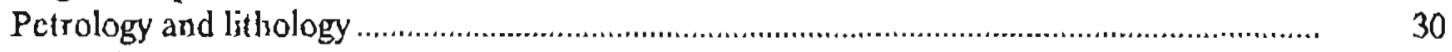

Alteration and metamorphisn ................................................................................. $\quad 30$

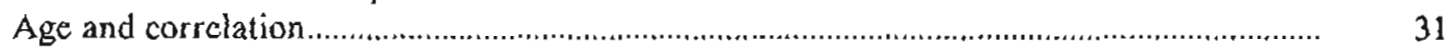




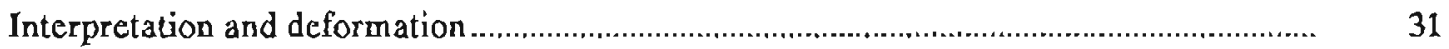

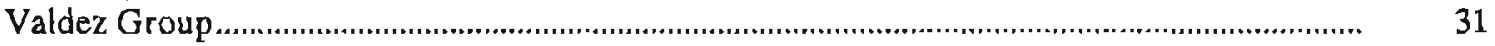

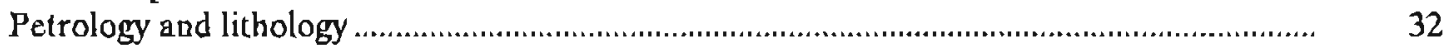

Alteration and metamorphism.................................................................................... 32

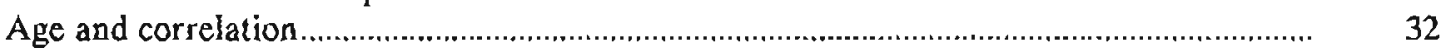

Interpretation and deformation............................................................................... 32

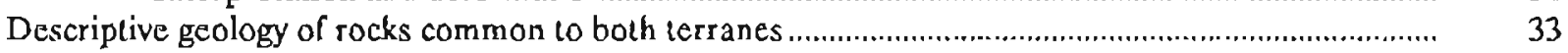

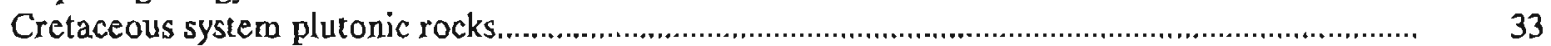

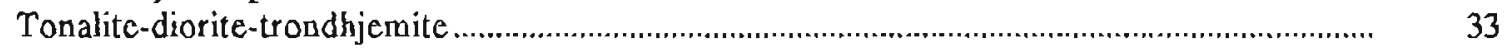

Dikes in eastern part of map area .................................................................................... 33

Plutons in western part of map area .............................................................................. 33

Compositon of both eastern and western trondhjemites ..................................................... 35

Age, correlation, and interpretation.......................................................................... 35

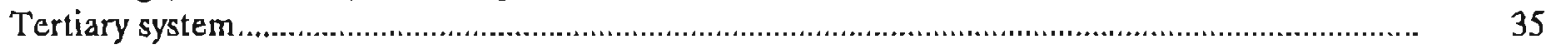

Sedimentary rocks of the Chickaloon Formation.....................................................................

Petrology and litbology ........................................................................................... 37

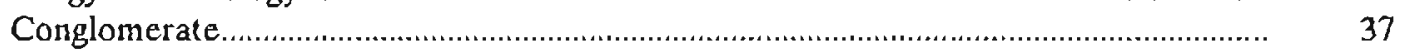

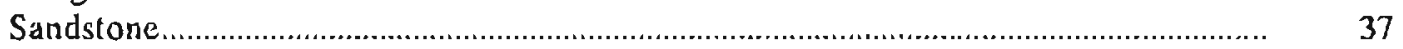

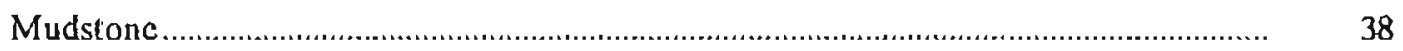

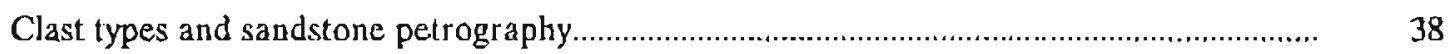

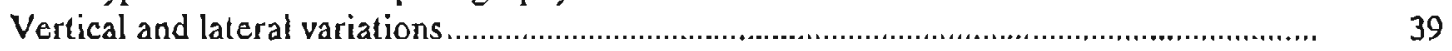

Age and correlation..............................................................................................

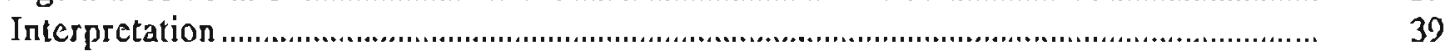

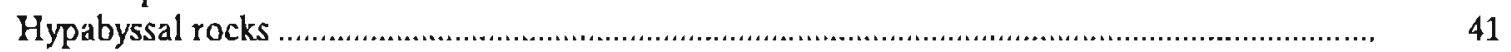

Peninsular terrane felsites ........................................................................................... 41

Chugach terrane felsites ................................................................................................ 41

Age, correlation, and interpretation................................................................................ 43

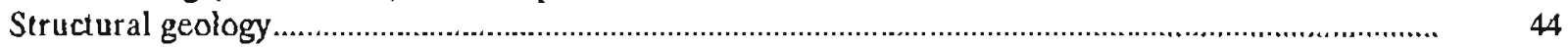

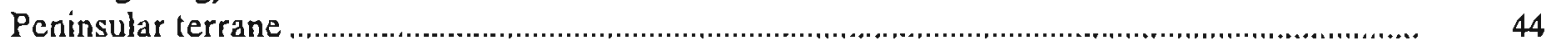

Deformation of dominantly Jurassic age.........................................................................

Metamorphic rocks of dominantly Jurassic age ...............................................................

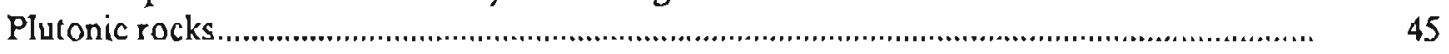

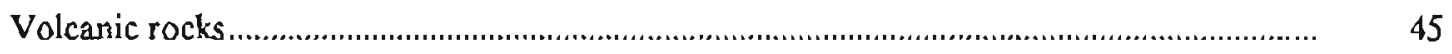

Brittle deformation of probable Early Cretaceous age ......................................................... 46

Uplift, erosion, and northward tilting of post -Jurassic age ................................................... 47

Uplift, erosion, and faulting of latest Cretaceous-carly Eocenc age ....................................... 48

Faulting and folding of post-early Eocene age ..................................................................... 48

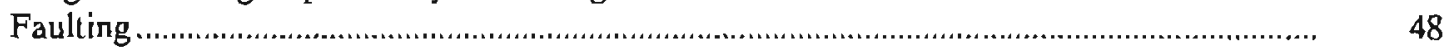

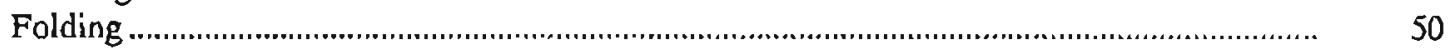

Faulting that postdates intrusion of Late Eocene fetsites ........................................................

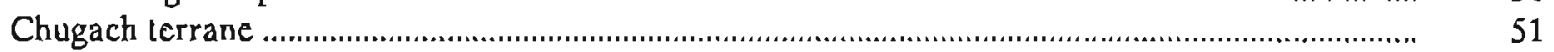

Cretaceous deformation affecting the McHugh Complex ....................................................... 52

Deformation affecting both the McHugh Complex and Valdez Group..................................... 52

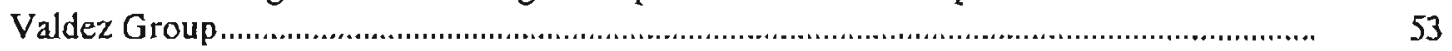

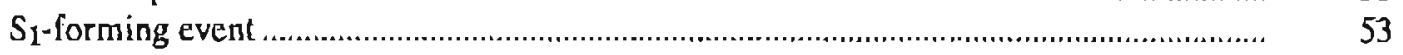

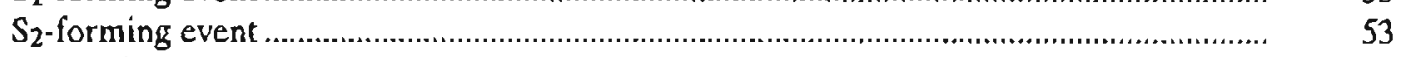

Interpretation .......................................................................................................... 54

Deformation of Chugach terrane rocks similar to that affecting early Eocene and

older rocks in the Peninsular terrane............................................................................ 55

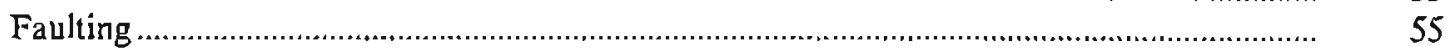

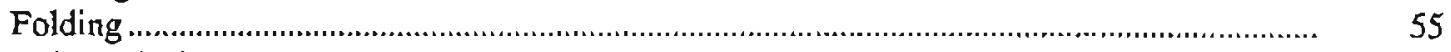

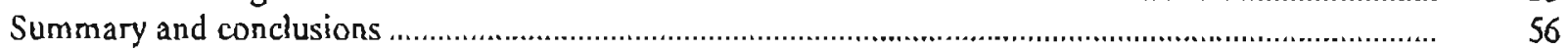

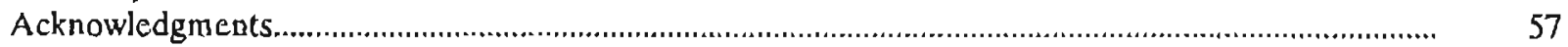

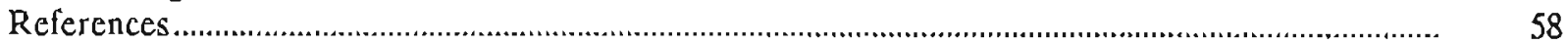




\section{FIGURES}

Figure 1. Location map of southecntral Alaska, showing mountain ranges, major vałleys, and major faults

2. Generalized gcologic map of Nelchina-Kings Mountain region........................................ 5

3. Map of Nelchina-Kings Mountain region showing quadrangle boundaries, Border Ranges fault and major surficial features ........................................................................ 8

4. Harker diagrams for Talkeetna Formation volcanic rocks............................................

5. AFM diagram for Tálkectna Formation volcanic rocks ................................................. 14

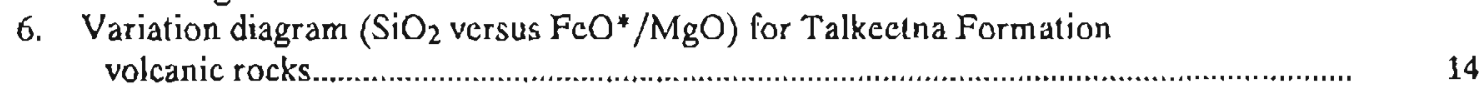

7. Harker diagrams for gabbroic, quartz diorilic, and trondhjemitic rocks from the nortlucentral Chugach Mountains.......................................................................... 23

8. Ternary diagram showing modal pcrcenlages of quartz-plagioclasc-potassiumfeldspar of a quartz diorite-tonalite pluton...

9. Synoptic stereogram of combined poles to schistocily and bedding in prcJurassic metamorphic rocks of the Peninsular torrane

10. Contoured lower-hemisphere equal-arca stercograms of poles to schislosity and lineation in the Cretaceous subduction complex

11. Stylized map sections showing present distribution of McHugh Complex, Pcrinsular terrane, and Valdez. Group and inferred model in central part of sludy area...

TABLES

Table 1. Major-oxide analyses and CIPW norms on volcanic rocks of the Talkeetna Formation...

2. Major-oxide analyses and CJPW norms on gabbroic rocks from the northcentral Chugach Mountains.

3. Major-oxide analyses and CIPW norms on quartz dioritc, fonalite, and granodiorilc from the northcentral Chugach Mountains...

4. K-Ar and U-Pb ages from intermediate composition plutonic rocks of Jurassic agc from the northcentral Chugach Mountains...

5. K-Ar and $\mathrm{U}-\mathrm{Pb}$ ages from Cretaceous tonalite and trondhjemite plutonic rocks of the northcentral Chugach Mountains.

6. Major-oxide analyses and CIPW norms of trondhemite from the northeentral Chugach Mountains.

7. Major-oxide analyses and CIPW norms on hypabyssal rocks of the northcentral Chugach Mountains

8. K-Ar ages from hypabyssal rocks of the northcentral Chugach Mountains.

SHEETS

[In pocket]

Sheet 1. Geologic map of the northern Chugach Mountains, southecntral Alaska (west hall)

2. Geologic map of the northern Chugact Mountains, southcentral Alaska (east hall) 


\title{
GEOLOGY OF THE NORTHERN CHUGACH MOUN'TAINS, SOUTHCENTRAL ALASKA
}

\author{
By \\ L.E. Burns, ${ }^{1}$ G.H. Pessel, ${ }^{1}$ T.A. Little, ${ }^{2}$ T.L. Pavlis, ${ }^{3}$ R.J. Newberry, ${ }^{4}$ G.R. Winkler, ${ }^{5}$ and John Decker ${ }^{6}$
}

\begin{abstract}
The Border Ranges lault systcm juxtaposes the Peninsular and Chugach terranes, and is one of the major structural fealures in southeentral Alaska. This fault sysicm can be craced in an arcuatc paticm from Kodiak island to southcastcrn Alaska along the northem part of the Chugach and Fairweather Mountains. In the northeentral Chugach Mountains, the fault system shows evidence for direct compressional movement between the two terrancs. and younger dextral-wrench movement, similar to that present on the Denali and Castle Mountain fault systems.

The Peninsular terrane crops out to the north of the Border Ranges fault system and is composed of the plutonic core and cxtrusive portions of an intraoceanic island arc of Jurassic age and younger sedimentary rocks. The Chugach terrane to the south is composed of trench-fill and trench slope deposils of largely Cretaccous age.

The geologic mapping described in this report suggests that mafic and ultramafic rocks of the island are intruded upper Patcozoic(?) metavolcanic and mctasedimentary rorks at moderately high pressures (15 to $30 \mathrm{~km}$ oeph). Much multiplc diking occurted, although large chambers of magma may also have been present. The malic and ullramalic rocks formed a considerable thickness, possibly $10 \mathrm{~km}$, by the and of arc activity. Fractional cryslatlization and venting of the malic magmas probably produced much of the volcanic rock associated with the overdying Talkeelna Pormation volcanic rocks. Largc plutons of intermediarc composition began intuding the mafic plutonic rocks before all gabbroic rock had compleicly cooled. The inlermediate rocks crop out discontinuously from near Tonsina lo near Kodiak Island. The intermediate rocks ate similar to those in the Talketna-Aleutian Range batholith, and may be an edge of that
\end{abstract}

${ }^{1}$ Alaska Division of Geological and Gcophysical Surveys, 3700 Airpore Way, Fairbanks, Alaska 99709-4699.

2 Department of Geology, University of Qucensland. St. Lucia, Queensland, Australia 4072.

${ }^{3}$ Department of Geology-Geophysics, University of New Orleans, New Orleans, Louisiana 70148.

${ }^{4}$ Depanment of Geology, Universily of Alaska, Pairbanks, Alaska 99775.

$5^{5}$ U.S. Geological Survey, MS 905, Box 25046, Federal Center, Denver, Colorado 80225-0046.

${ }^{6}$ Arco Alaska Inc., P.O. Box 100360, Anchorage, Alaska 79510 0360. batholith. The intermediate rocks also occur as dike complexes in the Chugach Mountains.

The istand are became exlinct by about Middle Jurassic sime. Uplift and erosion produced an unconformily belween the 'Talkectna Formation and the overlying Cretaccous Malanuska Formation, a sequence of marine sedimentary rocks.

Besween Middle Jurassic and late Early Crctaccous time, a convergent margin was formed along the southerm edge of the cxtinct Pcrinsular terrane island arc. Deposition of trench slope deposits, and deformation of thesc scdiments in a subduction wedge, formed the Mcllugh Complex, a subduction melange. Conninued convergent platc mocion pushed the Mellugh Complex bencath the Peninsular terrane rocks, which probably caused uplitl, crosion, and norlhward likting of rocks of ihe Peninsular tcrranc. The underthrusting formed large brictse shcar zones with calaclastic texture. These shear zones and inferred thrusts arc part of the original Border Ranges fault system.

In latest Cretaccous - Palcocene time, continued convergence and scdiment deposition caused thruse emplacement of the Valdez Group, a thick sequence of trench fill deposits. bencalh the Mclugh Complex and deposilion of the Matanuska Formation ceased because of uplifs of the Peninsular and Chugach tcrranes, South-side-up block faulling within the Border Ranges fault system was followed by deposition of humid-climate, alluvial fan scdiments of the Chikaloon rormation.

In post-Early- to pre-late Locene lime, the Border Ranges fault system was activated as a oextral strike-slip fault zone, prior to intrusion of widely distributed Eocene feisjtc dikes. No nore than a few icns of kiloncters of dextral-slip accumulated during this faulting cvent. The youngest rocks in the area are felsite and basallic dikes of mid- 10 late Eocene age which are common throughout bolh terranes in the map area and locally intrude the faulled boundary between these terranes. Movement on the Border Ranges fault system has probably been minor since inlrusion of these dikes in late Focene lime.

\section{INTRODUCTION}

\section{DESCRIPTION OF THE STUDY AREA}

The arca mapped in this sludy, the Nelchina-Kings Mountain region, lies within the northern Chugach Mountains in southeentral Alaska (fig. 1). The 


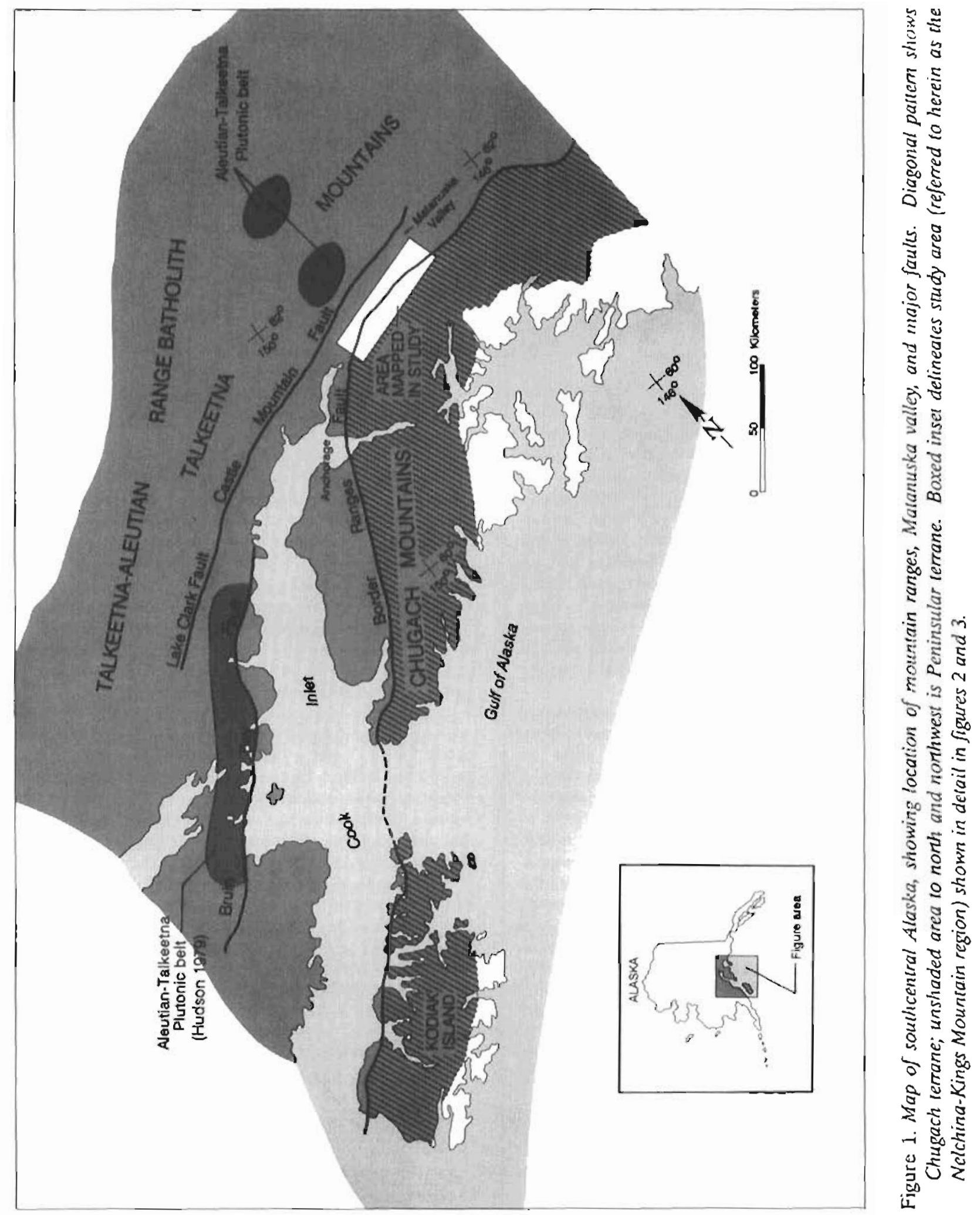


Border Ranges fault system crosses the region and juxtaposes two geologic terranes: the Peninsular tcrrane, composed of the plutonic core and extrusive portions of an intraoceanic island arc of Jurassic age and younger sedimentary rocks; and to the south, the Chugach terranc, composed of highly deformed trench-fill, trench-slope, and ocean-basin deposits largely of Cretaccous age (fig. 1).

The almost continuous exposure in the Nelchina-Kings Mountain region allows detailed cxamination of the processes that formed the magmatic part of an island arc and the faulting along major convergent plate margins. This report concentrates on the plutonic rocks of the Jurassic island arc, Cretaccous and Tertiary sedimentary rocks, and post-Jurassic structural events.

\section{LOCATION, ACCESS, AND TOPOGRAPHY}

The Nelchina-Kings Mountain region lies between the Nelchina Glacier on the east and the Knik River on the west; the region is bounded on the north by the Matanuska Valtey, a structural depression that separates the Chugach and Talkeetna Mountains (fig. 1). The region name was chosen from geographic landmarks; no geologic boundaries are associated with its edges. The region lies entirely within the Anchorage Quadrangle.

The Nelchina-Kings Mountain region is roadless and generally inaccessible except by aircraft. A few fixed-wing landing sites are located on sandbars along the major streams in the arca, but best access is by helicopter. There are some trails in the castern and western parts of the area that are used by guided hunting parties with pack horses.

Topography in the Nelchina-Kings Mountain region is extremely steep. Mountains with thousands of feet of relief are incised by decp glacial valleys and steep-sided stream-cut gorges. Most of the major streams have their source in glaciers descending from ice fields in the core of the Chugach Mountains. Glaciation occurred over much of the area as recently as late Pleistocene (Reger and Updike, 1983); moraines, cirques, horns, and other glacial features are common.

\section{PREVIOUS WORK}

Geologically, the Nelchina-Kings Mountain region was relatively unexplored prior to 1979 . G.C. Martin (1926) and S.R. Capps (1927) performed early reconmaissance exploration in the Matanuska Valley and along the edges of the Chugach and
Talkeetna Mountains. F.F. Barnes and Arthur Grantz of the U.S. Geological Survey conducted extensive detailed mapping northeast of the map area in the 1950s and 1960s, respectively (Barnes and Payne, 1956; Grantz, 1960a,b,c, 1961a,b, 1964, 1966; Barnes, 1962; Grantz and others, 1963). Part of their mapping along the northernmost edge of the Chugach Mountairs has been modified and incorporated into this report. S.H.B. Clark $(1972 a, b)$ mapped in the arca of the Wolverine ultramafic complex in 1970; Clark's map has been modified and is also incorporated. George Plafker of the U.S. Geological Survey had obtaincd some scattered data between Glacier Creek and the Nclchina Glacier, while working on a study of the regional extent of the Border Ranges fault system during 1973-75, and very kindly furnished his unpublisbed fiekd maps to us when we started work in the Nelchina-Kings Mountain region in 1979.

\section{CURRENT STUDY}

The geologic mapping in this report is a compilation of field work done over the 5-yr period from 1979 to 1983 by a team of geologists. The U.S. Geological Survey (USGS) and the Alaska Division of Geological and Geophysical Survcys (DGGS) have cooperated on an informal basis in the Nelchina-Kings Mountain region since DGGS started work in the Chugacb Mountains in 1979. Although geologic mapping was continued on a limited basis in 1980 and 1981, most of the work in the study area was done during 1982 and 1983, with helicopter support.

In 1981, the USGS started its Alaska Mineral Resource Appraisal Project (AMRAP), which involved 1:250,000-scale mapping in the Anchorage Quadrangle (Winkler, 1990), while DGGS was doing detailed mapping at a scale of 1:25,000 in the northern Chugach Mountains. Geologists from botb organizations worked together on an informal basis in parts of the area, sharing information, ideas, and logistical support; the geologic map of the current report is simplified and reproduced in the Anchorage AMRAP map (Winkler, 1990). Detailed geologic maps published as a result of this study include Pessel and others (1981), Burns and others (1983), Pavlis (1986), Little and others (1986b), and Burns (in press).

Several graduate theses and mineralization studies on the northern Chugach Mountains have been done as a result of this study. These include work by Burns $(1981,1983)$ on Jurassic plutonic rocks, Pavlis (1982a) on Mesozoic structural geology, 
McMillan (1984) on Jurassic volcanic rocks, Monteverde (1984) on Cretaceous plutonism, Serfes (1984) on amphibolites of the wasterr Chugach Mountains, and Litle (1988) on Tertiary structural gcology. R.J. Newberry, under contract to DGGS, conducted an in-depth study of mineralization in the northern Chugach Mountains (Newberry, 1986).

\section{GEOLOGIC SETTING}

The northern Chugach Mountains comprise the plutonic core and cxtrusive portions of an intraoceanic island arc of Jurassic age juxtaposed with faulted subduction complex rocks, principally of Crelaccous age, to the south. The island arc rocks compose part of the Peninsular terrane, and the accreted rocks compose the Chugach terrane (fig. 1). The two contrasting terrancs are juxtaposed along the Border Ranges faukt system, which can be traced in an arcuate pattern along the northern part of the Chugach and Fairweather Mountains, from Kodiak Island to soulheastern Alaska. The term Peninsular terrane as used hercin also includes Cretaceous sedimcntary rocks north of the Border Ranges fault that werc derived from the Jurassic arc.

\section{PENINSULAR TERRANE}

Rocks formed in a Late Triassic(?)-Early Jurassic island are constitute most of the Peninsular terrane of Joncs and others (1981). This terrane extends in discontinuous outcrops from the Talkectna Mountains and northern Chugach Mountains to the present-day Alcutian Arc on the Alaska Peninsula. A fault-bounded slice of island arc rocks ranging from 2 to $15 \mathrm{~km}$ in width crops out between the Border Ranges fault system and the Matanuska Valiey. The arc sequence consists of the Talkeetna Formation, ultramafic and gabbroic rocks, and intruding quartz diorite and tonalite plutons. The Talkeetna Formation, largely andesitic and dacitic volcanic rocks and volcaniclastic sedimentary rocks, is Early Jurassic in age. The ultramafic and gabbroic rocks are penecontemporaneous with the volcanic rocks and probably represent the fractional crystallization products of magma(s) which produced the volcanic rocks (Burns, 1983, 1985). A suite of intermediate composition plutonic rocks, including diorite, quartz diorite, tonalite, and minor amounts of granodiorite, intruded mafic and volcanic rocks of the arc sequence during Middle to Late Jurassic time (Pessel and others, 1981; Winkler and others, 1981a,b; Burns and others, 1983; Pavlis, 1983).
These intermediate plutonic rocks may correlate with rocks of the main Talkeetna-Aleutian Range batholith (Hudson, 1979) to the north, as they consist of the same rock types and have similar compositions, ages, and intrusive relationships.

Tectonic deformation in the northern Chugach Mountains bas tilted and faulted the arc sequence of Peninsular terrane, exposing structurally lower arc rocks to the south (Pessel and others, 1981; Winkler and others, 1981b; Burns and otbers, 1983). Allhough faulting is extensive, the gencral stratigraphy of the arc sequence remains intact (Burns, 1985). Cumulate ultramafic and mafic rocks of the Pcninsular terrane are located on the southern edge of the arc sequence and are structurally overlain and intruded by the intermediate plutonic rocks; volcanic rocks of the Talkeetna Formation form the northern edge of the arc sequence and are structurally the bighest unit (fig. 2).

The ultramafic and mafic plutonic rocks probably crystallized near the crust-mantle boundary (Burns, 1985). Tectonized harzburgites with a mantle deformation texture are present south of the cumulate rocks, at the castern edge of the are sequence (Burns 1985; Coleman and Burns, 1985). Minor amounts of harkburgites also occur south of the cumulate ultramafic rocks in the Wolverine complex (fig, 2) (Pavlis, 1983; Newberry, 1986). These harzburgites were intensely deformed during movement of the Border Ranges fault system and may represent mantle rocks.

Matic plutonic rocks of the island arc intrude metavolcanic and metasedimentary rocks of unknown alfnitics (fig. 2) (Pesscl and olhers, 1981; Burns, 1983; Pavlis, 1983). The protoliths of these metamorphic rocks were dominantly mafic volcanic rocks and siliceous sedimentary racks. With the possible exception of the tectonized harzburgites, these metamorphic rocks are the oldest rocks in the Nelchina-Kings Mountain region. Their ages have not been constrained more precisely than prc-Early Jurassic; for this report, they have becn assigned to a Paleozoic-Mesozoic age range. The protolith volcanic and sedimentary rocks were penetratively deformed and mctamorphosed in the greenschist and amphibotite facies during a regional metamorphic eveat, probably as the island arc formed. The metamorphic rocks are of upper amphibolite facies where intruded by the gabbroic rocks of the arc, and of epidote amphibolite facies where intruded by phutons of quartz diorite and tonalite. Extensive retrograde alteration in the epidote amphibolite and greenschist facies of the metavolcanic and metasedimentary rocks is common. The retrograde 


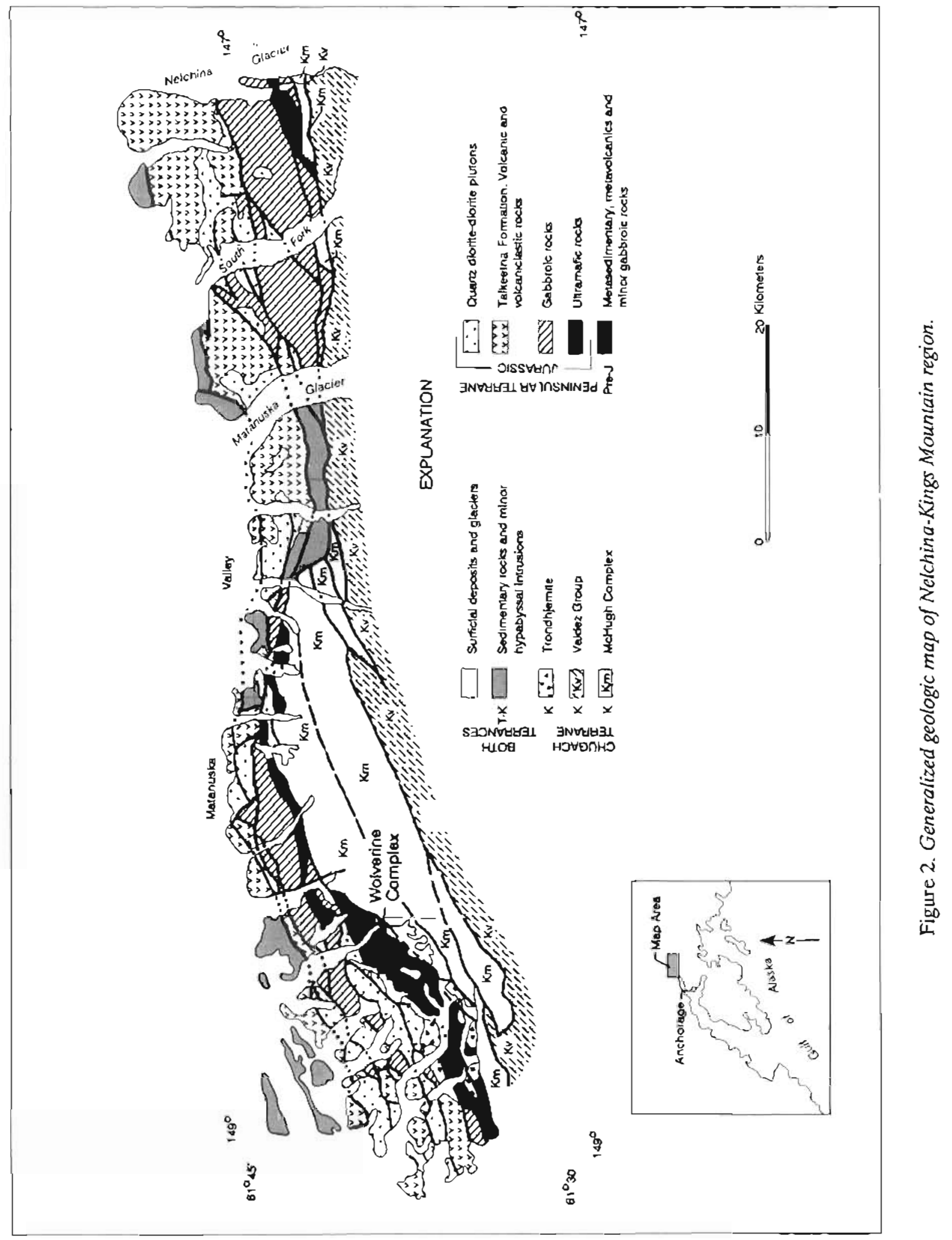


event occurs locally along faults of post-Jurassic age (Pavlis, 1982b) and may be in part related to dispersal of fluids after or during intrusion of the Cretaceous tonalite-trondhjemite plutons.

The Matanuska Formation, a thick sequence of marine sedimentary rocks of Late Cretaceous age, unconformably overlies the arc rocks of the Peninsular terrane (Grantz, 1964). The Matanuska Formation crops out at the northern edge of the Chugach Mountains and consists mostly of mudstonc, siltstonc, sandstone, and pebbly to cabbly conglomerate deposited as turbidites. The formation apparently formed in a fore-arc basin (arc-trench gap) with the clastic detritus derived from erosion of the Jurassic volcanic arc (Grantz, 1964).

\section{CHUGACH TERRANE}

The Chugach terraric crops out in an elongate arc from the Shumagin Islands, about $400 \mathrm{~km}$ soutbwest of Kodiak Island, to southeastern Alaska. The Chugach terrane has been divided into two major lithotectonic units: an older, melange subtcrrane exposed discontinuously along its northern inboard edge, and a younger, deformed flysch subterrane constituting the bulk of the terrane (Plafker and others, 1976). The melange subterrane is known as the McHugh Complex in the Chugach Mountains (Clark, 1973) and the Uyak Formation on Kodiak Island (Connelly, 1978). In the map area, the McHugb Complex is a melange composed of blocks of various ages in a highly deformed matrix of argillite, graywacke, and tuff.

The flysch subterrane is referred to as the Valdez Group and is composed largely of structurally imbricated trench-fill turbidites (Moore, 1973; Plafker and others, 1977). Unlike the McHugh Complex, the Valdez Group is not obviously dismembered but is isoclinally folded and deformed by a penetrative slaty or phyllitic cleavage that generally parallels original layering.

The melange has yielded fossils ranging in age from Permian to middle Crelaceous (Albian) and is locally cut by plutons which yield Early Cretaceous K-Ar age determinations (Pavlis, 1983). The age of the flysch is believed to be latest Cretaceous (Campanian-Maestrichtian) on the basis of K-Ar age determinations (Tysdal and Plafker, 1978; Winkler and others, 1981b). Rocks of the Chugach terrane in the map area are metamorphosed to mineral assemblages typical of the prehnite-purapellyite or greenschist facies.

\section{ROCKS COMMON TO BOTH TERRANES}

Plutons of leucocratic tonalite and trondhjemite yielding Early Cretaceous K-Ar ages intrude both the Chugach and Peninsular terranes in the Anchorage C.4 and C.5 Quadrangles (fig. 2) (Pavlis, 1982a,b, 1983). Because these plutonic rocks cut rocks of both terranes, they constrain interpretation of the structural development of the region. Moreover, their emplacement into the subduction zone assemblage of the McHugh Complex apparently requires "near-trench" plutonism (Marshak and Karig, 1977; Hill and others, 1981; Pavlis and others, 1988).

Hypabyssal dikes and plugs of andesitic to dacitic composition that intruded Chugach and Peninsular terrane rocks during Eocene time (Winkler and others, 1981b; Silberman and Grantz 1984) represent one of the last intrusive episodes in the Nelchina-Kings Mountain region. A few small, undated dikes of basaltic composition cut across the structure and stratigraphy of the map area and are possibly related to the extensive middle Tertiary volcanism in the Talkeetna Mountains to the north (Csejtey and others, 1978). Some mafic dikes in the Matanuska Valley yield late Eocene ages (Silberman and Grantz, 1984).

The Chickaloon Formation of late Paleocene to early Eocene age (Wolfe, 1966; Little, 1988), which consists largely of fluvial sedimentary rocks, unconformably overlies the crystalline and volcanic rocks of the Peninsular terrane and the sedimentary rocks of the Matanuska Formation. The Chickaloon Formation inciudes mudstone, silistone, sandstonc, and conglomerate, as well as coal and carbonaccous sedimentary rocks. The bulk of the Chickaloon Formation overlies the Peninsular terrane, but a small outcrop of nonmarine conglomerate and sandstone, which probably correlates with the Chickaloon Formation, unconformably overlies Valdez Group rocks of the Chugach terrane near the Nelchina Glacier (sheet 2).

\section{DESCRIPTIVE GEOLOGY OF THE PENINSULAR TERRANE}

\section{PALEOZOIC(?) AND MESOZOIC METAMORPHIC ROCKS}

The oldest known rocks in the Nelchina-Kings Mountair region are metasedimentary and metavolcanic rocks of unknown correlation. These 
rocks form a discontinuous east-west-trending belt near the southern margin of the Peninsular terrane, but large screens or roof pendants are also present in the plutonic rocks farther to the norkh. The metamorphic rocks are most abundant in the Anchorage C-4 and C-5 Quadrangles, where they crop out in a belt $3 \mathrm{~km}$ wide (figs. 2 and 3 ).

Three main assemblages of metamorphic rocks occur in the Nelchina-Kings Mountain region. The first, an assemblage denoted as amphibolite (M7a), contains amphibolitc, garnet-bearing amphibolite, and thin $(<0.5 \mathrm{~m})$ marble beds, a few of which are garnetiferous. The protolith of this asscmblage is thought to be a sequence of mafic volcanic rocks (flows?) with small, discontinuous beds of impure limestone and marl. The second assemblage (M7sh) is a heterogeneous asscmblage composed of siliceous schist, pelitic schist, semipelitic schist, mafic schist, and minor amounts of amphibolite and marble. These rocks are interpreted to be metachcrt, metagraywacke, metatulf, meta-pillow basalt, and argillaceous limestone. The third asscmblage (Mzop) is an undifferentiated unit of metamorphic rocks of the first two assemblages, complexly intruded by Jurassic gabbroic and(or) quartz dioritic rocks.

\section{PETROLOGY AND LITHOLOGY}

\section{Amphibollte and Marble}

Sequences of amphibolite (Mza) commonly cxcecd $0.5 \mathrm{~km}$ in structural thickness and contain minor marble and calc-silicate rocks. In most of the Nclchina-Kings Mountain region, these amphibolites are characterized by gncissic textures, grossularitic garnet layers, and a few thin beds of siliccous marblc (probably representing recrystallized argillaccous limestones). In the westcrn half of the Anchorage C-5 Quadrangle, the amphibolites are tinc-grained greenstones with a wcak foliation. Many of the amphibolitic rocks show a thin $(1$. to $3 \mathrm{~cm})$ compositional banding of lighter (plagioclase-rich) and darker (hornblende-rich) layers. Calc-silicate marble crops out in distinct layers and in lenses tens of meters thick. Garnet-rich marble layers are usually $<1 \mathrm{~m}$ thick and can be traced discontinuously for $200 \mathrm{~m}$ or more (gencrally the length of an outcrop).

Contacts between the amphibolitic rocks and the intrusive gabbroic rocks are well exposed ncar the Nelchina Glacier (Burns, 2983, in press) and in the Anchorage C.4 Quadrangle (figs. 2 and 3). Host metamorphic rocks in contact areas are granofelsic and consist of thinly layered $(0.5$ to $10 \mathrm{~cm})$ plagioclase-hornblende-quartz, plagioclase-clinopyroxene, garnet-clinopyroxene-calcite \pm quartz, hornblendeplagioclase-biotice \pm garnet rocks, and garnet-pyroxene skarn. The prescnce of metasomatic skarn is indicated by garnets with anisotropic rims, by the prograde reaction of garnet-clinopyroxene formed directly from clinopyroxenc-plagioclase layers, and by veins of garnet.

\section{Pelitic Schist and Quartzite}

Fault-bounded sequences of pelitic and siliceous schist (presumably metamorphosed siliceous argillite and ribbon chert) with lesser amounts of quartzolcldspathic schist (mctagraywacke and/or metatum) and minor amounts of mctamorphosed marl, bintitealbite amphibolite, and garnet amphibolite (Mzsh) occur in the Anchorage C-3, C-4, and C-5 Quadrangles (figs. 2 and 3). Most of these metamorphic rocks weather dark red-brown. In the western third of the Anchorage C-5 Quadrangle (near Jim Crcek), siliccous schist grades into a lower-grade sequence, where the protolith is clearly chert with interbedded siliccous argillite. Within this unit, coarse-grained amphibolite is transitional into upper greenschist facics greenstones, which are wcakly foliatcd. These rocks probably include both metatuff and pillow basalt (Pavlis, 1983) and have been described in detail by Pavlis (1986) and Litle and others (1986b).

Siliceous and pelitic schist is generally thinly laycred. 1solated, thick (10 $10 \mathrm{~m}$ ) layers of amphibolite are interleaved with the quarte-rich schist. Siliceous schist and quartzite are fine-graincd and contain 75 to 98 percent granoblastic-polygonal quartz Locally the schist is strongly foliated. Most schist contains 4 to 15 percent lepidoblastic redbrown biotic, about 2 percent magnetite and hematite, and about 1 percent euhcdral garnct; many samples contained as much as 7 percent white mica. Garnet is usually concentrated along pelitic layers, where it makcs up as much as 20 percent of the layers. Minor amounts of plagioclase and(or) subhedral clinozoisite are present in some rocks. Retrograde metamorphism (post- $S_{1}$ ) of the schist is represented by a late generation of chlorite \pm cpidote and by late stage veins of chlorite, carbonate, prehnite, datolite, and quartz. Pelitic schist, commonly graphitic and locally calcareous, is darker than the siliceous schist and contains muscovite, biotite, quartz, garnet, \pm plagioclase. Typically, very thin, siliceous laminae (chert beds) are transposed subparallel to the strong schistosity $\left(S_{1}\right)$. 
Fine-grained quartzo-feldspathic schist is less common than pelitic schist. The protolith of the quartzo-fcldspathic rocks was probably graywacke, tuff, or a combiuation of both. Compositional layering in these rocks probably represents original bedding. The schists are interbedded and (or) interlayered with thin to thick (1 to $10 \mathrm{~s}$ of cms) units of pelitic schist and lesser amounts of epidote amphibolite. The semi-pelitic schist typically contains 15 to 30 percent very palc green amphibole (actirolitc?) needles which are commonly acmatoblastic. Very fue grained granoblastic plagioclase composes 30 to 60 percent of the rock. Most rocks also contain a small amount of rclatively coarse, twinned plagioclasc grains (oligoclaseandesine). Lepidoblastic biotite and chlorite compose 10 to 20 percent of the semi-pclitic schist; quartz, magnetite, titanite (sphenc), clinozoísileepidote, carbonate, and white mica arc minor constiluents. The icxure of the semi-pelitic schist is generally strongly loliated and ocmatoblastic with fine compositional lamination subparallel to the foliation $\left(S_{1}\right)$. Locally, the texturc is isotropic, suggesting that the metamorphic recrystallization postdated or outpaced the deformation.

In the Anchorage C-5 Quadrangle (fig. 3), discontinuous bodies of dark-brown- to reddish-brownwcathering mafic schist are almost as abundant as the siliceous schist (Pavlis, 1986). In the Anchorage C-4 Quadrangle, mafic schist is less abundant (Little and othcrs, 1986b). Its composition is basaltic; it thus prcsumably represents part of a volcanic complex Compositional variations include (1) calcsilicate-bearing "banded amphibolite," in which normal hornblende-cpidote-plagioclase amphibolite is intcrlayered with diopside-zoisitc-garnet rock, and (2) biotic-hornbiende (garnot) amphibolite. The former may be unusual metamorphosed marl or malic tuff interlayered with carbonate; the latter, andesitic and basaltic volcanic rocks or volcanogenic graywacke. The mafic schist varies markedly in texture, depending upon composition and metamorphic grade. Lower-grade (upper greenschist facies) rocks aear Jim Creek consist of massive grecnstone with widely spaccd (to $10 \mathrm{~m}$ separations) domains of weakly developed foliation. Typically, however, the amphibolite cxhibits modcrately developed calaclastic foliation with a weakly to moderately devcloped down-dip lineation. In thin section, the amphibolite generally shows strong alignment of hornblende with foliation and(or) lincation, but notable exceptions occur in "banded amphibolite" where calc-silicate mincrals are randomly aligned within the calc-silicate laycrs.
Thin, metamorphosed marl layers occur locally and consist of laminated granofels containing plagioclasc, carbonate, tremolite, quartz, chlorite, clinozoisite-cpidote, magnetite, and sphene. Sormc plagioclase crystals are helicitic porphyroblasts.

\section{Mixed Assemblages of Metamorphic and Plutonlc Rock}

Mixcd asscmblages of the metamorphic rocks described above are complexly intruded by gabbroic and toaalitic magmas (Mzmp) in the Anchorage C-4 and C-5 Quadrangles. Most commonly, the mctamorphic rocks consist of amphibolites, some granulites, and minor calc-silicate layers. The minerals produced during intrusion of the Jurassic magmas arc corrclative with those in the pyroxcne and hornblende hornfels facies. Burns (1983, in press) has shown that textural features near the contact areas between gabbroic and metamorphic rocks exhibit critcria for catazonal intrusions as defined by Buddington (1959), such as (1) mediumto high-grade couniry rocks, (2) absence of sharp contacts, (3) extensive concordant magmatic border zones, and (4) apparent syntectonic flow. In these arcas of complex intrusion, typical plutons consist of gneissic pods and lenses separated by screens of metamorphic rock in which fabric is concordant with that of the gabbroic gneiss (Burns, 1983, in press). Similar field evidence was observed near mixtures of the quarty diorite and metamorphic rocks (Burns and others, 1983; Pavlis, 1986; Little and others, 1986b). These textural features indicate that the environment of intrusion, particularly that of the gabbroic magma, was deep (15 to $25 \mathrm{~km}$ ).

\section{ALTERATION AND METAMORPHISM}

The metamorphic rocks have becn subject to at least two periods of metamorphism. The first rccognizable event occurred in the Jurassic, synchronous with are plutonism. Schist from a probably correlative sequence of rocks in the Anchorage B-6 Quadrangle yielded a K-Ar age of $173 \mathrm{Ma}$ (Carden and Decker, 1977), and quartz diorite that cuts metamorphic rocks in the Anchorage C-5 Quadrangle yielded an Early Jurassic (195 Ma) K-Ar age on hornblende (Pavlis, 1983). The peak metamorphic facies produced were (1) amphibolite and (2) pyroxene and hornblende granulites (or pyroxene and hornblende hornfels). Whether some metamorphism occurred as a regional event before intrusion of the Jurassic magmas, or whether all metamorphism occurred during arc 
formation, is not clear. Pavlis (1983, unpubl. data, 1985) reports that some of the metamorphic rocks were deformed prior to emplacement of the Jurassic plutons and peak metamorphic conditions.

Retrograde metamorphism occurs adjacent to post-Early Jurassic faults and is more widespread in the western part of the Nelchina-Kings Mountain arca than in the eastern part. The metamorphic grade attained is greenschist and, less commonly, lower amphibolite lacies. During the retrograde metamorphism, clinopyroxene was replaced by quartz-calcite-chlorite \pm pyrite, and partial replacement of garnel and plagioclase by epidote, clinozoisite, chlorite, calcite, and minor pyrite is common. Hornblende is replaced by actinolite. Rocks in the center of fault zones commonly contain abundant prehnitc.

Much retrograde alteration may be Cretaceous in age. Two K-Ar age determinations on hornblende from retrograde mctamorphic rocks in the Anchorage C-5 Quadrangle were 121 and $107 \mathrm{Ma}$ (Pavlis, 1983). These rocks are considered by Pavlis (1986) to be a distinct assemblage, the "Knik River terrane" (sec footnote: Age, Correlation, and Interpretation section).

\section{AGE, CORRELA'TION, AND INTERPRETATION}

The age of the protolith of the metamorphic sequence is unknown. The metamorphic rocks arc intruded by Early to Middle Jurassic plutonic rocks; hence, the age of their protoliths is probably preEarly Jurassic. Permian age fusulinids occur in marble from rocks in an equivalent structural position about $40 \mathrm{~km}$ west of the map area near the Eklutna ultramafic complex (Clark, 1972a), suggesting a Paleozoic age.

The Nelchina-Kings Mountain metamorphic rocks may be correlative with Pennsylvanian-Permian age rocks such as the Strelna Formation in the Wrangell Mountains (Plafker and others, 1985), the Skolai Group (Smith and MacKevel, 1970; Mackevell and others, 1978), and the Mankommen Group in the eastern Alaska Range (Richter and Dutro, 1975). They may also be correlative with metamorphic rocks of probable Permian age that crop out on the west side of Cook Inlet (Magoon and others, 1976).

The metamorphic rocks were interpreted to be a subduction complex or Paleozoic or Triassic age by Pavlis (1982c), who argued that mctamorphic rocks in the Anchorage C-5 Quadrangle were an oceanic suite of rocks that had undergone an early britlle, or melange-like deformation, presumably within an accretionary prism. Pavlis (1983) thought that these rocks were then overprinted by metamorphism and penetrative deformation at high tcmperatures and low or intermediate pressures prior to intrusion of Early to Middle Jurassic plutonic rocks.

Although Pavlis (Pavlis and others, 1988) has proposed a differing interpretation,? the other authors of this paper consider all of the crystalline and retamorphic rocks discussed in this section to bc part of the Peninsular terrane.

\section{JURASSIC SYSTEM IGNEOUS ROCKS}

Rocks of Jurassic age consist of three major groups: (1) an upper sequence of volcanic and volcaniclastic sedimentary rocks of dominantly andesitic to dacitic composition (the Talkeetna Formation); (2) a basal part composed of ultramafic and mafic plutonic rocks (the Border Ranges ultramafic and mafic complex [BRUMC] of Burns, 1985); and (3) a slightly younger, middle portion of plutonic rocks of intermediate composition (largely quartz diorite and tonalite). The gabbroic and intermediate composition plutonic rocks intrudc oider Paleozoic(?) and Mesozoic melamorphic rocks discussed above. The quartz diorites and tonalites intrude the Talkeetna Formation also. These three groups are interpreted to represent the intrusive and extrusive phases of a Jurassic magmatic arc.

The arc sequence, though interrupted by faults, is structurally tilted in the northern flank of the Chugach Mountains, its upper parts lying to the north. From south to north, the sequence consists of minor amounts of tectonized uitramafic rocks of mantle origin, cumulate ultramafic rocks, gabbroic rocks, plutons of quartz diorite and conalite, and volcanic rocks. Because of extensive faulting, no single area exhibits a complete transition from

\footnotetext{
${ }^{7}$ Pavlis interprets the southem half of the Jurassic plutonic rocks and part of the metamorphic rocks to be a distinct terrane, the "Knik River terrane," (Pavlis and others, 1988) after teminology introduced by Carden and Decker (1977). In Pavlis's nomenclature, the Krik River terrane would include all fault-bounded bodics of crystalline rock that are not clearly associated with the Talkcclna Formation. This terminology arises from an attempt to distinguish bctween a system where disparate rocks are juxtaposed along a major fault (as in scparate tectonostratigraphic tcrranes) and a system where minor faulting has obscured the primary conlact relationships between bascment and cover (sce Pavlis, 1986, for a discussion). Pavlis also belicucs there are sufficient ambiguities in correlation pithin the belt to justify sepacation into two distinct structural/lithologic betts.
} 
ultramafic to volcanic rocks, but the sequence from mantle rocks to extrusive rocks is shown on the map and can be traced laterally for more than $1,000 \mathrm{~km}$ in southcentral Alaska, from $100 \mathrm{~km}$ east of the map area to Kodiak Island (fig. 1; Burns, 1985).

\section{VOLCANIC ROCKS OF THE TALKEETNA FORMATION}

The Talkeetna Formation (Martin, 1926), a thick sequence of dominantly andesitic flows and luffs with minor amounts of volcanic-derived sediments, crops out on the Alaska Peninsula (Detterman and Hartsock, 1966; Detterman and Reed, 1980), in the Talkectna Mountairs (Grantz, 1960a,b; Csetjey and others, 1978), and along the far northern edge of the Chugach Mountains (Grantz, 1960c, 196ia,b; Winkler and others, 1981b). These rocks are widely considered to represent the volcanic rocks of an intraoceanic island arc (for examplc, Barker and Grantz, 1982), and compositional diagrams from this study support that conclusion (figs. 4,5, and 6).

Because of Mesozoic-Tertiary structural disruption and major lateral variations characteristic of all volcanic arcs, a complcte stratigraphic section of the Talkeetna Formation is not exposed in the Chugach Mountains. However, a composite stratigraphic section for the Talkeetna Formation in the northcentral Chugach Mountains appears to consist of (from bottom to top) about $2 \mathrm{~km}$ of basaltic to andesitic flows and volcanic breccias (Jtb, $\mathrm{Jta}$, more than $2 \mathrm{~km}$ of andesitic to rhyolitic ignimbritic crystal-lithic lapilli luffs, flows, and possible domes (Jta, Jtat, Jth, Jtd), and $3 \mathrm{~km}$ of interlayered aquagene tuffs and marine sedimentary rocks (Jtt, Jts; sheets 1 and 2) (Newberry and others, 1986). This sequence is best exposed in the area between the South Fork of the Matanuska River and the Matanuska Glacier, where an east-dipping sequence of basaltic volcanic rocks and volcanicderived sedimentary rocks crops out (fig. 3). Swarms of basaltic and andesitic dikes also make up an important part of the Talkectna Formation.

Several volcanic centers, spaced approximatcly 10 to $20 \mathrm{~km}$ apart, exist in the region. The stratigraphy of these centers is dominated by flows and coarse breccias. Notable examples appear at Sheep Mountain (Anchorage D-2 Quadrangle), in the arca west of the Nelchina River (Anchorage D-1 Quadrangle), in northeast Anchorage C-2 and D-2 Quadrangles, and east of Ninemile Creek (Anchorage C-4 Quadrangle) (fig. 3). Each center appears to have a somewhat different volcanic sequence; consequently, no single detailed stratigraphic description applies regionwide. Formal subdivision of the Talkeetna Formation has not been attempted, although lichologic variations have been identified on the detailed maps wherever exposure and accessibility allowed (Pessel and others, 1981; Burns and others, 1983; Little and others, 1986b). McMillan's (1984) study of the Sheep Mountain arca provides the most complete stratigraphic information of any for a single volcanic center in the Talkeetna Formation.

The structurally lowermost Talkeetna Formation lithologies exposed in the study region are basaltic to andesitic flows. Unfauled contacts with older units are not exposed; therefore, now thicknesses can only be cslimated. The basal sequence is probably at least $1 \mathrm{~km}$ thick. Fillowed units have not been observed, and sedimentary rocks are apparently not prescot in the lower part of the formation. The rocks are characteristically thick-bedded, massive to vaguely layered, and dark red-brown to dark graygreen. Some hyaloclastic beds may be prescnt, although none have been reliably identified from petrographic obscrvation. The flows are lighter colored and more siliccous upsection, at least in a broad sense, although reversals are common.

The thickest subunit of the Talkectna Formation is in the middle of the formation and consists of andesitic to rhyolitic tuffs, flows, and possible domes. The proportion of tuff to flow varies considcrably along the lateral extent of the Cbugach Mountain front, but the presence of both is characteristic of the subunit. Thickly to massively bedded gray-green porphyritic andesite is generally the predominant constituent. Most conspicuous, however, are the tuff breccia beds, 5 to $30 \mathrm{~m}$ thick, that consist of $0.2-$ to 2-m-diam blocks suspended in a voleaniclastic matrix, and the siliceous crystal-lithic (ignimbritic) tuffs. Tuff breccias are common near the base of the middle subunit, whereas ignimbritic tuifs are present near its top. The ignimbritic tuffs are pale grcen and contain variable proportions of broken phenocrysts (principally plagioclase and pyroxene) and lapilli-size lithic fragments. These tuffs range from dacitic to rbyodacitic in composition. The thickness of ignimbritic tuffs reaches a maximum of 2 to $3 \mathrm{~km}$ near Mount Wickersham (fig. 3), suggesting that some explosive volcanism centered in that area. The ignimbritic tuffs are commonly interbedded with 1 to 10-m-thick andesitic sills or flows, which suggests that several explosive events took place; small $\left(<0.1 \mathrm{~km}^{2}\right)$, lenticular masses of rhyolite also occur structurally above the ignimbrite. Basaltic to andesitic flows commonly cap the ignimbrites; this relationship is best exposed on Sheep Mountain (fig. 3). 

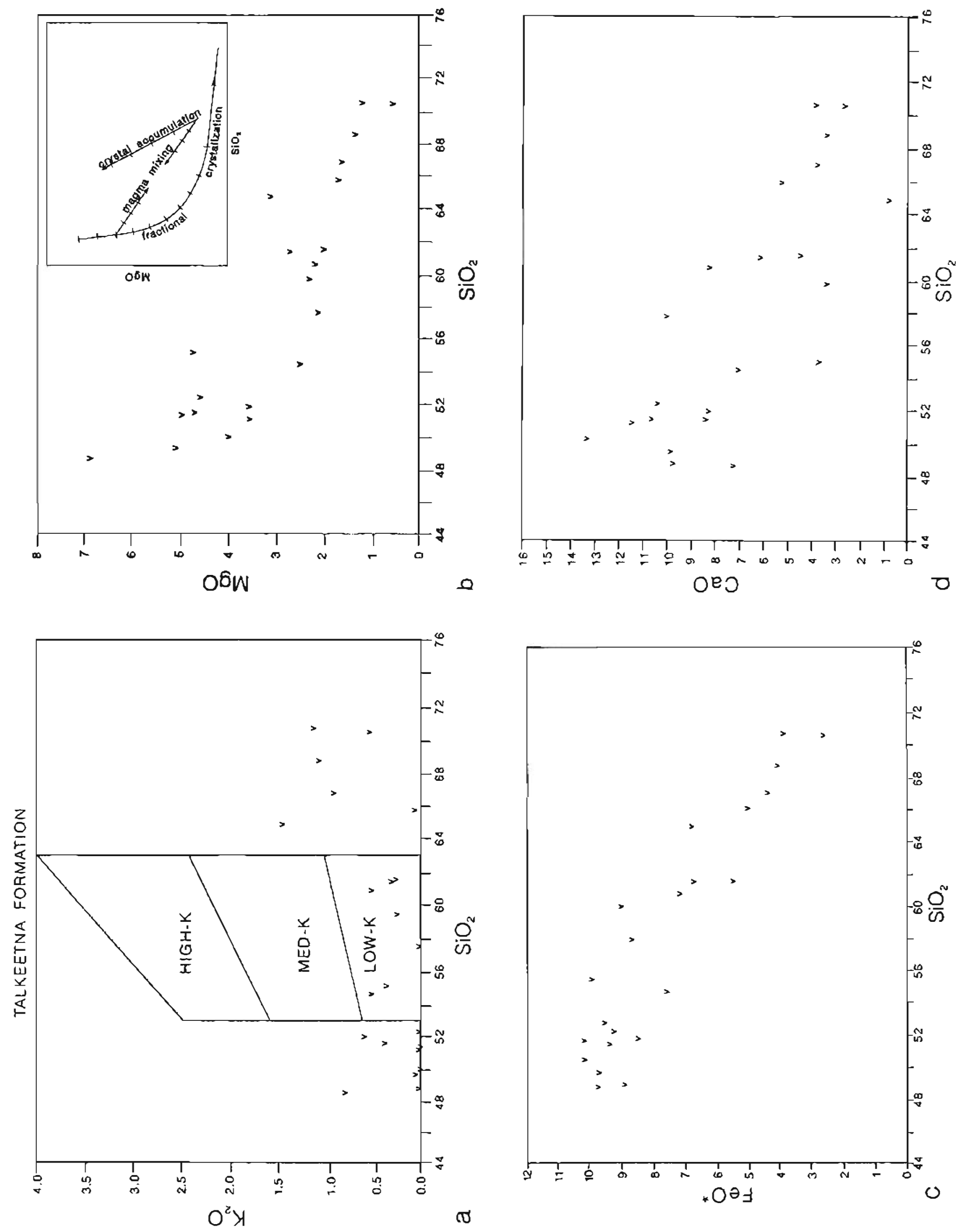

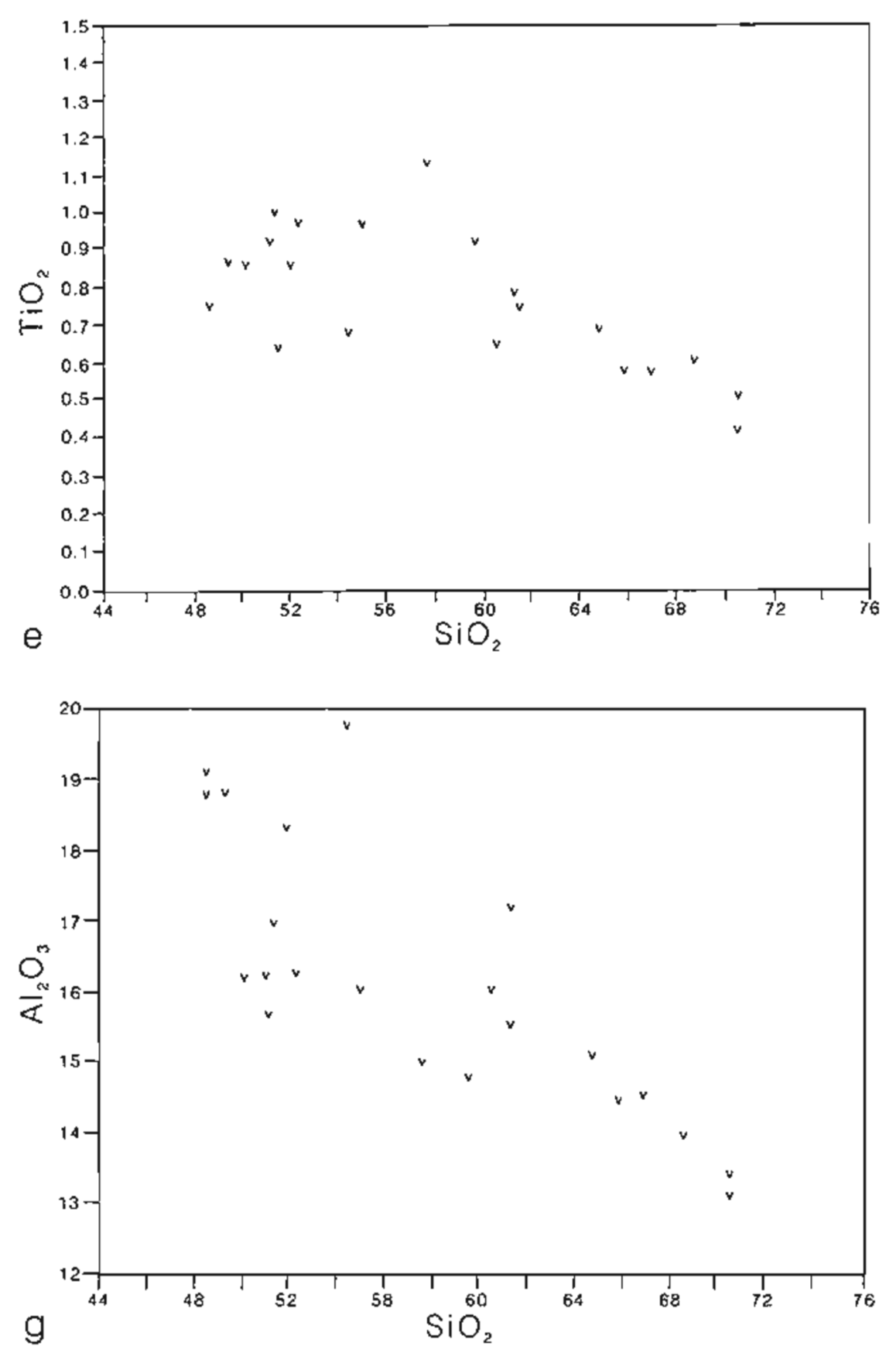

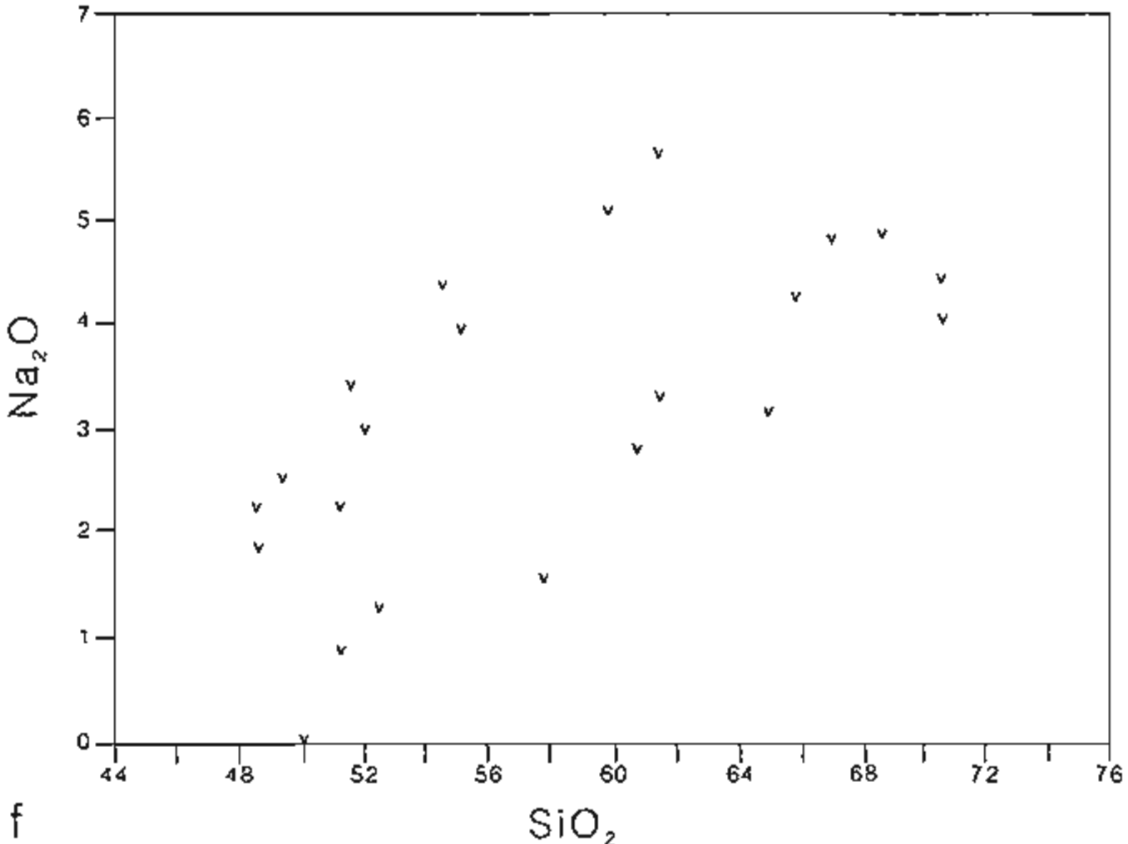

Figure 4. Harker diagrams showing $\mathrm{SiO}_{2}$ plotted against (a) $\mathrm{K}_{2} \mathrm{O}$, (b) $\mathrm{MgO}$, (c) $\mathrm{FeO}^{*}$, (d) $\mathrm{CaO}$, (e) $\mathrm{TiO}_{2}$ (f) $\mathrm{Na}_{2} \mathrm{O}$, and (g) $\mathrm{Al}_{2} \mathrm{O}_{3}$ (all in weight percent) for rocks of the Talkeetna Formation. High- $K$, medium-K, and low-K andesite fields for $\mathrm{K}_{2} \mathrm{O}$ plot from Gill (1981). Cunve for $\mathrm{MgO}$ plot calculated using the Rayleigh fractional crystallization equation where $D_{R b}=0.03, C_{R b}=7 \mathrm{ppm}, D_{M g O}=2.2$, and $C_{M g O}=10.0$ weight percent. Tick-marks indicate 10-percent intervals. 
Volcaniclastic sedimentary rocks compose the upper member of the Talkeetna Formation. These rocks are thin- to medium-bedded, sparsely to abundantly fossiliferous, and include light-gray-green to black graywacke, sandstone, and mudstone. They are distinguished from overlying formations by their less friable character, their greater variability, and the presence of zcolite minerals. An especially prominent lithology is a pale, very thinly bedded, moderatcly well sorted arkosic sandstone (water-laid tur??) with 10 to 20 percent lithic fragments. Contacts between the upper member and underlying lithologies are gradational. The lower part of the upper member commonly consists of a sequence about $1 \mathrm{~km}$ thick of interbedded andesites and sedimentary rocks, capped by several kilometers of voleaniclastic sedimcntary rocks with no volcanic rocks. In a few locations in the Nelchina-Kings Mountain region, depositional contacts with the overlying Cretaceous sedimentary scetion have been observed; additionally, an unconformable upper contact with the Tertiary Chickaloon Formation has been mapped near Ninemile Creck (Anchorage C-4 Quadrangle). In most areas, however, much of the upper Talkeelna Formation may have been removed by erosion.

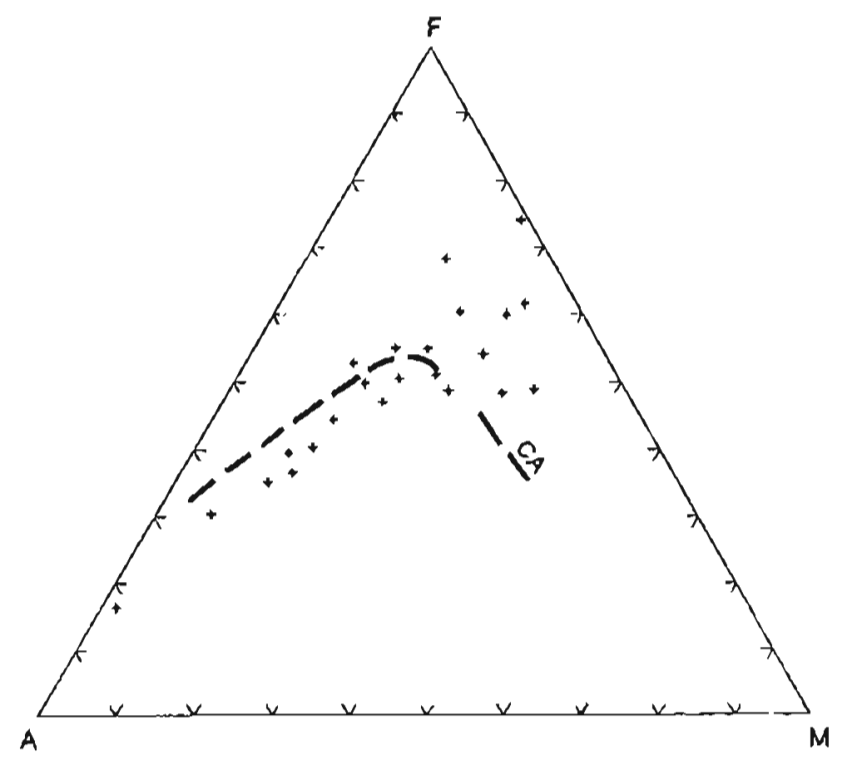

Figure 5. AFM diagram for Talkeelna Fonnation volcanic rocks. Calc-alkaline trend (denoted by $C A$ ) from Irvine and Baragar (1971). $A=100 x$ $\left(\mathrm{Na}_{2} \mathrm{O}+\mathrm{K}_{2} \mathrm{O}\right) /$ TOTAL, AFMi $\mathrm{F}=100 \times\left(0.9 \times \mathrm{Fe}_{2} \mathrm{O}_{3}\right.$ $+F e O) / T O T A L_{A F M ;} M=100 \times \mathrm{MgO} / T_{O} O$ TALAFM $_{A}$ where TOTAL ${ }_{A F M}=\mathrm{Na}_{2} \mathrm{O}+\mathrm{K}_{2} \mathrm{O}+0.9 \mathrm{~F}_{2} \mathrm{O}_{3}+$ $\mathrm{FeO}+\mathrm{MgO}$. Tick-marks indicale 10-percent intervals.
Most of the volcanic rocks bave been metamorphosed to the greenschist facies and are characterized by a variably altered phenocryst assemblage of plagioclasc, clinopyroxene, titanomagnelite, and either orthopyroxene or altered pigeonite. Primary amphiboles, alkali feldspar, and quartz are prescnt in the most felsic rocks. Malic minerals are generally aliered to chlorice, fibrous amphibole, and(or) clay. Plagioclase is altercd to clinozoisite(?), epidote, and albile. Titanomagnelitc is replaced by a fine-grained mixture of pyritc, sphene, and apatite. Zeolites are also common, especially in sedimentary members of the Talkcelna Formation (Hawkins, 1973).

Wholc-rock major-oxide analyses of 23 volcanic racks from the Talkeetna Formation in the northern Chugach Mountains and from Sheep Mountain rangc from basalt to rhyolite (table 1). Rocks within the andesite range are low- $\mathrm{K}$ as defined by Gill (1981) (fig. 4a). Large scatter in Harker diagrams may reflect the greenschist-facies metamorphism of the Talkeetna Formation (figs, 4a-g). Some of the scatter on the Harker diagrams could be produced by magma mixing or by crystal accumulation (insel, fig. 4b). No systematic compositional difference or trend is present in the rocks analyzed from any onc area.

The rocks appear to be largely calc-alkaline on an AFM diagram (fig. 5). However, on a plot of $\mathrm{FeO}^{*} / \mathrm{MgO}$ versus $\mathrm{SiO}_{2}$ (iig. 6), the Talkeetna Formation rocks showed two compositional irends,

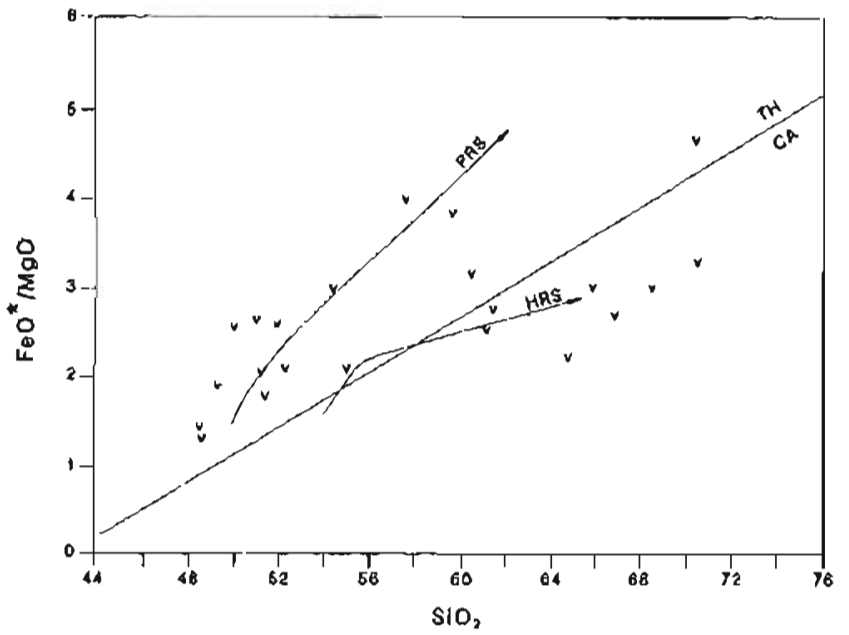

Figure 6. Variation diagram showing $\mathrm{SiO}_{2}$ plotted against $\mathrm{FeO}^{*} / \mathrm{MgO}$ for rocks from the Talkeema Fomation. Pigeonitic and hypersthentic rock series (PRS and HRS) from Gill (1981) who took them from Kuno (1968). Line for calc-alkaline (CA) and tholeiilic (TH) trends taken from Miyashiro (1974). 
similar to Kuno's (1968) average compositions of pigeonitic and hypersthenic rock series in Japan, and fell within both calc-alkaline and tholciitic ficlds of Miyashiro (1974). Thus, at least somc of the Talkeetna Formation rocks are probably tholeiitic in character. Barker and Graniz (1982) found that eight basalts and andesites of the Talkecina Formation from the Talkeetna Mountains have tholeittic characteristics and are medium-K by Gill's (1981) classification. In summary, based on the existing analyses, the Talkectna Formation south of the Matanuska Valkey is similar to the Talkectna Formation in the Talkeetra Mountains.

The age of the Talketna Formation on the Alaska Peninsula is constrained by lossiliferous Upper Triassic limestones stratigraphically bencath and by Bajocian (early Middle Jurassic) sandstones directly above the volcanic rocks. In the Talkectna Mountains, sparsely fossiliferous lower members and abundantly fossiliferous upper members indicate Sinemurian (Early Jurassic) to lace Bajocian ages (Detterman and Hartsock, 1966), or approximately 200 to $180 \mathrm{Ma}$ (Palmer, 1983). No K-Ar agc determinations have been attempted, due to the extensive alteration of the volcanic rock.

\section{PLUTONIC ROCKS}

Plutonic rocks of Jurassic age in the northern Chugach Mountains form both homogeneous and heterogeneous plutons. The homogeneous plutons occur in three major compositional types: (1) cumulate ultramafic rock, (2) gabbroic rocks, or (3) quartz diorite and tonalite. "Cumulate," used here as a textural term (as defined by Irvine, 1982), is not meant to imply magmatic processes resembling sedimentation.

The beterogeneous plutonic units contain mixtures of these three major types of plutonic rock, and are particularly abundant in the area mapped on sheet 1. The heterogeneous units were formed by repeated intrusion. A general sequence of multiple intrusions changing from mafic to more silicic types is seen all along the northern flank of the Chugach Mountains. The ultramafic rocks are intruded by, and are in part transitional to, gabbronorites ${ }^{8}$ (Newberry and others, 1986), which, in turn, are intruded by dikes and large plutons of quartz diorite, tonalite, and minor granodioritc. The gabbroic rocks appear to have crystallized both in relatively large magma chambers and as multiple dikes of varying

8plutonic rock names used in this report are consistent wilh Streckeisen (1976). sizes (Burns, 1985, in press). The quartz diorite and conalite intruded the gabbroic rocks and appear to have crystalized structurally above the gabbroic rocks as relatively homogeneous masses. Dikes of quartz diorite and tonalite in the gabbroic rocks are particularly abundant where the gabbroic rocks crystallized as dikes. Ductile deformation textures of contacts between gabbroic and quartz dioritic rocks suggest that the gabbroic rocks were not completely crystallized when the quartz dioritic magma intruded (Burns, 1983, in press).

Major exposures of gabbroic and ultramafic rocks along the Border Ranges faule system in the northern Chugach Mountains include the Tonsina maficultramafic assemblage; Nelchina River Gabbronorite (formally named in Burns, in press); the Wolverine, Eklutra, and Kodiak complexes; and the Klanelneechena and Red Mountain klippen. These rocks are collectively referred to as the Border Ranges udtramafic and mafic complex (BRUMC) (Burns, 1985). The Wolverine complex and the Nelchina River Gabbronorite, plus numerous urnamed fault slices of gabbroic rocks, crop out in the Nelchina-Kings Mountain area. These mafic and ultramafic rocks are exposed as elongate structural blocks tens to hundreds of kilometers long.

\section{Cumulate Ultramafic Rocks}

The Wolverine complex consists dominantly of ultramafic rocks and crops out in the Anchorage C-4 and C-5 Quadrangles (figs. 2, 3) (Clark, 1972b, 1983; Pavlis, 1982a, 1983; Little and others, 1986b). Minor amounts of ultramafic rocks, including cumulatc dunite, clinopyroxenite, troctolite, and lesser barzburgite, are also present in the southern part of the Nelchina River Gabbronorite in the Anchorage C-2 Quadrangle (fig. 3). The ultramafic rocks in the Nelchina River Gabbronorite are not differentiated on the map and are not discussed in this paper.

Petrology and Lithology.-The Wolverine complex is composed of fault-bounded blocks of ultramafic rocks (dunice - Jd; clinopyroxenite and websterite - Jow, harzburgite and peridotite - Jp; sheet 1 ) and mafic rock (gabbronorite and homblende gabbro - Jgu; sheet 1). Much of the layering and diking is 100 complex to be shown at map scale; thus, a unit of uframafic undifferentiated (Juu) and a unit of mafic-ultramafic undifferentiated (Jmu) are also shown on sheet 1. Fault-bounded blocks of amphibolite, metachert, and talc schist (Mza, Mzsh, and Mzm) are spatially associaled with the ultramafic rocks (Pavlis, 1983; Newberry, 1986). 
The fault blocks which make up the Wolverine complex are 60 to $600 \mathrm{~m}$ wide and trend norlheastsouthwest. Ultramafic rocks predominate in the southeastern portion of the complex; gabbroic rocks are more abundant to the northwest (Clark, 1972b; Pavlis, 1983; Little and others, 1986b). Layering generally dips to the south. The ultramafic rocks cxhibit gradational and faulted contacts with gabbronorites to the north (Newberry, 1986).

The bulk of the Wolverine complex is composed of ultramafic cumulates interlayered with and intruded by mafic rocks. Dunite, chromite-bearing dunite, wchslite, olivine clinopyroxenite, clinopyroxenite, gabbronorite, and hornblende gabbro arc the main rock types present. Small amounts of cumulate websterite and tectonized harzburgite occur in the Wolverine body, and the haraburgite may represent residual mantle; howcver, no sludics on rock fabrics have been done to separatc deformation by Cretaceous faulting from that occurring in the mantle.

Dunite is commonly massive, but thin layers or bands (1 $\mathrm{cm}$ to $1 \mathrm{~m}$ thick) of clinopyroxenite and (or) wehrlite in dunite are also common. The layering commonly dips to the southeast but is disrupted by faulting. Where abundant, chromite gencrally occurs in the dunite as deformed, wispy layers meters to tens of meters long (possibly to $100 \mathrm{~m}$ ) (Newberry, 1986). Dikes of gabbronorite and hornblende gabbro 5 to $40 \mathrm{~m}$ thick are present within the clinopyroxenites and dunites.

Mineralogy.-Dunites are composed predominantly of fine- to coarse-grained (commonly 3 to $5 \mathrm{~mm}$ diam) olivine. Disseminated chromite (about 2 percent) is common. Chromite forms rounded crystals, suggesting interaction with liquid and(or) olivine crystals. Clinopyroxene \pm orthopyroxene crystals are present in some dunites as cumulus phases; however, most clinopyroxene crystals form an intercumulate phase. Dunites are typically serpentinized, obscuring textural relations. Many chromite grains are surrounded by a halo of magnetite dust formed during serpentinization.

Clinopyroxenites and olivine clinopyroxenites of the Wolverine Complex are composed dominantly of coarse ( 3 to $7 \mathrm{~mm}$ ) cumulate crystals of clinopyroxene. Olivine, orthopyroxene, and a brownto-greenish spinel (pleonaste) are present in varying amounts. The clinopyroxene grains commonly contain growth twins, and less commonly, narrow exsolution lamellae of orthopyroxene. Websterite generally contains more clinopyroxene than orthopyroxene. Textures are generally adcumulate, with both pyroxenes prescnt as cumulus phases.

Alteration and Metamorphism.-The Wolverine rocks arc the most highly altered ultramafic rocks in the BRUMC; they are the only ultramafic rocks in the complex known to commonly contain abundant secondary cummingtonite. Scrpentinization, which occurs at a lower temperature than that required for formation of cummingtonite, is also extensive. Alteration of rocks in the Wolverine area is intense, probably because of numerous faults which would have provided access for fluids. Tonalitc-trondhjemite plutons of Cretaceous age may have provided fluids and heat for this alteration.

Deformation.-The deformational history of the cumulate rocks in the Wolverine body is complex and, as yet, poorly understond. Olivine commonly shows kink banding, and in many rocks, both types of pyroxenes show undulatory extinction. A small amount of recrystallized olivine with marked grainsize reduction is present in many rocks, and is indicative of dynamic recrystallization under relatively high stress (Giradeau and Nicolas, 1981). Clinopyroxene and hornblende crystals are commonly recrystallized. These deformational features probably developed when the rocks were still hot; that is, the rocks are metacumulates as in otber ophiolitic-type complexes: for cxample, Bay of Islands (Christensen and Salisbury, 1979); Troodos (George, 1978); and Canyon Mountain (Avé Lallemant, 1976).

Some deformation features of the Wolverine complex, however, are related to younger, morc brittle deformation of probable Late Crclaceousearly Terijary age. Broken and breccialcd clinopyroxene and hornblende, and possibly strain lamellae in clinopyroxene, are examples of the younger deformation. Brittle deformation probably occurred in two stages: the first associated with thrusting of the Peninsular terrane over the McHugh Complex, and the second associated with the Tertiary bigh-angle fault system (see Siructural Gcology section). Some ductile deformation and recrystallization described above may have occurred during early thrusting.

\section{Gabbroic Rocks}

Gabbroic rocks are the most abundant plutonic rocks in the northern Chugach Mountains. The western part of the Nelchina River Gabbronorite, a 
body composed dominantly of gabbroic rocks, crops out in the map area in the Anchorage C-1 and C-2 Quadrangles, Gabbroic rocks crop out also in fault conlact at the base of the quartz diorite pluton in the Anchorage C-3 Quadrangle, as xenoliths in other quartz diorite and tonalite plutons, and in association with large masses of ultramafic rock in the Anchorage C.5 Quadrangle (the Wolverine complex; figs, 2, 3).

Petrology and Lithology.-The undifferentiated gabbroic rock unit (Jgu) consists dominantly of gabbronorite (or two-pyroxcne gabbro), magnetitc gabbronorile, and anorthositic gabbronorite; norites, anorthosites, pyroxenc-hornblende gabbronorites, and lesser hornblende gabbros and ultramafic rocks are also present. A garnet clinopyroxcnite (most likely a reequilibrated gabbronorite [Burns, 1985]) was found within this gabbroic unit in a faultbounded slice near the Nelchina Glacicr (fig. 3). Other map units that contain gabbroic rocks form complex intrusive mixtures composed of gabbroic rocks and either ultramafic rocks (Jmu), dioritic rocks (Jdgu), quartz diorites (Igqd), or migmatisic textured metasedimcntary and metavolcanic rocks (Mzmp). These rock lypes also occur in very minor amounts within the main gabbroic rock unit. Dikcs and small veins of trondhjemite of Late JurassicEarly Cretaceous age and felsite dikes of Tertiary age are common in the zones of cataclastically deformcd gabbroic rocks.

Some of the gabbroic rocks are massive with little or no directional fabric. Other gabbroic rocks consist of layers and dikes. Layers range from $1 \mathrm{~cm}$ $105 \mathrm{~m}$ thick. Thin layers pinch out and commonly have strike lengths of $<20 \mathrm{~m}$. Most of the layering is defined by modal variation in pyroxene and plagioclase content. Narrow (1 $\mathrm{cm}$ wide) layers of anorthosite are commonly interlayered with the gabbronorites. Minor pegmatitic pods (to $15 \mathrm{~cm}$ long) of homblende and plagioclase are present in some of the layered gabbronorites and some locally hornblende-plagioclase veins cut across the layering of the gabbroic rocks. The layering may be caused by a combination of flow segregation, periodic crystallization, and new pulses of magmatic injection. Most layered rocks display igneous lamination, an alignment of " $c$ " axis of plagioclase and pyroxene grains, which probably resulted from moderate pressure during cooling.

Layering, clearly produced by multiple intrusion, is present in the Nelchina transect (Burns, 1983, in press), in the southern part of the Anchorage C-2 Quadrangle (fig. 3), and in most of the gabbroic units in the Anchorage C-4 and C-5 Quadrangles. The areas of multiple intrusion, referred to herein as dike complexes, commonly include quartz diorite and tonalite dikes, as well as many generations of gabbroic dikes. Stretched and boudinaged dikes and migmatitic-textured contacts between quartz diorite and gabbronorite indicate that the gabbroic rocks werc still bot and ductile during intrusion of the quartz diorites (Burns, 1983, in press).

Mineralogy.-On the basis of mineralogy, Burns (1983) classified the gabbroic rocks into two main categories: (1) the gabbronorite clan, and (2) pyroxene-hornblende gabbronorite and hornblende gabbro. Rocks of the gabbronorite clan form the majority of the undifferentiated gabbroic rock unit (Jgu) and contain very minor amounts of hornblende, whereas rocks in the second category contain $>10$ modal percent coarse-grained magmatic or early deuteric hornblende. The pyroxenehornblende gabbronorite and hornblende gabbro form a large component of the diorite-gabbro unit (Jdgu) as well as occurring in the undifferentiated gabbroic rock unit (Jgu) and as a minor component in the diorite-quartz diorite unit (Jdqd). Major-oxide analyses and CIPW norms of sample from both these groups (table 2) showed the pyroxenc hornblende gabbronorites to be slightly more differentiated than rocks of the gabbronorite clan. No other compositional differences were apparent. More detailcd petrograpbic descriptions of the gabbroic rocks and mineral compositions than are given below are presented by Burns (1983, 1985, in press).

Gabbronorite clan.-Most of the gabbroic rocks in the Nelchina-Kings Mountain region are rocks of the gabbronorite clan and include gabbronorite, leucogabbronorite, anorthosite, magnetite gabbronorite, and leuconorite. Fine- to mediumgrained gabbronorites form 45 to 55 percent of the exposed gabbroic rocks. Gabbronorites weather reddish brown but are whitish gray where extensively fractured and altered to zeolites. Gabbronorites contain 15 to 30 percent orthopyroxene, 15 to 30 percent clinopyroxene, 40 to 65 percent plagioclase (Ang5-75), 0 to 10 percent (commonly $<5$ percent) pargasitic hornblende, and to 10 percent magnetite and ilmenite (commonly 2 to 6 percent). Trace amounts of apatite are present in a few rocks. Iron-rich green spinel (pleonaste) is present in the more magnesium- and calcium-rich gabbronoritcs.

Leucogabbronorite and lesser anorthosite form 20 to 30 percent of the exposed gabbroic rocks. A smals amount of leuconorite is also present. 
Leucogabbronorite and leuconorite contain 65 to 90 percent plagioclase (Angs-70) and 10 to 35 percent pyroxenes. Hornblende, magnetite and itmenite geverally form $<3$ percent. The leucocratic rocks are commonly medium grained, but layers with extremely coarse-grained $(1.5 \mathrm{~cm})$ plagioclase crystals are also typical. Many of the leucocratic rocks weather white, but where plagioclase grains are calcic ( $A_{80-95}$ ) and unaltered, the rock retains a clear, greenish sheen in outcrop.

Pyroxene-homblende gabbronorite-Pyroxene. hornblende gabbronorite is most common in dike complexes, and composes about 10 to 15 percent of thc exposed gabbroic rocks in the Nelchina-Kings Mountain region. They crop out directly west of the Nelchina Glacier in the Anchorage C-1 Quadrangle, in the southern part of the Anchorage C-2 Quadrangle, and in scattered places in the Anchorage C-4 and $\mathrm{C}-5$ Quadrangles. These rocks commonly are fine grained and weather black. Minor amounts of horablende gabbro and diorite(?) are commonly associated with the pyroxene-hornblende gabbronoritc, particularly in the Anchorage C-4 and C-5 Quadrangles.

The unit typicalty is composed of fine-graincd gabbronorite and magnetite gabbronorite that contain coarse-grained hornblende, magoetite, ilmenite, and plagioclase in veins 1 to $2 \mathrm{~cm}$ wide and in discontinuous, elongated pods. The resuling rock is composed of 15 to 30 percent hormblende, 40 to 60 percent plagioclase, 10 to 30 percent pyroxenes, and commonly as much as 8 to 15 percent magnetite and ilmenite. Hornblende is tan in thin section. Apatite is much more common in the pyroxeachornblende gabbronorites than in the gabbronorites, but still composes $<2$ modal percent.

On the basis of mineral growth, field relationships, and petrographic textures, these rocks are interpreted to form at high temperatures by circulation of vapor phases through gabbronorites and magnetite gabbronorites (Burns, 1983, in press). The vapor phase caused coarse-grained hornblende, magnetite, ilmenite, and plagioclase to crystallize. In places, the younger mineralogy obscurcs the older.

\footnotetext{
Alteration and Metamorphism.-Many alteration assemblages caused both by deuteric and metamorphic processes are present in the gabbroic rocks. Three major deuteric assemblages can be identified on the basis of mineralogy and mineral compositions. Several localized metamorphic events, including intrusion of quartz diorite-tonalite, intrusion of felsite plugs, and low temperature
}

alteration adjacent to fault zones, are also recorded in the gabbroic rocks.

Deuteric assemblages are discussed here in terms of decreasing temperatures and progressive alteration. The least altered gabbroic rocks contain orthopyroxene (dominantly low-calcium hypersthene), diopside-salite, and calcic plagioclase \pm magnetite and lesser ilmenite \pm minor pargasitic hornblende. Temperature estimates based on the two-pyroxene geothermometer of Ross and Huebner (1975) for host pyroxene compositions of the gabbroic rocks suggest that exsolution lamellac in pyroxene crystals probably formed as the rocks cooled to about 800 to $950{ }^{\circ} \mathrm{C}$ (Burns, 1985). The pargasitic hornblende probably formed only during reequilibration and does not appear to be a primary magmatic phase. These mineral asscmblages and compositions are characteristic of rocks which recquilibrated in granulite facies conditions.

As temperatures decreased, cummingconitc/anthophyllite \pm magnetite \pm minor quartz formed pscudomorphs after orthopyroxene. The main minerals present in this second assemblage (diopside, cummingtonite/anthophyllite, and calcic plagioclase \pm mioor pargasitic hornblende) are similar to minerals formed in temperatures of upper amphibolite metamorphism (labradorite/bytownite amphibolite facies of Winkler, 1974).

Lower amphibolite facies and greenschist facies are represented by growth of clinozoisite in plagioclase and partial to complete replacement of orthopyroxene crystals (or its alteration products) with chlorite \pm sphene. Clinopyroxenc and homblende remain unaltered in the gabbroic rocks except in areas of Tertiary faulting, near other intrusions, and in areas affected by hydrothermal circulation.

Intense hydrothermal alteration has occurred in large areas of the gabbroic rocks at greenschist facies conditions. These gabbroic rocks are commonly present in dike complexes, and many had been previously altered by vapor phases to the magnetite pyroxene-hornblende gabbronorite discussed above. Hydrothermal alteration produced pervasive chloritization, chlorite veining, and abundant quartzepidote veins. Ortho- and clinopyroxene (or their alteration products) altered to chlorite ( \pm epidote), magnetite altered to chlorite, and clinozoisite altcred to epidote. Minor veining of hornblende by chlorite is also common, and calcite, albite, quartz, sphene, pyrite, and chalcopyrite arc present in minor amounts. Actinolite, generally considered to bc a characteristic mineral of mafic rocks in the greenschist facies, is rarcly present. 
Table 1. Major-oxide analyses and CIPW noms on volcanic rocks of the Talkeetna Fomation $\mathrm{M}, \mathrm{MgO} /\left(\mathrm{Na}_{2} \mathrm{O}+\mathrm{K}_{2} \mathrm{O}+\mathrm{FeO}^{*}+\mathrm{MgO}\right) ;-$, not anplicable; nom An, an/(an+ab+or); $\mathrm{Ab}$, ab/(an+ab+or); Or. or/(an+ab +or); SM. Sheep Mountain]

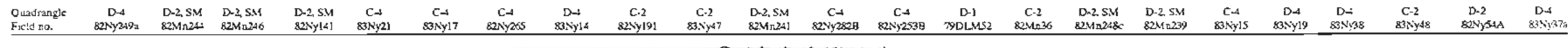

\begin{tabular}{|c|c|c|c|c|c|c|c|c|c|c|c|c|c|c|c|c|c|c|c|c|c|c|c|}
\hline 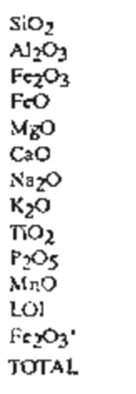 & 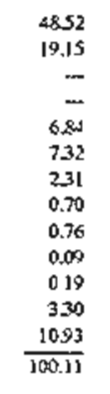 & 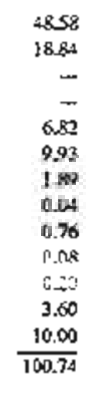 & 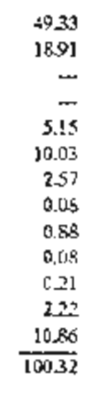 & 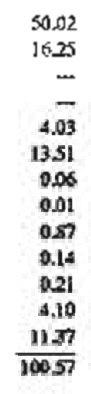 & 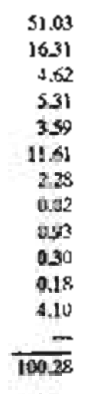 & 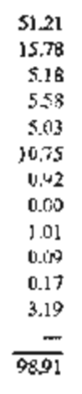 & 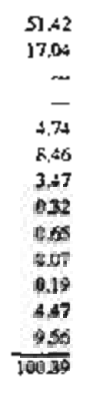 & 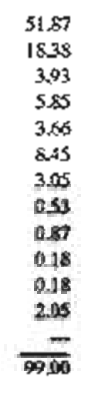 & 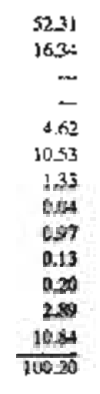 & 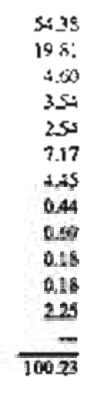 & 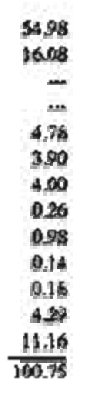 & 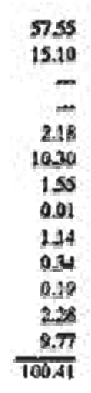 & 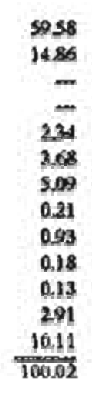 & 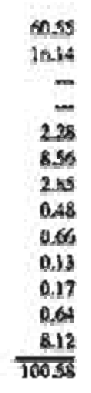 & 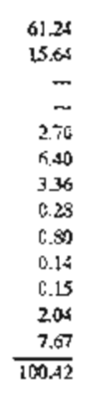 & 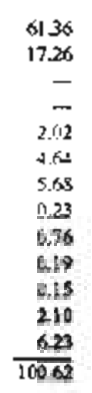 & 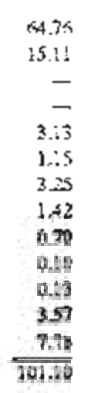 & 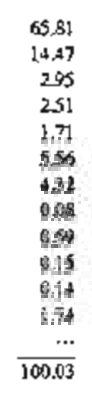 & 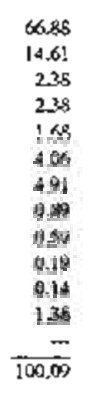 & 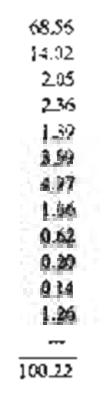 & 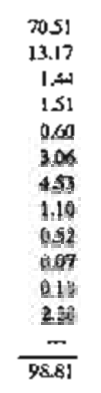 & 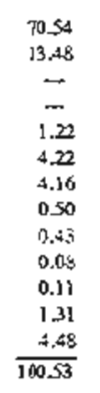 & 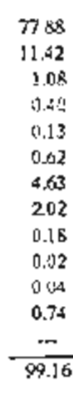 \\
\hline $\begin{array}{l}\mathrm{FeCO} \\
\mathrm{FeO} \% \mathrm{MgO}^{\circ}\end{array}$ & $\frac{9.82}{1.4}$ & $\begin{array}{l}8.98 \\
1.3\end{array}$ & $\begin{array}{l}9.75 \\
19\end{array}$ & $\begin{array}{c}10.23 \\
25\end{array}$ & 量然 & $\begin{array}{r}1023 \\
2.0\end{array}$ & 888 & $\begin{array}{l}9.38 \\
26\end{array}$ & $\begin{array}{l}9.73 \\
2.1\end{array}$ & $\begin{array}{l}2.07 \\
30.0\end{array}$ & $\begin{array}{c}10,22 \\
21\end{array}$ & $\begin{array}{l}8.7 \\
4.0\end{array}$ & $\begin{array}{l}9.98 \\
39\end{array}$ & $\begin{aligned} 720 \\
32\end{aligned}$ & $\frac{6.80}{26}$ & $\begin{array}{l}5989 \\
28\end{array}$ & $\begin{array}{l}690 \\
22\end{array}$ & $\begin{array}{c}5.65 \\
3.0\end{array}$ & $\begin{array}{l}+52 \\
27\end{array}$ & $\begin{array}{l}\frac{4.20}{3.0} \\
3\end{array}$ & $\begin{array}{l}2800 \\
4.7\end{array}$ & $\begin{array}{l}5.02 \\
3.3\end{array}$ & $\begin{array}{l}1,30 \\
105\end{array}$ \\
\hline F & 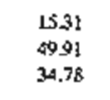 & 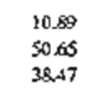 & 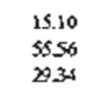 & $\begin{array}{l}0.09 \\
735 \\
23.16\end{array}$ & 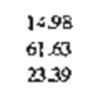 & 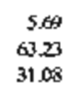 & $\begin{array}{l}231.4 \\
5.10 \\
27.70\end{array}$ & $\begin{array}{l}2115 \mathrm{~s} \\
\text { stas } \\
2002\end{array}$ & $\begin{array}{r}8,7 \\
6091 \\
20.998\end{array}$ & $\begin{array}{l}32225 \\
50.505 \\
16.52\end{array}$ & $\begin{array}{l}2225 \\
25255 \\
25.08\end{array}$ & $\begin{array}{l}1247 \\
7017 \\
17,22\end{array}$ & 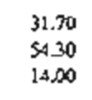 & $\begin{array}{l}5.61 \\
565.2 \\
17.67\end{array}$ & $\begin{array}{l}n 552 \\
52207 \\
30.61\end{array}$ & 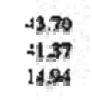 & $\begin{aligned} 31.58 \\
4.728 \\
2.11\end{aligned}$ & $\begin{array}{l}39.14 \\
45.78 \\
15: 17\end{array}$ & $\begin{array}{l}2535 \\
73725 \\
25.00\end{array}$ & 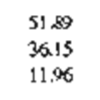 & $\begin{array}{l}\frac{62.38}{30.109} \\
6.654\end{array}$ & $\begin{array}{l}47.06 \\
4.062 \\
12.232\end{array}$ & $\begin{array}{c}81.60 \\
16.81 \\
1.50\end{array}$ \\
\hline
\end{tabular}

\begin{tabular}{|c|c|c|c|c|c|c|c|c|c|c|c|c|c|c|c|c|c|c|c|c|c|c|c|}
\hline 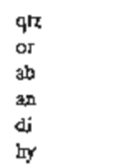 & $\begin{array}{l}1.6 .5 \\
30.4 \\
37.2 \\
27.8\end{array}$ & $\begin{array}{l}3.0 \\
0.2 \\
10.5 \\
4.4 . \\
5.0 \\
50.6\end{array}$ & $\begin{array}{l}23.5 \\
0.5 \\
22.4 \\
4.0 \\
80 \\
80.6\end{array}$ & 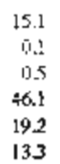 & $\begin{array}{l}112.2 \\
0.1 \\
201 \\
35.6 \\
151 \\
51 \\
51\end{array}$ & $\begin{array}{l}172 \\
\frac{81}{801} \\
411.6 \\
12.8\end{array}$ & $\begin{array}{c}32.2 \\
320 \\
310.5 \\
10.0 \\
12.0\end{array}$ & $\begin{array}{c}7.5 \\
3.2 \\
366 \\
3.0 \\
19.6 \\
1.30\end{array}$ & 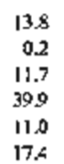 & $\begin{array}{c}78 \\
27 \\
38.4 \\
355 \\
313 \\
7.8\end{array}$ & 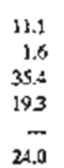 & $\begin{array}{l}24.3 \\
0.1 \\
1: 5 \\
35.1 \\
32.1 \\
12.6\end{array}$ & 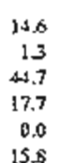 & 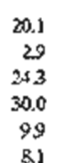 & $\begin{array}{l}21.9 \\
1.9 \\
x .1 \\
27.4 \\
3 ., 4\end{array}$ & $\begin{array}{l}13.8 \\
1.8 \\
1.90 \\
21.3 \\
0.7 \\
0.7\end{array}$ & $\begin{array}{l}316 \\
87 \\
28.6 \\
522 \\
-7\end{array}$ & $\begin{array}{l}276 \\
05 \\
372 \\
3722 \\
5,5\end{array}$ & $\begin{array}{r}2.6 .6 \\
5.3 \\
421 \\
15.4 \\
30 \\
3.4\end{array}$ & $\begin{array}{c}26.6 \\
63 \\
425 \\
193 \\
39.9 \\
39\end{array}$ & $\begin{array}{c}339 \\
697 \\
397 \\
128 \\
20\end{array}$ & $\begin{array}{c}3.0 \\
3.0 \\
35.6 \\
1.6 .8 \\
3.1\end{array}$ & $\begin{array}{c}42.8 \\
121 \\
39.8 \\
3.0 \\
-. .\end{array}$ \\
\hline 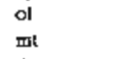 & $\frac{10}{34}$ & 3 & $\cdots$ & $\overline{3.6}$ & 7.0 & $\because$ & 3 & 5 & 3. & $\overline{6}$ & 38 & -7 & $\overline{37}$ & $\frac{1}{37}$ & -2 & $=$ & $\therefore$ & - & $=$ & $\stackrel{39}{-}$ & $=$ & - & 13 \\
\hline $\begin{array}{l}\Delta \\
\text { uxp }\end{array}$ & 15 & is & 1.7 & $\begin{array}{l}1.7 \\
0.3\end{array}$ & $\begin{array}{l}1.8 \\
\mathbf{0} 8\end{array}$ & $\begin{array}{l}20 \\
0.2\end{array}$ & 13 & $\begin{array}{l}1.7 \\
0.4\end{array}$ & 19 & 13 & 19 & 2.22 & 18 & 13 & 1.6 & is & 1.4 & 1.1. & 1.1 & 12 & 1.0 & 0.8 & 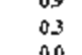 \\
\hline 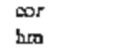 & $\stackrel{1.6}{-2}$ & z & $=$ & $=$ & $=$ & $=$ & $=$ & $=$ & $=$ & $\bar{z}$ & 26 & $\bar{z}$ & $=$ & $=$ & $=$ & $=$ & 6.5 & $\bar{z}$ & $=$ & $=$ & 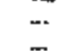 & $=$ & $\begin{array}{l}0.5 \\
0 \leq 5\end{array}$ \\
\hline & $\begin{array}{l}\infty .1 \\
* 0.1\end{array}$ & 725 & $\begin{array}{l}4.2 \\
x \leq 1\end{array}$ & 987 & 038 & 83 & $\$ 0$ & $\$, 7$ & mo & $\$ 3$ & $\begin{array}{r}343 \\
400\end{array}$ & $\begin{array}{l}722 \\
772\end{array}$ & 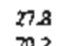 & 525 & 57.1 & $x$ & 123 & 34.9 & 24,5 & 21.0 & 21.5 & 30.4 & 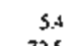 \\
\hline $\begin{array}{l}\mathrm{Ab} \\
\mathrm{D} r\end{array}$ & $\begin{array}{c}328 \\
7.0\end{array}$ & $\begin{array}{l}27.1 \\
0.4\end{array}$ & $\begin{array}{l}35.0 \\
0.5\end{array}$ & .1. & $\begin{array}{l}36.0 \\
022\end{array}$ & $\begin{array}{l}167 \\
1\end{array}$ & 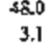 & $\begin{array}{l}\text { s.t.4 } \\
1,9\end{array}$ & $\begin{array}{l}225 \\
05\end{array}$ & $\begin{array}{l}\frac{51.6}{3.6} \\
3\end{array}$ & $\begin{array}{r}629 \\
28\end{array}$ & $\begin{array}{c}77.7 \\
0.1\end{array}$ & $\begin{array}{l}0.2 \\
20\end{array}$ & $\begin{array}{l}255 \\
50\end{array}$ & $\begin{array}{c}50.0 \\
29\end{array}$ & $\begin{array}{l}6.33 \\
1.9\end{array}$ & $\begin{array}{l}572.2 \\
205\end{array}$ & $\begin{array}{c}4,3 \\
0.8\end{array}$ & $\begin{array}{l}67.0 \\
8 \leq 5\end{array}$ & $\begin{array}{ll}6.8 \\
0.02\end{array}$ & $\begin{array}{l}67.8 \\
11,\end{array}$ & 64.3 & 725 \\
\hline
\end{tabular}


Table 2. Major-oxide analyses and CIPW noms on gabbroic rocks from the nonthcentral Chugach Moumtains

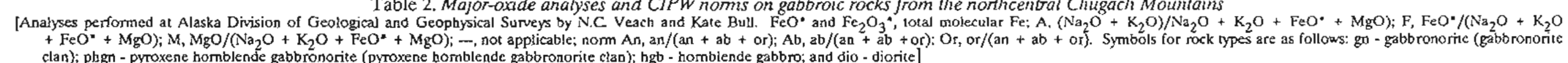

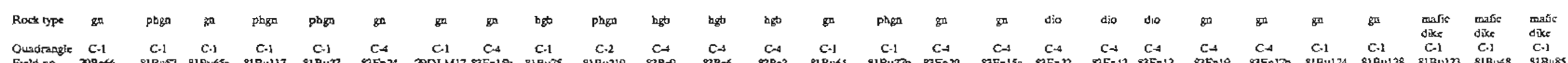

\begin{tabular}{|c|c|c|c|c|c|c|c|c|c|c|c|c|c|c|c|c|c|c|c|c|c|c|c|c|c|c|c|}
\hline 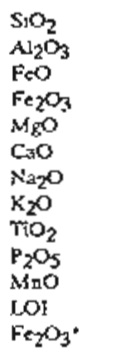 & 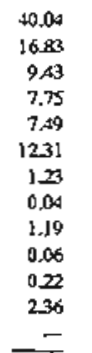 & 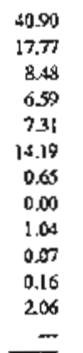 & 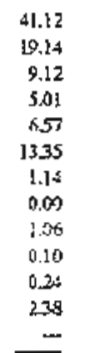 & 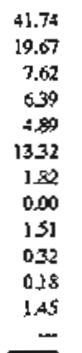 & 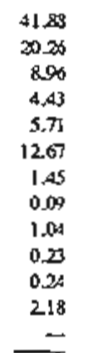 & 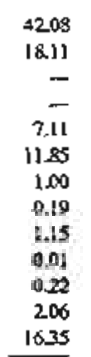 & 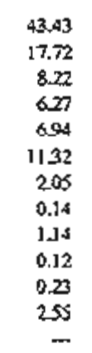 & 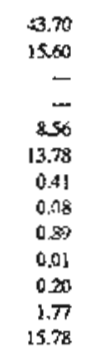 & 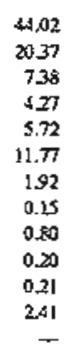 & 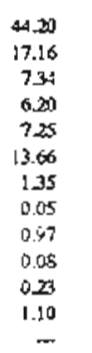 & 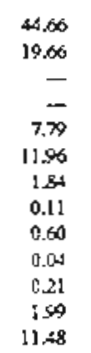 & 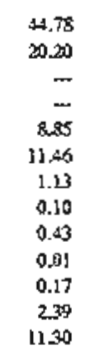 & 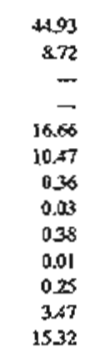 & 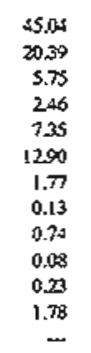 & 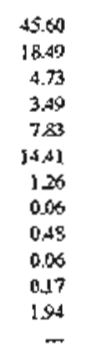 & 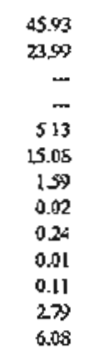 & 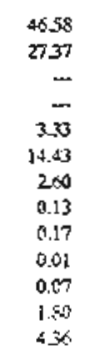 & 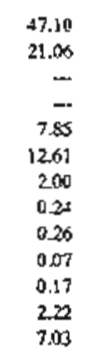 & 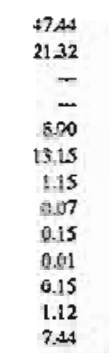 & 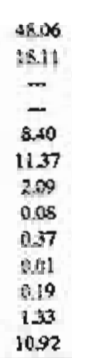 & 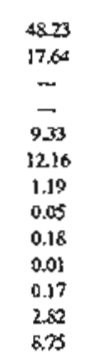 & 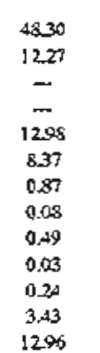 & 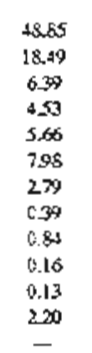 & 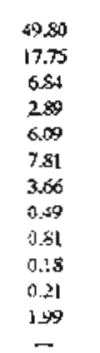 & 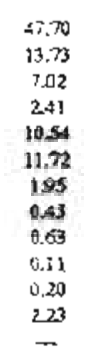 & 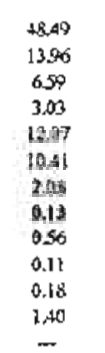 & 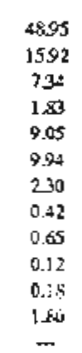 \\
\hline TOTAL & $\overline{98055}$ & $\overline{\bar{M} 2 \overline{2}}$ & $\overline{\overline{9} .23}$ & $\overline{989,9}$ & $\overline{9.18}$ & $\frac{100.13}{100}$ & $\overline{100.13}$ & $\frac{10.08}{100.88}$ & $\overline{p_{22}}$ & $\overline{999}$ & $\frac{1508}{10034}$ & $\frac{10088}{100.8}$ & $\frac{100.60}{100.60}$ & $\overline{98.62}$ & $\overline{9852}$ & $\frac{100987}{1009}$ & $\overline{100.25}$ & $\frac{10066}{100.6}$ & $\frac{10000}{10000}$ & $\frac{100093}{10093}$ & $\frac{1100.5}{100}$ & 100,02 & $\overline{8 \$+1}$ & $\overline{9852}$ & $\overline{9_{Q, 67}}$ & $\overline{9 ; 01}$ & $\overline{9850}$ \\
\hline 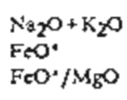 & $\begin{array}{l}1.27 \\
16,40 \\
2.19\end{array}$ & $\begin{array}{c}0.05 \\
1,41 \\
1.97\end{array}$ & $\begin{array}{l}1.14 \\
13 \times 3 \\
207\end{array}$ & $\begin{array}{c}182 \\
137 \\
273\end{array}$ & $\begin{array}{l}154 \\
1205 \\
2.27\end{array}$ & 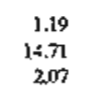 & $\begin{array}{r}219 \\
13,36 \\
200\end{array}$ & $\begin{array}{c}0.99 \\
1.20 \\
1.60\end{array}$ & $\begin{array}{l}207 \\
1322 \\
1.28\end{array}$ & $\begin{array}{r}1.4 \\
12.42 \\
1.78\end{array}$ & $\begin{array}{c}195 \\
19.33 \\
1.33 \\
133\end{array}$ & $\begin{array}{l}1.28 \\
10.17 \\
1.15\end{array}$ & 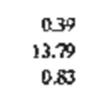 & $\begin{array}{r}1.9 \\
796 \\
1.08\end{array}$ & $\begin{array}{c}132 \\
7.87 \\
101\end{array}$ & $\begin{array}{l}1.61 \\
s: 97 \\
1.07\end{array}$ & $\begin{array}{l}273 \\
3.92 \\
.1 .18\end{array}$ & $\begin{array}{l}2.24 \\
6.83 \\
0.81\end{array}$ & $\begin{array}{l}1.22 \\
6.0 \\
0.03\end{array}$ & $\begin{array}{l}217 \\
9,83 \\
1.17\end{array}$ & $\begin{array}{l}1,24 \\
7,87 \\
0.24\end{array}$ & $\begin{array}{c}0.95 \\
\substack{11060 \\
0,900}\end{array}$ & $\begin{array}{c}3.18 \\
10,47 \\
1.58\end{array}$ & $\begin{array}{l}.1 .15 \\
\text { s.14 } \\
15 s\end{array}$ & $\begin{array}{l}2.38 \\
9.19 \\
0.87\end{array}$ & $\begin{array}{l}221 \\
9321 \\
0.77\end{array}$ & $\begin{array}{l}2 \pi x \\
s, 0 \\
0.09\end{array}$ \\
\hline 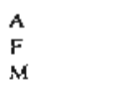 & $\begin{array}{c}5.0 \\
6052 \\
29.8\end{array}$ & $\begin{array}{c}29 \\
61.4 \\
327\end{array}$ & $\begin{array}{c}53 \\
639 \\
398\end{array}$ & 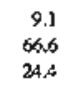 & $\begin{array}{c}7.6 \\
6.1 \\
2883\end{array}$ & $\begin{array}{c}52 \\
639 \\
30.9 \\
30.9\end{array}$ & $\begin{array}{l}95 \\
603 \\
302\end{array}$ & $\begin{array}{c}2.1 \\
60.19 \\
3 x, 9\end{array}$ & $\begin{array}{l}105 \\
000 \\
2890\end{array}$ & $\begin{array}{l}105 \\
605 \\
289\end{array}$ & $\begin{array}{r}9.7 \\
S 1.4 \\
389\end{array}$ & $\begin{array}{c}6.1 \\
502 \\
13.8\end{array}$ & $\begin{array}{c}1.3 \\
4.4 .7 \\
3 \rightarrow 1.1\end{array}$ & $\begin{array}{l}105 \\
605 \\
289 \\
289\end{array}$ & $\begin{array}{l}205 \\
605 \\
289\end{array}$ & $\begin{array}{l}132 \\
435 \\
420\end{array}$ & $\begin{array}{l}\frac{7.4}{32.4} \\
32.2 \\
32.4\end{array}$ & $\begin{array}{l}13.7 \\
378 \\
379\end{array}$ & $\begin{array}{r}7.3 \\
39.8 \\
3.0\end{array}$ & $\begin{array}{l}10.5 \\
4 \leqslant 1 \\
\leqslant 1.2\end{array}$ & 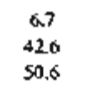 & $\begin{array}{l}3.7 \\
45.5 \\
30.8\end{array}$ & $\begin{array}{l}16 s \\
452 \\
83\end{array}$ & $\begin{array}{l}21.1 \\
\text { sis. } \\
31.0\end{array}$ & $\begin{array}{l}10.8 \\
4.15 \\
47.7\end{array}$ & $\begin{array}{l}9.4 \\
3095 \\
51.2\end{array}$ & $\begin{array}{l}13.1 \\
3.13 \\
4.3 .6\end{array}$ \\
\hline
\end{tabular}

\begin{tabular}{|c|c|c|c|c|c|c|c|c|c|c|c|c|c|c|c|c|c|c|c|c|c|c|c|c|c|c|}
\hline & & $\begin{array}{c}- \\
5.7 \\
5.9 \\
469 \\
203 \\
79 \\
7.2 \\
9.5 \\
20 \\
0.2\end{array}$ & 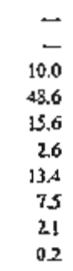 & $\begin{array}{l}= \\
5.8 \\
15.7 \\
45.5 \\
1.4 \\
75 \\
95 \\
29 \\
0.8\end{array}$ & $\begin{array}{l}10.5 \\
127 \\
50.0 \\
10.9 \\
12.3 \\
12.6 \\
6.6 \\
20.5 \\
0.5\end{array}$ & 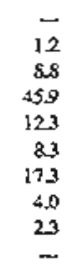 & 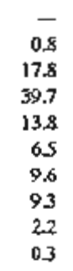 & $\begin{array}{l}0.5 \\
3.6 \\
1.5 \\
175 \\
11.6 \\
14.6 \\
3.5 \\
1.7 \\
7\end{array}$ & 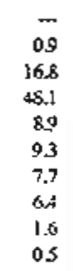 & 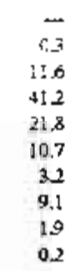 & $\begin{array}{l}0.7 \\
10.0 \\
16.3 \\
11.18 \\
28 \\
18.2 \\
3.1 \\
1.2 \\
0.1\end{array}$ & 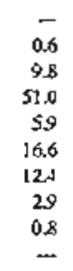 & 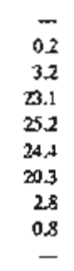 & 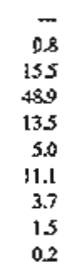 & $\begin{array}{c}0 . \\
0.4 \\
1100 \\
152 \\
259 \\
155 \\
217 \\
52 \\
09 \\
0.1\end{array}$ & 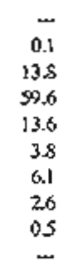 & 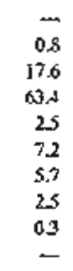 & 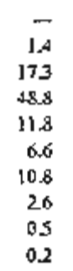 & 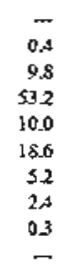 & $\begin{array}{l}\overline{0.5} \\
179 \\
403 \\
13.7 \\
132 \\
10.0 \\
27 \\
0.7\end{array}$ & $\begin{array}{l}0.3 \\
0.3 \\
0.4 \\
040 \\
140.7 \\
775 \\
25 \\
0.5 \\
-\end{array}$ & $\begin{array}{l}1.0 \\
0.5 \\
7.7 \\
30.7 \\
102 \\
4 \$ 5.8 \\
3.0 \\
1.0 \\
0.1\end{array}$ & 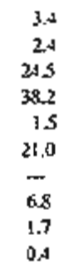 & $\begin{array}{r}- \\
3.0 \\
331 \\
31.7 \\
5.9 \\
17.2 \\
3.7 \\
4.37 \\
1.6 \\
0.2\end{array}$ & 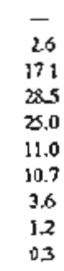 & $\begin{array}{c}-7.8 \\
18.8 \\
27.5 \\
18.5 \\
192 \\
8.6 \\
4.5 \\
1.1\end{array}$ \\
\hline
\end{tabular}

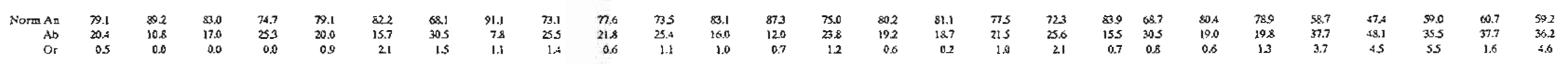


Detailed geologic mapping and petrographic study of the gabbroic rocks intruded by quartz diorite indicates the gabbroic host rocks were metasomatically altered. Near intrusions of quartz diorite, the gabbroic rocks contain much more hornblende than is typical elsewhere, pyroxenes that are parlly replaced by magnesian hornblende, and locally contain minor amounts of interstitial quartz. Near most contacts, a complete gradation is present in these gabbroic rocks from pyroxene with no hornblende, through pyroxene rimmed and partly replaced by hornblende, to hornblende forming some pyroxene pseudomorphs. Plagioclase crystals, whicb are not noticeably zoned in typical gabbroic rocks, are variably zoned in the cootact areas and commonly consist of broad calcic cores and narrower sodic rims. The sodic rims are much more prevalcnt near quartz diorite contacts. The mineralogic changes of gabbroic rocks in the contact zone are reflected in major-oxide analyses (tables 2 and 3; fig. 7). Gabbroic rocks of the Chugach Mountains generally contain <51 percent $\mathrm{SiO}_{2}$; quartz diorites coptain $>62$ weight percent $\mathrm{SiO}_{2}$. The only Jurassic plutonic rocks in the study area to have $\mathrm{SiO}_{2}$ values between $<51$ and 62 weight percent are the gabbroic rocks intruded by quartz diorite (fig. 7). These analytical results support the hypothesis of metasomatic contamination of the mafic bost rock by the intruding quartz diorite.

Greenschist facics alleration of the gabbroic rocks is localized near small fault zones and is abundant near the many faults in the Anchorage C-4 and C-5 Quadrangles and in the southern part of the Nelchina River Gabbronorite. This alteration is characterized by abundant, randomly oriented actinolitic amphiboles which are superimposed on the alteration assemblages discussed abovc. The association of the actinolitic amphiboles and the high-angle faults suggests that the grecnschist facies alteration is a rclatively young event, probably associated with fluid circulation along Cretaccous or early Tertiary faults (see Structural Geology section). The greenschist facics alteration in the Anchorage C-4 and C-5 Quadrangles may be caused by nuids associated with intrusion of the Cretaccous tonalite plutons.

In areas of slight greenschist facies metamorphism, clinopyroxene is replaced by a fibrous, light-green amphibole (actinolitic hornblende?). The dark-green hornblende (a relic of higher temperature alteration of probable Jurassic time) present as rims on some clinopyroxene crystals is not altered. Plagioclase grains are partly altered to clinozoisite. In areas of intense greenschist facics metamorphism, the primary pyroxene crystals and dark-green hornblende are replaced by (wo or three compositions and(or) slightly different generations of fibrous, low-temperature amphiboles which are randomly oriented. Plagioclase grains are completely altered to clinozoisite and(or) epidote and contain minor amounts of actinolitic amphiboles.

Age and Correlation.-Few age determinations have been made on the ultramafic and gabbroic rocks. Five K-Ar ages on hornblende and one on clinopyroxene from gabbroic rocks near the eastern part of the BRUMC range from 154 to $188 \mathrm{Ma}$; only one is younger than $165 \mathrm{Ma}$ (Winkler and others, 1981b). Field relationships support a Jurassic age, as they suggest intrusion of Jurassic-age quartz diorites into the gabbroic rocks while thcy wore still hot enough to be ductile (Burns, 1983, in press). A few older $\mathrm{K}$-Ar ages $(267 \pm 8 \mathrm{Ma}$ and $419 \pm 21 \mathrm{Ma}$ ) on gabbroic rocks from the eastern part of (he BRUMC (Winkler and others, 1981b) have becn attributed to cxcess argon (G. Sisson, written conmun., 1987).

\section{Intermediate Composition Plutonic Rocks}

A voluminous suite of plutonic rocks of intermediate composition is present in the northern Chugach Mountains and extends discontinuously from Kodiak Island to near Tonsing (Hudson, 1979; Flyno and Pessel, 1984). Large plutons are compased of quartz diorite and tonalite, lesser amounts of granodiorite, and very minor trondhjemite (fig. 8; table 3). A few small plutons of quartz monzodiorite and granodiorite intrude the quartz diorite and tonalite in the Anchorage C-5 Quadrangle (Pavlis, 1986). Mafic dike swarms are abundant in the quartz diorite plutons.

Quartz Diorite and Tonalite- Quartz diorite and tonalite are the most abundant intermediate composition plutonic rocks in the northern Chugach Mountains. These rocks occur together and crop out both as large structural blocks bounded by high-angle faults, and as a continuous, relatively intact intrusive complex beneath the Talkectna Formation in the Anchorage C.4 and C.5 Quadrangles (5ig. 3). Dikes, sills, and small plutons of quartz diorite-tonalite intrude the Jurassic-age dioritic and gabbroic rocks, the pre-Jurassic melasedimcntary and metavolcanic rocks, and the Talkcena Formation. Most of the original contacts between Talkeetna Formation and the quartz diorite-tonalite plutons are now obscured by high-angle faults, but intrusive contacts showing this relationship are exposed in the Anchorage C-4 and $\mathrm{C}-5$ Quadrangles. 

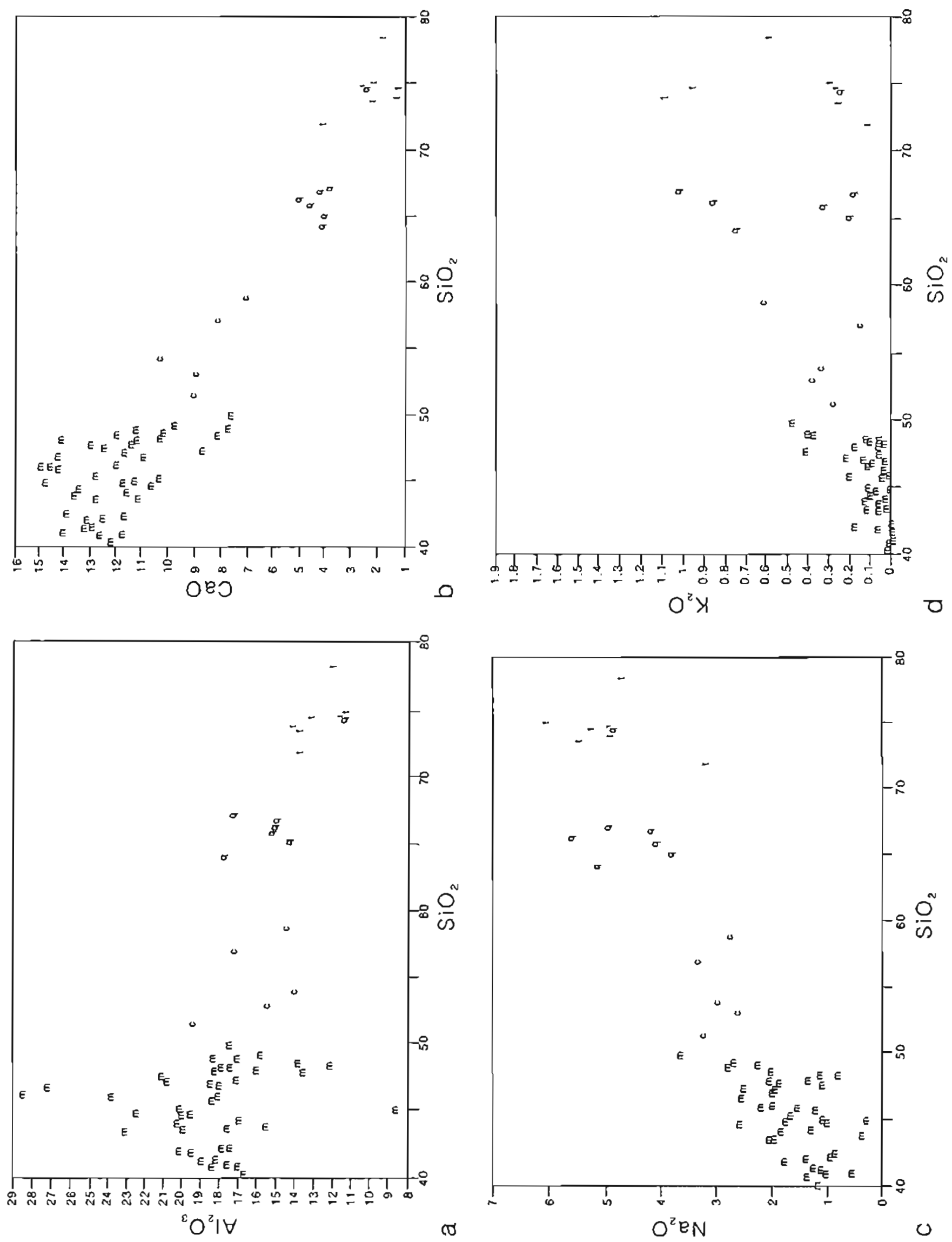

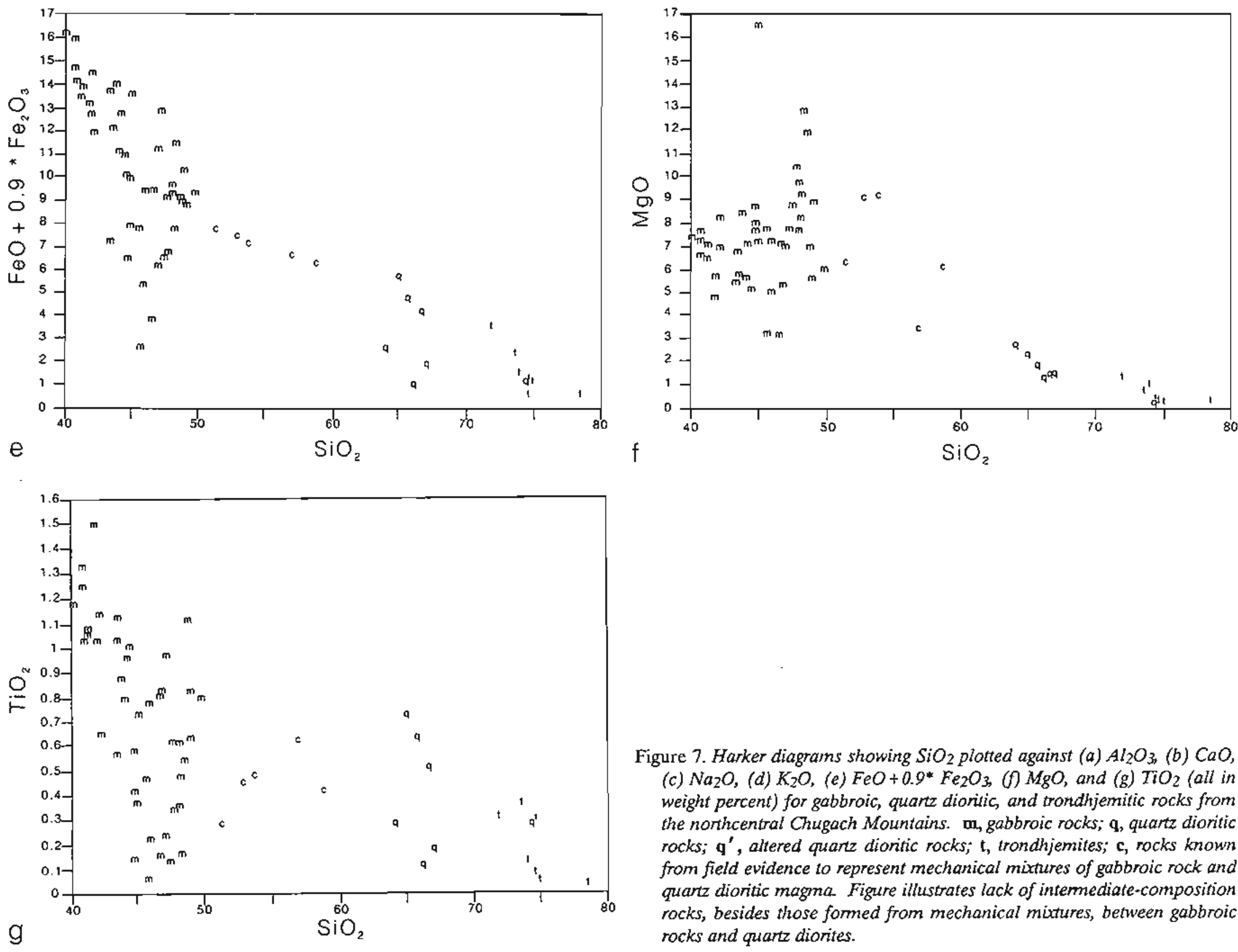

Figure 7. Harker diagrains showing $\mathrm{SiO}_{2}$ plotted against (a) $\mathrm{Al}_{2} \mathrm{O}_{3}$ (b) $\mathrm{CaO}$, (c) $\mathrm{Na}_{2} \mathrm{O}$, (d) $\mathrm{K}_{2} \mathrm{O}$, (e) $\mathrm{FeO}+0.9^{*} \mathrm{Fe}_{2} \mathrm{O}_{3},(f) \mathrm{MgO}$, and (g) $\mathrm{TiO}_{2}$ (all in weight percent) for gabbroic, quant diontic, and trondhjemitic rocks from the northcentral Chugach Mountains. m, gabbroic rocks; q, quartz dioritic rocks; $\mathrm{q}^{\prime}$, altered quantz dionitic rocks; $\mathrm{t}$, trondhjemiles; c, rocks known from field evidence to represent mechanical mixtures of gabbroic rock and quarz dioritic magma Figure illustrates lack of intemediate-composition rocks, besides those formed from mechanical muxtures, between gabbroic rocks and quart diorites. 
Table 3. Major-oxide analyses and CIPW noms on quarz diorile, tonalite, and granodiorile from the northcestral Chugach Mountains

[Analyses performed at Alaska Division of Geological and Geophysical Surveys by N.C. Veach and Kate Bull. FeO* and Fe $2 \mathrm{O}_{3}^{*}$, total molecular re; A. $\left.\left(\mathrm{Na}_{2} \mathrm{O}+\mathrm{K}_{2} \mathrm{O}\right) / \mathrm{Na}_{2} \mathrm{O}+\mathrm{K}_{2} \mathrm{O}+\mathrm{FcO}^{*}+\mathrm{MgO}\right) ; \quad \mathrm{F}, \quad \mathrm{FeO} /\left(\mathrm{Na}_{2} \mathrm{O}+\mathrm{K}_{2} \mathrm{O}+\mathrm{FeO}^{*}+\mathrm{MgO}\right) ; \quad \mathrm{M}, \quad \mathrm{MgO} /\left(\mathrm{Na} 2 \mathrm{O}+\mathrm{K}_{2} \mathrm{O}+\mathrm{P}^{3} \mathrm{O} \cdot+\mathrm{MgO}\right) ; \quad--, \quad n O \mathrm{O}$ applicable; nomm $A n$, an/(an +ab +or); $A b$, ab/(an + ab +or); Or, or/(an+ab+or). Symbols for rock type are as follows: hgb - liomblende gabbro; ahgb - alsered homblende gabbro; agn - altered gabbronorite; qd - quartz dioritc; ton - Ionalitc; aqd - altered quartz diorite)

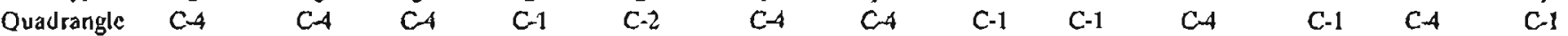

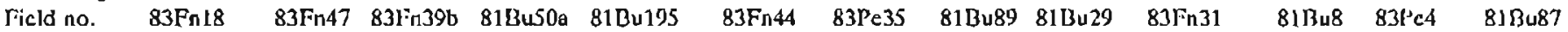

\begin{tabular}{|c|c|c|c|c|c|c|c|c|c|c|c|c|c|}
\hline \multicolumn{14}{|c|}{ Chemical analyses (weight pcrcent) } \\
\hline $\mathrm{SiO}_{2}$ & 51.28 & 52.83 & 53.77 & 56.88 & 58.64 & 62.05 & 64,07 & 64.96 & 65.71 & 66.13 & 66.65 & 66.95 & 74.39 \\
\hline $\mathrm{Al}_{2} \mathrm{O}_{3}$ & 19.57 & 15.67 & 14.05 & 17.44 & 14.46 & 15.32 & 18.02 & 14.49 & 15.43 & 15.10 & 15.13 & 17.56 & 11.63 \\
\hline $\mathrm{FeO}$ & -- & - & - & 3.85 & 4.27 & - & - & 3.38 & 2,48 & - & 2.64 & - & 0.69 \\
\hline $\mathrm{F}_{2} \mathrm{O}_{3}$ & -- & - & - & 3.20 & 2.35 & - & - & 2.72 & 2.67 & - & 1.97 & $\cdots$ & 0.71 \\
\hline $\mathrm{MgO}$ & 6.39 & 9.13 & 9.20 & 350 & 6.14 & 1.79 & 2.73 & 2.38 & 1.94 & 1.36 & 1.54 & 1.59 & 0.40 \\
\hline $\mathrm{CaO}$ & 9.17 & 9.11 & 10.49 & 8.28 & 7.23 & 6.14 & 4.35 & 4.33 & 4.83 & 5,17 & 4.46 & 4.01 & 2.63 \\
\hline $\mathrm{Na}_{2} \mathrm{O}$ & 3.25 & 2.65 & 3.01 & 3.34 & 2.75 & 4.74 & 5.18 & 3.90 & 4.17 & 5.66 & 4.26 & 5.02 & 4.91 \\
\hline $\mathrm{K}_{2} \mathrm{O}$ & 0.29 & 0.39 & 0.35 & 0.17 & 0.62 & 1.68 & 0.77 & 0,22 & 0.35 & 0.88 & 0.20 & 1.04 & 0.26 \\
\hline $\mathrm{TiO}_{2}$ & 0.29 & 0.46 & 0.49 & 0.64 & 0.43 & 0.21 & 0.30 & 0.74 & 0.65 & 0.13 & 0.53 & 0.20 & 0.30 \\
\hline $\mathrm{P}_{2} \mathrm{O}_{5}$ & 0.04 & 0.06 & 0.05 & 0.14 & 0.08 & 0.08 & 0.09 & 0.22 & 0.19 & 0.06 & 0.15 & 0.08 & 0.08 \\
\hline $\mathrm{M} \aleph$ & 0.20 & 0.18 & 0.17 & 0.16 & 0.13 & 0.04 & 0.06 & 0.17 & 0.12 & 0.03 & 0.15 & 0.05 & 0.03 \\
\hline I.OI & 1.46 & 1.73 & 1.06 & 0.78 & 1.97 & 6.36 & 1.86 & 1.38 & 0.77 & 4.01 & 1.04 & 1.38 & 3.11 \\
\hline $\mathrm{IC}_{2} \mathrm{O}_{3} *$ & 8.62 & 8.33 & 8.00 & $\cdots$ & $\cdots$ & 1.70 & 3.12 & $\cdots$ & - & 1.32 & - & 2.33 & - \\
\hline TOTAL & 100.56 & $\overline{100.54}$ & 100,64 & 98.38 & 99.07 & 100.11 & 100.55 & 48,89 & 99.31 & 99.85 & $\overline{98.72}$ & $\overline{100.21}$ & 99.14 \\
\hline$\Gamma \mathrm{cO} / \mathrm{MgO}$ & 1.2 & 0.8 & 0.8 & 1.92 & 1.04 & 0.85 & 1.03 & 2.45 & 2.51 & 0.87 & 2.86 & 1.32 & 3.32 \\
\hline$A$ & 20.0 & 15.5 & 17.0 & 25.6 & 21.2 & 65.9 & 51.8 & 33.4 & 39.9 & 72.0 & 42.8 & 62.2 & 75.0 \\
\hline F & 43.8 & 38.1 & 36.4 & 49.0 & 40.2 & 15.7 & 24.4 & 47.3 & 43.0 & 13.0 & 42,4 & 21.5 & 19.2 \\
\hline$M$ & 36.2 & 46.5 & 46.6 & 255 & 38.6 & 18.4 & 23.8 & 19.3 & 17.1 & 15.0 & 14.8 & 16.3 & 5.8 \\
\hline \multicolumn{14}{|c|}{ CIPW norms (weight percent) } \\
\hline$q(z$ & - & 2.4 & 1.4 & 14.7 & 16.0 & 16.6 & 18.0 & 28.6 & 27.2 & 20.4 & 29.2 & 23.3 & 41.1 \\
\hline or & 1.7 & 2.3 & 2.1 & 1,0 & 3.8 & 10.6 & 4.6 & 1.3 & 2.1 & 5.4 & 1.2 & 6.2 & 1.6 \\
\hline ab & 27,9 & 22.8 & 25.7 & 29,0 & 24.0 & 42.8 & 44.5 & 33.8 & 35,8 & 50.0 & 36.9 & 43.0 & 43.3 \\
\hline an & 38,6 & 30.3 & 24.0 & 329 & 26.0 & 16.6 & 21.3 & 20.6 & 22.7 & 13.8 & 23.6 & 19.6 & 9.3 \\
\hline di & 6.0 & 12.4 & 22.6 & 6.7 & 8.3 & 10.3 & - & - & 0.3 & 7.6 & - & - & 2.7 \\
\hline hy & 20.7 & 25.9 & 20.2 & 9.5 & 17.4 & - & 7.2 & 9.2 & 6.3 & - & 6.6 & 4.0 & - \\
\hline ol & 1.7 & - & - & $\cdots$ & -- & - & - & - & - & -.. & - & - & -.- \\
\hline$m I$ & 2.6 & 2.9 & 2.9 & 4.8 & 3.5 & - & 2.6 & 4.0 & 3.9 & $\ldots$ & 2.9 & 1.4 & $1 . t$ \\
\hline il & 0.6 & 0.9 & 0.9 & 1.2 & 0.8 & 0.1 & 0.6 & 1.4 & 1.3 & 0.1 & 1.0 & 0.4 & 0.6 \\
\hline ap & 0.1 & 0.1 & 0.1 & 0.3 & 0.2 & 0.2 & 0.2 & 0.5 & 0.4 & 0.1 & 0.4 & 0.2 & 0.2 \\
\hline $\operatorname{cor}$ & - & - & - & $\cdots$ & - & - & 1.0 & 0.5 & - & $\cdots$ & 0.2 & 1.1 & - \\
\hline hnı & - & - & - & -- & - & 1.8 & -- & - & - & 1.4 & - & 0.7 & - \\
\hline sph & -- & - & - & --- & - & 0.4 & - & - & -- & 0.2 & - & - & - \\
\hline wo & - & - & - & $\cdots$ & - & 0.6 & - & - & -- & 1.0 & - & - & 0.1 \\
\hline Norm An & 56.5 & 54.6 & 46.4 & 52.3 & 48.4 & 23.7 & 30.3 & 36.9 & 5.9 & 19.9 & 36.2 & 28.5 & 17.2 \\
\hline$\Lambda \mathbf{b}$ & 40.9 & $\$ 1.2$ & 49.6 & 46.1 & 44.6 & 61.1 & 63.2 & 60.7 & 93.5 & 72.2 & 61.7 & 625 & 79.9 \\
\hline Or & 2.6 & 4.2 & 4.0 & 1.6 & 7.0 & 15.1 & 6.6 & 2.4 & 0.5 & 7.8 & 2.0 & 9.0 & 3.0 \\
\hline
\end{tabular}




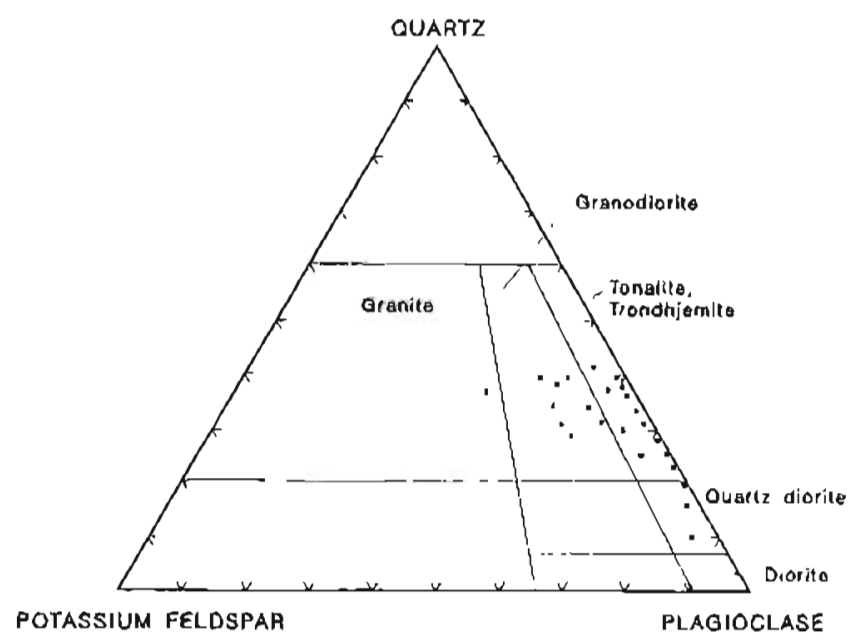

Figure 8. Teniary diagram showing modal percentages of quantz-plagioclase-polassium-feldspar of the quartz diorile-tonalite pluton in the Anchorage C-3 quadrangle. The pluton is typical of those mapped as quantz diorite-tonalite in the nonhcentral Chugach Mountains. Tick-marks indicare 10-percent inlervals. (From Flynr, unpub. dala.)

The quartz diorite and tonalite are typically medium grained, relatively homogeneous in composition and texture, and contain locally abundant patches and trains of xenoliths of more mafic Jurassic plutonic rocks. The quartz diorise and tonalite are typically composed of 45 to 65 percent plagioclase, 10 to 35 percent strained, anhedral quartz, and 15 to 25 percent hornblende. Anhedral biotite commonly forms 1 to 2 percent of the rock; apatite, iron-oxides, zircon, and sphene arc present in trace amounts. Locally, interstitial fine-grained crystals of potassium feldspar constitute $<2$ percent of the rock.

Plagioclase grains are subhedral $(0.5$ to $2.5 \mathrm{~mm})$ and display normal zoning, with andesine cores and oligoclase rims; the cores are commonly altered to assemblages of clinozoisite, cpidote, and sericite. Quartz grains are anbedral to subhedral $(0.5$ to $2.5 \mathrm{~mm}$ ) with undulatory extinction, and some crystals have interlocking boundaries. Hornblende grains are mostly anhedral to subhedral $(0.5$ to $3.0 \mathrm{~mm}$ ) and display green and ycllow pleochroism. Less commonly, hornblende is blue grcen to light green, and seems to be associated with lowtemperature alteration. In more mafic quartz dioritc, hornblende is poikilitic, enclosing subhedral quartz and plagioclase crystals. Relict clinopyroxene forms the cores of some large hornblende grains in more mafic quartz diorite. Biotite grains are anhedral $(0.5$ to $3.0 \mathrm{~mm})$ with dark-brown to light- brown pleochroism. Biotite grains form adjacent to opaque minerals and are partially to completely replaced by chlorite and sphene in most rocks.

Zones of highly altered, cataclastic quartz diorite and tonalite are common along many of the fault zones. Rocks in these zones contain abundant finegrained, recrystallized quartz; mafic minerals are completely replaced by chlorite, and plagioclase is partially to completely repiaced by epidote and sericite. Other alteration assemblages in these areas include prebrite \pm epidote \pm carbonate \pm laumontite and secondary quartz.

Granodiorite within Quartz Dlorite-Tonalite Plutons.-Minor amounts of pink-weathering granodiorite (with 10 to 15 percent alkali Feldspar) are present in the quartz diorite and tonalite plutons, and are too small to show on the map (sheets 1 and 2). Contacts between the granodiorite and the quartz dioritc and tonalite are generally gradationa!, but small dikes of granodiorite do intrude the quartz diorite and tonalite. Pegmatitic dikes composed of potassiur feldspar and quartz associalcd with granodiorite also intrude the quartz dioritic plutons. The granodiorite is located in the upper parts of the quartz diorite-tonalite plutons and may be a latestage differentiate or a younger, unrclated intrusion.

Granodiorite is generally massive, medium grained, and hypidiomorphic-granular to porphyritic. Quartz grains are commonly dendritic with myrmekitic intergrowths of plagioclasc. The dominant mafic phase is biotite, which makes up about 5 percent of the rock. Biotite is partially to completely replaced by chlorite. Trace amounts of green hornblende, apatite, and zircon are also present. Plagioclase is heavily sericitized. Secondary epidote forms granular masses and large, radiating bladed grains along fractures.

Small Plutons of Quartz Monzodiorite and Granodiorite.-Small plutons ( $<5 \mathrm{~km}^{2}$ ) ranging in composition from quartz monzodiorite to lesser granodiorite intrude quartz diorite and tonalite in the Anchorage C-5 Quadrangle (Pavlis, 1982A, 1983). Most of the quartz monzodiorite and granodiorite bodies are roughly circular or elliptical with some irregular lobes. The plutons clearly intrude surrounding rocks, but no chilled margin or contact aureole was recognized adjacent to the bodies (Pavlis, 1986).

The rocks are fine to medium grained and hypidiomorphic-granular; they generally contain both hornblende and biotite. Mafic phases and quartz contents are 10 to 20 percent each. Plagioclase is 
zoned, which suggests either cooling at relatively shallow crustal levels (Pavlis, 1982a, 1983) or changing magmatic conditions, including fractionation and mechanical processes (for example, Morse, 1980).

Age and Correlation.-K-Ar age determinations on hornblende and biotite from the quartz diorites, tonalites quartz monzodiorites and mafic dikes indicate Jurassic ages (160 to $194 \mathrm{Ma}$ ) (table 4). A K-Ar whole-rock analysis on a mafic dike intruding quartz diorite yiclds an age of $130 \mathrm{Ma}$ (table 4; Winkler and others, 1990).

These agcs determined from the intermcdiate rocks coincide with ages reported from the Talkeetna-Aleutian Rangc batholith and the KodiakKenai plutonic belt (Csetjey and others, 1978; Hudson, 1979). Other similarities between the
Talkeetna-Aleutian Range batholith, the KodiakKenai plutonic belt, and the plutonic rocks of intermediate composition in the northern Chugach Mountains include rock type and relative abundances, regional setting, composition, and petrography. These similarities suggest that the quartz diorite and related rocks exposed in the northern Chugach Mountains may be the edge of the Talkeetna-Alcutian Range batholith, which has been disrupted by Late Cretaceous(?) and Tertiary faulting.

\section{INTERPRETATION}

The cumulate ultramafic and gabbroic rocks of the BRUMC are interpreted by Burns (1985) and Newberry and others (1986) to represent the

Table 4. $K-A r$ (mineral and whole-rock) and U-Pb (zircon) ages from intemediate compositon plutonic rocks of Jurassic age from the northcentral Chugach Mountains

[Analytical work for this study done under the direction of D.L Turner, Universily of Alaska Geophysical Institute, Pairbanks, Alaska. Rock types given as in previous publications. Abbreviations include: hb-homblende; bio-biotite; qtz-quarcz; dio-diositc; cglm - conglomerate; ton - tonalitc; - no data]

\begin{tabular}{|c|c|c|c|c|c|c|c|}
\hline Sample no. & Unit & Rock & $\begin{array}{c}\text { Mineral } \\
\text { dated }\end{array}$ & $\begin{array}{l}\text { Age } \\
(m . y .)\end{array}$ & $\begin{array}{l}\% \mathrm{~K}_{2} \mathrm{O} \\
\text { average }\end{array}$ & Quadrangle & Reference \\
\hline Paulis F & Jdg & Hb glz dlo & Hornblende & $194 \pm 7$ & - & C.5 & Paulis (1983) \\
\hline Paulis $\mathrm{E}$ & Idg & Ilb giz dio & Hormblendc & $191 \pm 7$ & - & C-5 & Pavlis (1983) \\
\hline Pavis G & $J d g$ & Hb dio & Homblendc & $189 \pm 8$ & - & C-5 & Pavis (1983) \\
\hline $82 \mathrm{Fn} 255 \mathrm{~b}$ & $\mathbf{J d g}$ & Qtz dio & Biotite & $187.3 \pm 5.6$ & 0.600 & $\mathrm{C}-3$ & This study \\
\hline 79AH38 (AK319) & Jdg & Qtz dio & Zircon & 183 concordant & - & c.5 & Hudson \& Arth (1989) \\
\hline $82 F_{n} 1138$ & - & Qtz dio & Biotite & $182.8 \pm 5.5$ & 2.423 & C.3 & This study \\
\hline $82 \mathrm{~F} n 255 \mathrm{a}$ & - & Qtz dio & Homblende & $181.4 \pm 5.4$ & 4.352 & - & This seudy. \\
\hline \multirow[t]{2}{*}{ 81AWk14 } & Jqd & Ho bio ton & Homblende & $181 \pm 8$ & 0.440 & C.3 & Winkler (1989) \\
\hline & & & Biotite & $172 \pm 5$ & 0.432 & & mineral palr \\
\hline $82 \mathrm{~F} n 2028-2$ & - & Qtz dio & Biotite & $177.5 \pm 5.3$ & 2.700 & - & This study \\
\hline $82 P_{n} 120 b$ & - & Qtz dio & Biotite & $178.4 \pm 5.4$ & 1.368 & $C-3$ & This sludy \\
\hline $82 F_{n} 111 a$ & - & Qtz dio & Ilomblende & $177.8 \pm 5.3$ & 0.450 & C-3 & This study \\
\hline 74AH56 (AK336) & $\mathrm{Jg}$ & Hb dio & Hornblende & $177 \pm 11$ & - & $\mathrm{C}-1$ & Hudson A Arth (1989) \\
\hline 82Le $c-11$ & - & Shale cglm clast & Hornblende & $177.1 \pm 5.3$ & 0.600 & $\mathrm{C}-2$ & This study \\
\hline \multirow[t]{2}{*}{ 81AWk34 } & Jgd & Hb bio ton & Hornblende & $175 \pm 8$ & 0.421 & C.5 & Winkler (1989) \\
\hline & & & Biotitc & $374 \pm 5$ & 5.88 & & mincral pair \\
\hline 81.JD874a & - & Otz dio & Hornbtende & $174.3 \pm 5.2$ & 0.298 & $c-2$ & This seudy \\
\hline T9AHS2 (AK332) & $\mathrm{Jdg}$ & Ib dio & Hornblende & $172 \pm 11$ & $\ldots$ & C.5 & Winkler (unpub. dala) \\
\hline 79A1336 (AK317) & $J d g$ & Qtz dio & Zircon & 171 & - & $\mathrm{C}-5$ & Iludson \& Arth (1989) \\
\hline 76AHL58 (AK338) & Jqd & Ho gtz dio & Hornblende & $107 \pm 10$ & - & D-1 & Hudson \& Arth (1989) \\
\hline $82 \mathrm{Fn} 120 \mathrm{a}$ & - & Qtz dio & Hornblende & $166.5 \pm 5.0$ & 0.287 & C-3 & This study \\
\hline SHB Glark & $J d g$ & Ho bio q12 dio & Biotite & $167 \pm 9$ & - & B-6 & Clark (1972) \\
\hline 79 AH34 (AK316) & $\mathrm{Jdg}$ & Hlb qtz dio & Hornblende & $167 \pm 9$ & - & $C-6$ & Hudson \& Arth (1989) \\
\hline $79 \mathrm{AH} 40(\mathrm{AK} 320)$ & $J d g$ & Hb qtz dio & Hornblende & $165 \pm 10$ & - & $C-4$ & Winkler (unpub. daca) \\
\hline $82 \mathrm{Fn} 113 \mathrm{a}$ & $\mathrm{Jdg}$ & Qtz dio & Homblende & $163.6 \pm 4.9$ & 0.363 & C-3 & This sludy \\
\hline $82 F n 111 b$ & Jdg & Qtz dio & Biotite & $161.0 \pm 4.8$ & 2.947 & C-3 & This study \\
\hline $82 F \operatorname{n} 202 a-1$ & $\mathrm{Jdg}$ & Qtz dio & Hornolende & $160.0 \pm 4.8$ & 0.425 & - & This study \\
\hline \multicolumn{8}{|l|}{ Mafic dikes } \\
\hline $81 \mathrm{AWk} 49 \mathrm{a}$ & $\mathrm{TJa}$ & Basaltic dike & Whole rock & $130 \pm 6$ & - & $D-4$ & Winkder (unpub. data) \\
\hline
\end{tabular}


fractional crystallization product of magma(s) that produced the Talkeetna Formation volcanic rocks. This interpretation is based on mineralogy and petrology of the ultramafic and gabbroic rocks and of the volcanic rocks.

Magma from the quartz dioritic intrusions may bave erupted and formed intermediate silicic to siliceous volcanic rocks, but the bulk of these volcanic rocks, if they existed, has apparently been removed by erosion. The majority of the Talkeetna Formation appears to be basaltic to andesitic in character, and is thus more mafic than the quartz diorite and tonalite. Additionally, the intrusive relationship of the quartz diorite-tonalite into Talkeetna Formation volcanic rocks indicates that the large quartz diorite-tonalite plutons are younger than the Talkeetna Formation in the northern Chugach Mountains. Therefore, we propose that the quartz diorite-tonalite is not the intrusive equivalent of volcanic rocks in the Talkeetna Formation.

The quartz dioritic rocks also always intrude the gabbroic rocks. Abundant ductile deformation of adjaccnt quartz dioritic and gabbroic rocks (Burns, 1983 , in press) and similar K-Ar ages for quartz dioritc and gabbroic rocks suggest that the intrusions of quartz diorite and gabbroic rocks are broadly contemporaneous.

Ar attempt was made during this study to select a continuous compositional suite of samples ranging from gabbronorite to quartz diorite for major-oxide analysis. Petrographic study and field relationships, combined with analytical results, indicate that the diorite plutons which have been mapped by other workers in the Anchorage C-4 and C-5 Ouadrangles (Clark, 1972b; Pavlis, 1983, 1986) appear to have formed (in most instances) by mixing partially solidified gabbroic and molten quartz dioritic magmas (see Little and others, 1986b). Only minor amounts of the diorite appear to have formed as a straight differentiate of the gabbroic magma or as a mafic fractionate of the quartz dioritic magma. It would therefore appear that the more differentiated quartz diorite magma is also not a differentiate of the magma that formed the gabbroic rocks.

This study then supports the interpretation of Burns (1985) that the quartz diorite-tonalite probably crystallized from a different magma than the one that produced the gabbroic rocks, on the basis of petrology, mineralogy, and compositional data. We suggest a less conventional petrogenetic mechanism than fractional crystallization for formation of the quartz dioritic rocks, such as analexis of preexisting oceanic crust, although we have not quantitatively tested such a modcl.

\section{CRETACEOUS SEDIMENTARY ROCKS}

\section{MATANUSKA FORMATION}

The Matanuska Formation, a marine sequence of clastic sedimentary rocks ( $\mathrm{Km}$, sheets 1 and 2 ), is the only Cretaccous age sedimentary sequeace north of the Border Ranges fault in the Nelchina-Kings Mountain region. The Matanuska Formation was deposited unconformably on rocks of the Peninsular terrane and crops out in the northernmost edge of the central Cbugach Mountains, in the Matanuska Valley, and in the southern Talkeetna Mountains (Grantr, 1961a,b; Barnes, 1962; Csetjey and others, 1978) (figs. 1 and 2). The outcrops in the Chugacb Mountains occur along the faulted southern limb of the Mataruska Valley synclinorium and generally dip moderately or steeply to the north or northwest (Grantz, 1961a,b). Clastic detritus in the Matanuska Formation is apparently derived from erosion of Jurassic are rocks of the Peninsular terrane (Grantz, 1964).

The Matanuska Formation consists chiefly of fine-laminated dark-gray claystone and siltstone, with subordinate grecnish-gray lithic and arkosic sandstone, and minor conglomerate and conglomicratic mudstone and sandstone (Grantz, 1964). Sole markings, flame structure, graded bedding and other features indicative of turbidite deposition are abundant in the formation, particularly in the Matanuska Valley.

\section{Petrology and Lithology}

Along the north Mank of the central Chugach Mountairs, the Matanuska Formation consists chicfly of a homogeneous, thick sequence of wellindurated, fissile, medium- to dark-gray claystone and mudstone. These mudstones are fine-laminated locally and contain some thin, laterally continuous interbeds of siltstone and fine sandstone (Little and others, 1986b). Reddish-weathering concretions and lenses of sandy limestone as thick as $30 \mathrm{~cm}$ within the dark mudstone contain cone-in-cone structures. These rocks are probably equivalent to the Campanian-Maestrichtian unit recognized to the east and north (unit Kms of Grantz, 1961a,b). Unlike Grantz's (1961b) Kms unit in the Matanuska Valley, which contains abundant channelized lenses of conglomerate and sandstone, the exposures in the northern Chugach Mountains consist predominantly of mudstone with only minor interbedded sandstone. These shaly rocks may have been deposited in a 
more distal basin-plain environment than those in the Matanuska Valley described by Grantz (1964), which would suggest southward transport.

Along the Chugach range front in the Anchorage D-2 Quadrangle, the base of the Matanuska Formation consists of Cenomanian or Turonian age pebbly sandstone that is overlain by a unit of Turonian age siltstone, interbedded siltstone and graded sandstone beds, sandstone, and conglomerate (Grantz, 1961b). These Cenomanian-Turonian rocks are overlain by the Campanian-Maestrichtian unit (Kms) of Grantz (1961a,b) described below and were not recognized west of the Matanuska Glacier.

In the Matanuska Vallcy (Waring, 1936; Barnes and Payne, 1956; Grantz, 1961a,b) and along the nortb flank of the Chugach Mountains, the Matanuska Formation is unconformably overlain, with only minor angular discordance, by fluvial sedimentary rocks of the Paleocene Chickaloon Formation. This disconformity in the northern Chugach Mountains is well exposed in the Anchorage D-3 Quadrangle in the canyons between O'Brien and Gravel Creeks, and on Coal Creek in the Anchorage D-4 Quadrangle (Little and others, 1986b).

Although the lower contact of the Matanuska Formation is commonly covered or faulted, there are sevcral localities in the Nelchina-Kings Mountain region where a depositional conlact is exposed. The Matanuska Formation overlies volcanic rocks of the Lower Jurassic Talkeetna Formation in several places east of Wolverine Creck (Capps, 1927; Grantz, 1961a,b; Lillle and others, 1986b), and to the wesl of the map area, overlies the Upper Jurassic Naknek Formation at one location along Wolverioe Creek (Anchorage C-6 Quadrangle, fig. 3) (Grantz, 1964).

In lower Wolverine Creek (Anchorage C-6 Quadrangle; fig. 3), late-early or late Albian age rocks of the Matanuska Formation unconformably overlie siltstone of the Upper Jurassic Naknek Formation (Grantz, 1964). At this location, the basal Matanuska Formation consists of $10 \mathrm{~m}$ of pebbly (locally containing boulders), coarse-grained volcaniclastic sandstone that grades upward into pebbly, finc-grained sandstones containing sandy limestone concretions (Grantz, 1964). These poorly sorted rocks are overlain by about 70 on of dark grecnish-gray to medium-dark-gray silty claystone containing thin and medium interbeds of sandstone near the top of the sequence. Above the claystone and siltstone, $13 \mathrm{~m}$ of thick-bedded, dark greenishgray, fine- and mediurn-grained volcaniclastic sandstone of Albian age represent the uppermost rocks exposed. This section locally contains glauconite and was probably deposited in littoral and nearshore environments (Grantz, 1964).

To the east of Wolverine Creek, the Matanuska Formation unconformably overlies the Lower Jurassic Talkeetna Formation. Near Riley Creek (Anchorage D-4 Quadrangle), the basal Matanuska Formation consists of about $25 \mathrm{~m}$ of volcaniclastic sandstone and pebble conglomerate overlain by about $80 \mathrm{~m}$ of dark-olive-gray and dark-gray siltstone and thin beds of greenish-gray fine-grained sandstone (Granth, 1964). These two clastic units of Albian age are derived chicly from underlying volcanic rocks of the Talkeetra Formation (Capps, 1927; Grantz, 1964). Rocks similar to the gray siltstone and sandstone unit described above overlic the Talkeetna Formation along the range front east of Ninemilc Crcek (Anchorage D-4 Quadrangle; Grantz, 1964). In the Anchorage D-1 Quadrangle, basal beds of the Matanuska Formation (Albian) consist of conglomerate and crossbedded sandstone that grade upward into sandstone which is overlain by interbedded siltstone and sandstone (Grantz, 1961a). These beds are in Iurn overlain by hard siltstone and claystone (Grant' 1 1961a).

The basal unconformity of the Matanuska Formation is well-exposed on the Chugach range front between Coal and Carbon Creeks (Anchorage D-4 Quadrangle), where it has about $1 \mathrm{~m}$ of local erosional rclief (Little and others, 1986b). Lithic lapilli asb tuff of the Talkeetna Formation is overlain by about $3 \mathrm{~m}$ of dark greenish-gray, very poorly sorted pebble cunglomerate with a coarse-grained sandy matrix containing subangular clasis $(1010 \mathrm{~cm}$ diam) from the underlying Talkeetna Formation (Little, 1988; Little and others, 1986b). These rocks are in fault contact with about $7 \mathrm{~m}$ of brown mudstone. The mudstone is, in turn, overlain by a 20- to 30-m-thick sequence of medium- to thickbedded olive-green siltstone and fine-grained sandstone resembling Grantz's (1964) description (above) of the claystone and siltstonc unit.

\section{Age and Correlation}

The Matanuska Formation contains fossils of Albian and Maestrichtian ages (middle to Late Cretaceous) and is part of an elongate belt of clastic sedimentary rocks of dominantly marine origin that exends from the Canadian border to the Alaska Peninsula (Grant2, 1964). This belt overlaps the Wrangellia and Peninsular terranes (Jones and Silberling, 1979). On the Alaska Peninsula, correlative Late Cretaceous rocks of the Peninsular 
terrane are included in the Chignik and Hoodoo Formations (Mancini and others, 1978).

\section{Interpretatlon}

The Matanuska Formation consists of both shallow and deep marine sedimentary rocks. Grantz (1964) concluded that the shoreline during Campanian-Maestrichtian time was only several miles north of the present day Matanuska Valley and that, at least at certain times, a southern shoreline may also bave existed in the present Cbugach Mountain area. If this is true, then the transition from a nearshore to relatively deep marine environment was abrupt. This observation, together with the occurrence of several unconformities in the Matanuska Formation, some of then angular (Grantz, 1964), suggests tectonic instability during deposition of the Matanuska Formation.

Late Cretaccous-Early Tertiary age plutonic and volcanic igneous rocks representing a calc-alkaline magmatic arc coeval with the Matanuska Formation are located north of the Matanuska Formation in the Alaska-Aleutian Range and in the Talkeetna Mountains (Fisher and Magoon, 1977; Hudson, 1979). The Chugach terrane, which is gencrally interpreted as an Early to Late Cretaceous subduction complex (Nilsen and Zuffa, 1982) lies south of the beit of Upper Cretaceous sedimentary rocks. This spatial relationship between the three cocval convergent margin tectonic elements led Moore (1973) and Fisher and Magoon (1977) to interpret the Upper Cretaceous part of the Matanuska Formation as a lorearc basin deposit associated with a north-dipping subduction zone along what is now the southern margin of Alaska.

\section{DESCRIPTIVE GEOLOGY OF THE CHUGACH TERRANE}

\section{CRETACEOUS SYSTEM}

The Chugach terrane (Berg and others, 1972) of Cretaccous age is exposed continuously for $2,000 \mathrm{~km}$ along the southern rim of Alaska and represents one of the best-preserved ancient subduction complexes in the world (fig. 1) (Nison and Zuffa, 1982). The Chugach terrane is the most landward, uplifted portion of a wide accretionary prism which becomes generally younger toward the sea. Low-grade metamorphic rocks of the Chugach terranc have been subjected to a complex sequence of ductite and brittle deformational events, which began during initial accretion to the edge of the continental island arc margin and which continued as the subduction complex accreted southward.

In the Nelchina-Kings Mountain area, the Chugach terrane is composed of an older melange known as the McHugh Complex and a younger flysch-like sequence known as the Valdez Group. The McHugh Complex contains mafic volcanic rocks, and basin and trench-slope(?) deposits, all deformed into a tectonic melange. The Valdez Group consists chiefly of trench-fill turbidites and mudstone. In some areas, highly deformed, dark-gray metasedimentary rocks (argillite) in the McHugh Complex are difficult to distinguish from similar rocks in the Valdez Group. Generally, bowever, McHugh Complex rocks were distinguished from Valdez Group rocks on the basis of these criteria: (1) argillaceous rocks are typically slaty or phyllitic in the Valdez Group, and have a less penetratively deformed, more chaotic texture in the McHugh Complex; (2) green metatuff lenses and thin "wispy" layers of green tuffaceous malcrial are typical of the McHugb Complex, but gencrally absent in the Valdez Group; (3) where tuff is present in the Valdez Group, it tends to be interlayered with argillite (possibly original sedimentary layering) and is traceablc for hundreds of meters, whereas tuff in the McHugh Complex is typically finely and chaotically intermixed with argillite; (4) exotic blocks of marble, chert, pillow lavas, and scrpentine occur locally io the McHugh Complex, but are absent in the Valdez Group; and (5) fold geometry is more systematic and folds more easily recognized in the Valdez Group than in the McHugh Complex.

\section{MCHUGH COMPLEX}

The McHugh Complex, a melange composed of blocks of various ages in a highly deformed matrix of argillite, graywacke, and (uff, was named by Clark (1973) for a cbaotic assemblage of weakly metamorphosed sedimentary and volcanic rocks exposed in the Chugach Mountains between Turnagain Arm and the Knik River. Winkier and others (1981b) assigned a similar assemblage in the Valdez Quadrangle to the McHugh Complex. Our mapping in the Nelchina-Kings Mountain area shows the McHugh Complex occurs in irregular fault. bounded blocks between the Border Ranges fault system and the Eagle River thrust (sheets 1 and 2), and thus forms a link between the type area near Anchorage defined by Clark (1973) and the rocks mapped by Winkler and others (1981b) in the Valdez Quadrangle.

The McHugh Complex is in fault contact with the Valdez Group (Kvs) to the south and with rocks of 
the Peninsular terrane to the north. The northern boundary of the McHugh Complex has been referred to as the Border Ranges fault (MacKevelt and Plafker, 1974). In the Nelchina-Kings Mountain area, the Border Ranges fault system extends in an arcuate (concave to the southeast) pattern across the region and consists mainly of a series of steeply dipping high-angle faults. Motion on the faults appears to have been dominated in early Tertiary time by extensional and dextral strike-slip displacement. Vestiges of an earlier, probably Early Cretaceous age, north-dipping thrust boundary between the Peninsular and Chugach terranes are locally preserved. These thrust zones are now crosscut by Tertiary high-angle faults that dominate the present structural grain of the Chugach range. The southern boundary of the McHugh Complex is the regionally north-dipping Eagle River thrust, which places the McHugh Complex on top of the Valdez Group to the south. Locally, this fault has been cut by younger, high-angle faults, or bas been rotated to a nearly vertical position.

\section{Petrology and Lithology}

In the Nelchina-Kings Mountain area, the McHugh Complex is composed of argiltite, graygreen metatuff, thinly interlaminated gray and green phyllite, graywacke, chert, pillow basalt, and lesser marble. Composition varies from dominantly metatuff to dominantly argillite. Chaotic mixtures of light-green metaluff and dark-gray argillite are common in the McHugh Complex and were presumably formed, at least in part, by soft-sediment deformation. The complex commonly contains a block and matrix (melange) fabric, with a scaly foliation defined by pervasive shear fractures.

The McHugh Complex is mapped as six units on sheets 1 and 2: (1) mctavolcanic rocks, (2) predominantly metavolcanic rocks, (3) metasedimentary rocks, (4) predominantly metasedimentary rocks, (5) cataclasite, and (6) undifferentiated McHugh Complex.

The metavolcanic rock unit of the McHugh Complex (Kmv; sheets 1 and 2 ) is massive, medium green or slightly bluish green. These rocks consist of light-green, weakly foliated metatuff that is locally interlayered or chaotically intermixed with minor amounts of dark-gray argillite. Locally, the unit contains blocks of recrystallized marble and bedded chert as large as several meters. The rocks arc commonly highly shattered and locally have abundant tectonically polished and slickensided surfaces.
The metasedimentary rock unit $(\mathrm{Kms})$ of the McHugh Complex consists of dark-gray argillite and scaly argillite. The unit contains bodies of graywacke and(or) chert and local leases of metatuff.

The predominantly metavolcanic rock unit (Kmxv) is gradational in composition berween the metavolcanic unit (Kmv) and the metasedimentary unit (Kms) and consists of 50 to 80 percent metavolcanic rock. The unit consists chiefly of lightgreen, weakly to moderately foliated metatuff interlayered and chaotically intermixed with dark. gray argillite. The unit is commonly massive, with a fabric characterized by swirls of green and gray. Layered metatuff commonly has a detrital clastic texture and contains abundant mud-chip rip-ups, suggesting transportation by submarine mass-llow mechanisms.

The predominantly metasedimentary rock unit (Kmxs) is gradational in composition betwecn metavolcanic unil (Kmv) and metasedimentary unit (Kms) and contains 50 to 95 percent metasedimentary rock. Typicalty, the predominantly metasedimentary unit consists of dark-gray, scaly argillite, with lenses and layers of green metatuff. Less commonly, it consists of thinly interlaminated green and gray phyllite. The unit locally contains blocks of marble, chcrk, and graywacke.

The cataclasite unit (Kmxu) consists of microbreccia and cataclasite with an inferred protolith of McHugh Complex rocks.

The undifferentiated McHugh Complex (Kmu) contains any of the previous five rock types in proportions that individual units could not be distinguished at map scale. The undifferentiated unit typically consists of intermixed dark-gray, very fine grained argillite, gray-green metatuff, and gray and green phyllite, and it locally contains exotic blocks of graywacke, marble, phyllite, chert, and metadioritc. Additional rock associations in the undifferentialed McHugh Complex unit, too small to show at map scale, include sequences of chert and argillite, assumed to be part of the McHugh Complex because of their lithology and structural position. These sequences consist of dark-gray argillite, silty argillite, contorted slate, and thin-to very thin bedded shale which typically contains interbeds of laminated lightgray chert. These rocks locally contain zones of cataclastic rock.

\section{Alteration and Metamorphism}

The McHugh Complex in the Nelchina-Kings Mountain area is typically metamorphosed to lower or subgreenschist facies assemblages. Metamorpbic 
minerals commonly include quartz, albite, chlorite, epidote, prehnite, pumpellyite, white mica, actinolite, calcite, magnetite, and sphene. Late-stage veins arc composed of quartz and calcite \pm prehnite.

Regionally in the Chugach Mountains, the matrix of the McHugh Complex melange is most commonly metamorphosed in the prehnite-pumpellyite facies, although blocks and belts of blueschist and greenschist occur locally in the Valdez Quadrangle (Clark, 1973; Winkler and others, 1981b). In the Nelchina-Kings Mountain region, the occurrence of apparent relict pumpellyite and the structural fabric observations discussed in the scction on structure suggest that the lower greenschist facies metamorphism was superimposed upon the prehnitepumpellyite metamorphism (Decker, in Burns and others, 1983; Little, 1988).

\section{Age and Correlation}

The age of the McHugh Complex was originally designated as Late Jurassic and(or) Cretaceous (Clark, 1973). In actuality, formation of the McHugh Complex may have spanned most of Jurassic and Cretaceous time. The McHugh Complex contains blocks of fossilifcrous rocks that range in age from Mississippian to Early Cretaceous (Albian) (for example, Winkler and others, 1981b; Nelson and others, 1986), and fossils found in the matrix material range in age from Triassic to Early Cretaceous (Blome and others, written commun., 1989). The youngest exotic blocks incorporated in the mclange arc Albian, and therefore the age of at least part of the McHugh Complex can be no older than Albian. However, Winkler and others (1981b) found that the McHugh Complex in the Valdez Quadrangle is coroposed of northern, middle, and southern bolts which yield fossils of different ages. The oldest belt crops out discontinuously on the north and contains chert with Late Triassic to Early Jurassic radiolarian faunas. The central and southern belts yiclded chert with Late Jurassic to Early Cretaceous, and midCretaceous radiolarian faunas respectively (Winkler and others, 1981b). Tonalite-trondhjemite plutons, which intrude the McHugh Complex in the Auchorage C-5 Quadrangle, have been dated at 110 to $135 \mathrm{Ma}$ (Pavlis, 1982b, 1983; Pavlis and others, 1988). Therefore, deposition of at least part of the McHugh Complex would have occurred by Cretaceous time, prior to the time of the tonalitetrondhjemite intrusion.

\section{Interpretation and Deformation}

The metasedimentary rocks of the McHugh Complex probably were deposited in a marine continental margin setting. Argillaceous material most likely represents hemipelagic slope deposits; graywacke and conglomerate probably represent submarine canyon and base of slope deposits. The common occurrence of diorite as clasts and exotic blocks in the McHugh Complex suggests derivation from nearby contizental erust or island arc. The presence of ocean-floor lithologies, including chert, metabasalt, limestone, and uliramafic rock, and the presence of blueschist facies clasts and blocks within the melange suggest deposition of the $\mathrm{McHugh}$ Complex in a subduction zone setting.

The first dcformation to affect the $\mathrm{McHugh}$ Complex produced a ductilc, chaotic fabric, and most likely was associated with submarine slumping and sliding, but may in part be due to tectoric deformation of unlithified strata during subduction. Subsequent deformation parallels closely the deformation of the Valdez Group and is discussed in the Structural Geology section.

\section{VALDEZ GROUP}

The Valdez Group was originally named the "Valdes series" by Schrader $(1899,1900)$ for rhythmically interbedded graywacke and slate in the Port Valdez area. The name Valdez Group was applied to similar rocks in the Anchorage Quadrangle by Clark (1972a). As now defined, the Valdez Group includes rocks from the southwestern end of the Kenai Peninsula to the Canadian border (Tysdal and Plafker, 1978). In the Nelchina-Kings Mountain area, the Valdez Group contains predominantly lower-greenschist-facies metagraywacke, argillitc, phyllitc, and minor greenstone and conglomerate. These rocks are contiguous with less metamorphosed counterparts along the Kenai Peninsula and in the type area at Port Valdez.

The inboard (northern) contact of the Vaidez Group is the Eagle River thrust. This fault is a regionally shallow, north-dipping structure along which rock of the Valdez Group were thrust beneath the McHugh Complex. The Eagle River thrust was probably active during latest Cretaceous time and was later strongly modificd by Tertiary age deformation. The fault has been locally rotated to near vertical, and has been cut by numerous highangle faults. Wherc metamorphic gradients extend across the fault and similar rock types occur on opposite sides, the distinction between the Valdez Group and the McHugh Complex is not clear. The southern boundary of the Valdez Group (the Contact Faut) does not occur in the Nelchina-Kings Mountain area. 


\section{Petrology and Lithology}

The Valdez Group is highly deformed and characterized by a penetrative, phyllitic cleavage. In the Nelchina-Kings Mountain area, the Valdez Group is a very thick sequence of phyllite, argillie, and thin- to thick-bedded metagraywacke, with minor amounts of gray-green metatuff and stretchedpcbble conglomerate. In this area, volcanic rocks are most abundant in the northern portions of the Valdez Group, and argillite and graywacke are largely metamorphosed to phyllite.

The Valdez Group was subdivided into three map units in the Anchorage C-5 Quadrangle. These units include: (1) black phyllitc, (2) graywacke and argillite, and (3) a conglomeratic graywacke. Farther to the east, thesc units cannot be distinguished as mappable units, due in part to an increased metamorphic grade in that region. Locally, however, protoliths similar to those in the Anchorage C-5 Quadrangle can be recognized. Metatuff and tuffaceous metaconglomerate occur within the Valdez Group in the Anchorage C-4 Quadrangle ncar the head of Coal Creek and were mapped separatcly (unit Kvt).

The black pbyllite unit (Kvp) consists of higbly deformed black phyllite interlayered with $<30$ percent very fine grained, silly metagraywacke. The black phyllite unit is delineated only in the Anchorage C-5 Quadrangle, where the character of the dcformational fabric varies along strike from a slaty cleavage in lower Friday Creck to a phyllitic cleavage at the castern end of the quadrangle.

The graywacke and argillite unit (Kvg) consists of interbedded graywacke and argillite in which the sandstone to shale ratio is at least $1: 1$. Lithologic layering varies from thin $(<1 \mathrm{~cm})$ laminations to large scale interbedding ( $>100 \mathrm{~m}$ ) of predominantly sandstone or predominanlly shale. The metagraywackes are locally coarse grained and conglomeratic. Argillite is indistinguishable from similar rocks of the black phyllite unit. The graywacke and argillite unit is delineated only in the Anchorage C-5 Quadrangle, where it forms the structurally lowest levels of the area.

The conglomeratic graywacke unit (Kvc) consists of massive units of foliated, coarse-grained metagraywacke in which large mud chips are interspersed. In these highly deformed rocks, mud chips now form wafers along foliation surfaces. The conglomeratic graywacke unit is delineated only in the Anchorage C-5 Quadrangle, where two bands of massive conglomeratic graywacke mark the transition from structurally higher, shaly rocks (Kvp) to structurally lower, sandier lithologies (Kvs).
Undifferentiated metasedimentary rocks (Kvs) of the Valdez Group occur east of the Anchorage C-5 Quadrangle and consist predominantly of gray phyllite, argillite, and thin- to thick-bedded metagraywacke. In this region, the Valdez Group is bighly deformed and characterized by a continuous phyllitic cleavage, $S_{1}$, and a younger crenulation cleavage, $S_{2}$ (discussed further in Structural Geology).

The metatuff and tuffacious metaconglomerate unit (Kvt) occurs in the Anchorage C-4 Quadrangle, where it forms two relatively persistent marker horizons. The metatuff commonly is gray-green, moderately well foliated and contains abundant lithic fragments and locally common mud chips. The tuffaceous metaconglomerate consists of stretched pebbles and cobbles in a sandy tuffaceous matrix. Granitic clasts, limestone clasts, and mudstone ripups are recognizable.

\section{Alteration and Metamorphism}

Metasedimentary rocks of the Valdez Group in the Nelchina-Kings Mountain area are moderately to completcly recrystallized. Detrital quartz, feldspar, mica, and rock fragments are best recognized farthest to the west, in the Anchorage C-S Quadrangle. In the Anchorage C-2, C-3, and C-4 Quadrangles, a typical chlorite-zone greenschistfacics assemblage of albite, very fine grained whitc mica, chlorite, calcite, quartz, and sphene occur in the metasedimentary rocks. Actinolite, chlorite, albite, calcite, quartz, and epidote group minerals are typical minerals in the metavolcanic rocks.

\section{Age and Correlation}

Very sparse marine megafossit collections from the Valdez Group on the Kenai Peninsula are all indicative of a Late Cretaceous (Maestrichtian) depositional age (Jones and Clark, 1973). K-Ar ages on the Valdez Group in the Valdez Quadrangle include one whole-rock age of $53.5 \pm 1.6 \mathrm{Ma}$ on a metatuff, and a white mica age of $51.6 \pm 1.5 \mathrm{Ma}$ on a post-metamorphic granitic stock (Winkler and others, 1981b). In the Anchorage C-3 Ouadrangle, biotite which formed in a hornfels zone around a relsitic intrusion ( $\mathrm{Ti}$ ) yielded a $\mathrm{K}-\mathrm{Ar}$ age of $52.1 \mathrm{Ma}$. These ages suggest that metamorphism of the Valdez Group and intrusion of felsites occurred soon after deposition.

\section{Interpretation and Deformation}

The Valdez Group was deposited as part of a large trench-fill system extending from Chatham 
Strait in southeastern Alaska to Sanak Island near the end of the Alaska Peninsula (Moore, 1973; Nilsen and Zuffa, 1982). The graywackes are typical turbidites. Evidence in support of this conclusion was documented from the less metamorphosed rocks of the Valdez Group elsewhere in the Chugach Mountains and on the Kenai Peninsula (Budnik, 1974; Nilsen and Zuffa, 1982). In the Nelchina-Kings Mountain area, relict interbedded sandstone and shale, flattened but still recognizable mud-chip ripups, and rare graded beds and fiute marks are consistent with the marine turbidite interpretation.

Subduction-related imbricate thrust faulting that was in part contemporaneous with deposition was most likely responsible for the first deformational event to affect the Valdez Group. The second, regionally more extensive, deformation occurred in early Eocene time, about $55 \mathrm{Ma}$, and probably is related to emplacement of the structurally underlying Orca Group in the Prince William Sound area. The latest Cretaceous deposition of the Valdez Group and its subduction, low-grade metamorphism, and penetrative deformation in latest Cretaceous to earliest Tertiary time was quickly followed by subaerial exposure and erosional beveling of those metamorphic rocks; they could thus be a source terrain for, and locally, a depositional basement for the Chickaloon Formation. This orogenic event affecting the Valde'z Group must have occurred within a short interval of time (probably less than 5 m.y.) vear the Cretaceous-Tertiary boundary (see Structural Geology section).

\section{DESCRIPTIVE GEOLOGY OF ROCKS COMMON TO BOTH TERRANES}

The oldest rocks common to both the Peninsular and the Chugach terranes belong to a plutonic suite of diorite, tonalite, and trondhjemite of probable Early Cretaceous age (Pavlis, 1982b; 1983; Pavlis and others, 1988). Tertiary rocks common to both terranes include sedimentary rocks of the Chickaloon Formation, hypabyssal dikes of dominantly andesitic and dacitic composition, and coarse-grained basaltic and minor lamprophyric dikes.

\section{CRETACEOUS SYSTEM PLUTONIC ROCKS}

\section{TONALITE-DIORITE-TRONDHJEMITE}

A series of small stocks, sills, and dikes composed dominantly of a distinctive leucotonalite/trondhjemite with minor diorite is exposed in a narrow belt along the Border Ranges fault system in the western part of the mapped area from the Knik River to Ninemile Creek (sheet 1). These plutons bave been the subject of considerable investigation (for examplc, Pavlis, 1982a,b, 1983; Monteverde, 1984; Pavlis and others, 1988) and yield Early Cretaceous K-Ar ages ranging from 135 to $110 \mathrm{Ma}$ (Pavlis, 1982b, 1983; Winkler, personal commun.). In the eastern part of the mapped arca (Anchorage C-1 and C-2 Quadrangles), dikes of trondhjemite up to $1.5 \mathrm{~km}$ wide are abundant in the mixed metamorphic and gabbroic rocks ( $\mathrm{Mz}$ Pzmp unit; sheet 2) of the Peninsular terranc. A K-Ar date from a dike in the eastern part of the mapped area yields an age of $145 \mathrm{Ma}$, or Early Jurassic (table 5). These dikes have not been studied in detail; more is known about the dikes in the western part of the mapped area. Because the mineralogy, K-Ar ages, and level of knowledge differ between trondhjemites in the western and eastern portions of the belt, they are discussed separately.

\section{Dikes in Eastern Part of Map Area}

Troudhjemite dikes in the eastern part of the mapped area weather white and typically bave sharp contacts, crosscutting the country rock. The trondhjemite is generally composed of medium- to coarse-grained plagioclase (60 to 75 percent) and quartz ( 25 to 40 percent), with $<10$ percent hornblende, chlorite and opaque minerals. Trondhjemite is commonly extensively altered, and contains minor quartz-sericite veins, chlorite, muscovite, and contains abundant, fine-grained white mica which replaces plagioclase. Minor amounts of coarse-grained muscovite are present in chlorite veios, and in places grossularitic garnet is present. The trondhjeraite dikes are variably deformed but typically not as deformed as the surrounding metamorphic and gabbroic rocks.

\section{Plutons in Western Part of Map Area}

The bulk of the Early Cretaceous-Late Jurassic(?) intrusive rocks in the western part of the map area are confined to tive stocks with areal exposures of 2 to $12 \mathrm{~km}^{2}$. The rocks clearly intrude the foliated metamorphic rocks along the Border Ranges Fault System, the mafic/ultramalic complexes, and locally, the McHugh Complex. The rocks are weakly foliated locally, indicating some post-eroplacement deformation. Lithologically, the plutons range from tonalite to trondhjemite, although leuco-tonalite with bronze (altered) biotite is characteristic. 
Table 5. K-Ar and U-Pb ages from Cretaceous tonalite and trondhjemite plutonic rocks of the northcentral Chugach Mountains

Analytical work for this study done under the direction of D.L. Turner, University of Alaska Geophysical Institute, Fairbanks, Alaska. Rock types given as in prcvious publications. Abbrevialions include: trond-trondhjemite; bio-biotite; mus-muscovile; hb - hornblende; dio - diorite; - no datal

\begin{tabular}{|c|c|c|c|c|c|c|c|}
\hline $\begin{array}{c}\text { Samplc } \\
\text { no. }\end{array}$ & Unit & Rock & $\begin{array}{c}\text { Mineral } \\
\text { dated }\end{array}$ & $\begin{array}{l}\text { Age } \\
\text { (m.y.) }\end{array}$ & $\begin{array}{l}\% \mathrm{~K}_{2} \mathrm{O} \\
\text { average }\end{array}$ & Quadrangle & Reforence \\
\hline 81JD867a & $K_{1}$ & Trond & Biotite & $145.0 \pm 4.4$ & 1.55 & $\mathrm{C}_{-2}$ & This sludy \\
\hline \multirow[t]{2}{*}{$82 A R M 21$} & $K_{t}$ & Bio mus trond & Biotitc & $136.2 \pm 2.2$ & 8.52 & $D-6$ & Winkler (1989) \\
\hline & & & Muscovite & $142.5 \pm 4.1$ & 10.68 & & mineral pair \\
\hline Pavitis C & $\mathbf{K t}$ & Iib dio & IIornblende & $135 \pm 6$ & - & C.5 & Pavlis (1983) \\
\hline \multirow[t]{2}{*}{ Pavlis II } & KI & Itb bio Irond & Hornblende & $126 \pm$ & - & C-5 & Pavlis (1983) \\
\hline & & & Biotite & $116 \pm$ & - & & mincrat pair \\
\hline $81 \wedge W k 44 b$ & $\mathrm{Kt}$ & Trond & Muscovitc & $110 \pm 3$ & 8.86 & $\mathrm{C}-4$ & Winkler (1989) \\
\hline 79AHI62 (AK341) & $K \mathfrak{t}$ & 'rrond & Zircon & $103 \pm$ & - & C-5 & Winkler (unpub. dals) \\
\hline $81 P c 125$ & $\mathbf{K t}$ & Trond & $\begin{array}{l}\text { White mica } \\
+ \text { chloritc }\end{array}$ & $36.8 \pm 1.8$ & 0.688 & & This study \\
\hline
\end{tabular}

The intrusions are multi-staged, and range from mafic to silicic in composition. These variations probably reflect magmatic differentiation rather than discinct magmatic phases. The oldest (most mafic) igneous rocks are bornblende diorites and tonalites that occur largely as cognate xenoliths and as massive igneous rocks at scattered localities along the plutonic margins. These mafic phases probably represent early crystallization products of a leucotonalitic magma, as they are characteristically coarsegrained along intrusive contacts. These mafic to intermediate plutonic rocks are, in turn, intruded by the leuco-tonalite, the main plutonic phase of the igneous complcx. The leuco-tonalite typically contains bronze biotite, but the rocks range from relativcly dark hornblende-biotite tonalite to biotite trondhjemite. The compositional variations within the main plutonic mass are gradational. These variations may represent differentiation in a magma chamber; however, injection of distinct magmatic pulscs commonly forms gradational contacts. Finally, the youngest plutonic phase within the complex is a series of trondhjemite dikes, which range from thin, 1- to 2 -cm-lhick stringers to massive, 10- to 20-m-thick dikes. Because the leucocratic dikes are restricted to the plutonic complexes and are most abundant near the cores of large plutons, they are presumed to be late differentiates of the main plutonic suite.

The plutonic rocks show considerable variation in mineralogy because of primary composition and hydrothermal alteration. In the early mafic phase of the plutons, hornblende is the only $\mathrm{Fe}-\mathrm{Mg}$ mincral phase and forms up to 50 percent of the rock. The remainder of the rock is composed of plagioclase and
5 to 10 percent quartz, In the main plutonic phase, plagioclasc ( $n_{5}$ to $A_{30}$ ) and quartz are the dominant igneous minerals, with typical modal percentages of 50 to 65 percent and 25 to 35 percent, respectively, and biotite is the principal mafic phase, with modal percentages of about 10 to 15 percent. In the late trondbjemite dikes, dark minerals are generally absent, although a few trondhjemites contain traces of biotite. In addition, the trondhjemites locally contain up to 5 percent muscovite and(or) garnet. Apatite is a ubiquitous accessory in all of the plutonic phases (Monteverde, 1984).

Hydrothermal alteration has variably affected the primary igneous mineralogies of all the Cretaceous plutons, and includes both an alteration that permeated the rock and an alteration that formed younger zeolite veins. Plagioclase is variably saussuritized or sericitized, although altered cores are commonly surrounded by a clear rim of metamorphic(?) albite, Biotite is generally converted to brown chloritc intergrown with radiating interstitial prehnite; this type of alteration gives rise to the characteristic bronze appearance of biotite in hand sample. Amphiboles are not conspicuously altered, altbough many are actually actinolite in composition, suggesting these hornblende grains were completely converted to actinolite under greenschist facies conditions (Monteverde, 1984).

The rocks show considerable textural variation related to both the amount of strain and degree of alteration. The least altered rocks typically show little, if any, evidence of deformation and are characterized by hypidiomorphic granular textures. 
Near plutonic margins and laults, the rocks arc conspicuously foliated. The foliation is delined largely by aligned biotite and elongated quartz. On a microscopic scale, this foliation is generally associated with alteration of biotite to chlorite + prebnite, and its character as a deformalional fabric is clearly indicated by: (1) kinking of biotite, (2) dyaamic recrystallization of quartz to produce seriate textures, and (3) kinking and grain breakagc in plagioclase.

\section{Composition of Both Eastern and Western Trondhjemites}

Seven trondhjemite samples were analyzed for major oxide composition (table 6). Harker diagrams based on additional analyses of trondhjemile and related tonalite from plutons in the Anchorage C-4 and C-5 Quadrangles are presented in Pavlis and otbers (1988) and are not reproduced here. All of the anaiyzed trondhjemites contained $<15$ weight percent $\mathrm{Al}_{2} \mathrm{O}_{3}$ and therefore correspond with the low-aluminum trondhjemite field of Barker and others (1976). Two of the analyzed trondhjemites (samples 81Bu135, 81Bu129, table 6) intrude preJurassic metamorphic rocks and Jurassic gabbroic rocks; the other trondhjeraites shown in table 6 are from plutons in the Anchorage C-4 and C-5 Quadrangles. None were compositionally distinct from the trondhjemites presented in Pavlis and others (1988).

\section{Age, Correlation, and Interpretation}

The compositional and mineralogical data do not constrain the environment in which the trondhjemite rocks formed. The trondhjemite may have resulted from fractionation of mafic magma or quartz dioritic magma, subsolidus alteration of quartz diorite, or from partial melting of metamorphic rocks, such as amphibolite or metagraywacke, or of gabbroic rocks. Pavlis and others (1988) present convincing arguments, based on age dates, for generation of the plutons in the west during underthrusting of the McHugh Complex beneath the Peninsular terrane.

Radiometric ages (table 4 and 5) on these rocks suggest that trondhjemite intrusion may have occurred in the Chugach Mountains during a time spar of at least $20 \mathrm{~m} . y$., from about 110 to $130 \mathrm{Ma}$. The oldest age, from a K-Ar determination on hornblende from a trondhjemite dike in the Anchorage C-2 Quadrangle, was $145 \mathrm{Ma}$ (table 4; fig. 3). Assuming all the ages are roughly accurate, the Jurassic age may either imply an cvent associated with the dcath of the Jurassic arc or be an early part of the near-trench plutons produced during thrusting (as discusscd in Pavlis and others, 1988).

$\mathrm{K}-\mathrm{Ar}$ ages on trondhjemite from the southern Talkectna Mountains to the north of the map arca (fig. 1) arc similar to ages on the Chugach trondhjcmites and range from 125 to $148.5 \mathrm{Ma}$, with a concordant $\mathrm{K}$-Ar age on biotitc (143 $\mathrm{Ma}$ ) and muscovite (146 Ma) (Cseljey and others, 1978). The relationship between the trondhjemites and related rocks of the Talkeetna and Chugach Mountains is not understood, but they may have formed from similar processes.

\section{TERTIARY SYSTEM}

Rocks of Tertiary age in the Nelchina-Kings Mountain region include clastic sediments of the Chickaloon Formation, dikes and hypabyssal plugs, of dacitic to andesitic composition, and mafic dikes. In general, the Chickatoon Formation unconformably overlics rocks of the Peninsular terrane, but the unit also unconformably overlies rocks of the Chugach terrane at one location. The dikes and plugs of dacitic and andesitic rocks are gencrally referred to as felsites; they intrude rocks of both the Chugach terrane and the Peninsular terrave (Winkler and others, 1981b; Silberman and Grantz, 1984; this study).

\section{SEDIMENTARY ROCKS OF THE CHICKALOON FORMATION}

A partial section, $>1 \mathrm{~km}$ thick, of late Paleoceneearly Eocene clastic sedimcntary rocks is exposed along the north flank of the Chugach Mountains. Thesc rocks consist of conglomeratc, sandstone, siltstone, and mudstone of chiefly fluvial origin, and are hcre correlated wich the Chickaloon Formation in the Mataruska Valley. Along the northern edge of the Chugach-St. Elias Mountains, exposures of Paleogene sedimentary rocks are uncommon. The only known outcrops of such rocks are located in and near this study area.

The present distribution of Chickaloon Formation in the Nelchina-Kings Mountain region is structurally controlled. Chickaloon Formation is preserved (1) west of the Matanuska Glacicr in a downdropped fault block, bounded on the north by the Lower Jurassic Takkeetna Formation of the Peninsular terrane, and on the south by the Upper Cretaceous Valdez Group of the Chugach terranes; (2) farther north in the Peninsular terrane, where the southern, north-dipping limb of the Matanuska 
Table 6. Major-axide analyses and CIPW noms of trondhiemite (trond) from the northcentral Chugach Mountains [Aralyses performed at the Alaska Division of Gcological and Geophysical Surveys by N.C. Veach and Kate Bull. $\mathrm{PeO}^{*}$ and $\mathrm{Fe}_{2} \mathrm{O}_{3} 3^{*}$, total molecular $\left.\mathrm{Fc}_{c} ; \mathrm{A}_{1}\left(\mathrm{Na}_{2} \mathrm{O}+\mathrm{K}_{2} \mathrm{O}\right) / \mathrm{Na}_{2} \mathrm{O}+\mathrm{K}_{2} \mathrm{O}+\mathrm{FeO}^{*}+\mathrm{MgO}\right) ; \quad \mathrm{F}, \quad \mathrm{FeO}^{*} /\left(\mathrm{Na}_{2} \mathrm{O}+\mathrm{K}_{2} \mathrm{O}+\mathrm{FeO}^{*}+\mathrm{MgO}_{3}\right) \mathrm{M}$, $\mathrm{MgO} /\left(\mathrm{Na}_{2} \mathrm{O}+\mathrm{K}_{2} \mathrm{O}+\mathrm{PeO}^{*}+\mathrm{MgO}\right) ;$-, not applicable; norm An, an/(an+ab+or); $\mathrm{Ab}$, ab/(an+ab+or); Or, or/(an+ab+or)I

\begin{tabular}{|c|c|c|c|c|c|c|}
\hline Rock type & trond & trond & trond & trond & trond & trand \\
\hline Quadrangle & $C-4$ & $C-4$ & $C-4$ & C-1 & $C_{1}$ & $C-4$ \\
\hline Ficld no & $83 \mathrm{Pe} 7$ & $83 \mathrm{~F}_{\pi} 39 \mathrm{a}$ & $83 F n 12$ & $81 B u 135^{a}$ & $81 B u 129^{2}$ & $83 F n 40 b$ \\
\hline
\end{tabular}

\begin{tabular}{|c|c|c|c|c|c|c|c|}
\hline \multicolumn{8}{|c|}{ Chemical analyses (wcight percent) } \\
\hline $\mathrm{SiO}_{2}$ & 71.87 & 73.51 & 73.90 & 74.55 & 74.95 & 76.12 & 78.36 \\
\hline $\mathrm{Al}_{2} \mathrm{O}_{3}$ & 13.91 & 13.86 & 14.23 & 13.32 & 11.49 & 14.58 & 12.22 \\
\hline $\mathrm{IcO}$ & -- & - & - & 0.54 & 0.92 & - & - \\
\hline $\mathrm{Fe}_{2} \mathrm{O}_{3}$ & - & -- & - & 0.28 & 0.44 & -- & - \\
\hline $\mathrm{MgO}$ & 1.36 & 0.88 & 1.13 & 0.49 & 0.38 & 0.33 & 0.48 \\
\hline $\mathrm{CaO}$ & 4.25 & 2.43 & 1.53 & 1.44 & 2.36 & 0.63 & 2.02 \\
\hline $\mathrm{Na}_{2} \mathrm{O}$ & 3.26 & 5.55 & 4.92 & 5.30 & 6.09 & 5.62 & 4.78 \\
\hline $\mathrm{K}_{2} \mathrm{O}$ & 0.12 & 0.27 & 1.10 & 0.99 & 0.31 & 2.37 & 0.60 \\
\hline $\mathrm{TiO}_{2}$ & 0.32 & 0.39 & 0.15 & 0.10 & 0.07 & 0.02 & 0.06 \\
\hline $\mathrm{P}_{2} \mathrm{O}_{5}$ & 0.05 & 0.08 & 0.10 & 0.07 & 0.08 & 0.09 & 0.04 \\
\hline $\mathrm{MnO}$ & 0.08 & 0.02 & 0.05 & 0.04 & 0.06 & 0.06 & 0.02 \\
\hline LOI & 1.16 & 0.66 & 1.22 & 1.24 & 1.89 & 0.56 & 1.00 \\
\hline $\mathrm{Pe}_{2} \mathrm{O}_{3}$ & 4.05 & 2.84 & 1.92 & $=$ & $\ldots$ & 0.47 & 0.84 \\
\hline TOTAL & 100.43 & 100.49 & 100.25 & 98.36 & 99.04 & 100.85 & 100.42 \\
\hline $\mathrm{PcO} * / \mathrm{MgO}$ & 2.67 & 2.90 & 1.53 & 1.62 & 3.46 & 1.28 & 1.57 \\
\hline$A$ & 40.3 & 62.9 & 67.8 & 83.1 & 79.1 & 91.4 & 81.3 \\
\hline F & 43.4 & 27.6 & 19.4 & 10.5 & 16.2 & 4.8 & 11.4 \\
\hline$M$ & 16.2 & 2.5 & 12.7 & 6.5 & 4.7 & 3.8 & 7.3 \\
\hline \multicolumn{8}{|c|}{ CIPW norms (wcight percent) } \\
\hline$q t z$ & 41.0 & 34.0 & 34.8 & 37.1 & 35.1 & 32.7 & 43.6 \\
\hline or & 0.7 & 1.6 & 6.6 & 6.0 & 1.9 & 14.0 & 3.6 \\
\hline$a b$ & 27.8 & 47.1 & 42.0 & 46.2 & 53.0 & 47.4 & 40.7 \\
\hline an & 21.0 & 11.6 & 7.0 & 6.9 & 3.2 & 2.5 & 9.8 \\
\hline dî & - & -- & --- & - & 4.7 & - & - \\
\hline hy & 5.2 & 2.2 & 2.8 & 3.9 & - & 0.8 & 1.2 \\
\hline mit & 2.7 & 1.7 & 0.5 & 0.4 & 0.7 & 0.1 & 一 \\
\hline il & 0.6 & 0.7 & 0.3 & 0.2 & 0.1 & - & - \\
\hline ap & 0.1 & 0.2 & 0.2 & 0.2 & 0.2 & 0.2 & 0.1 \\
\hline cor & 0.8 & 0.2 & 2.4 & 1.1 & - & 1.8 & 0.1 \\
\hline $\mathrm{hm}$ & - & 0.7 & 1.3 & - & - & 0.4 & 0.8 \\
\hline wo & $\cdots$ & - & - & - & 1.2 & - & - \\
\hline Norm An & 42.3 & 19.2 & 12.6 & 11.7 & 5.5 & 4.0 & 18.2 \\
\hline$A B$ & 56.2 & 78.2 & 75.6 & 78.2 & 91.3 & 74.2 & 75.2 \\
\hline Or & 1.4 & 2.7 & 11.8 & 102 & 3.2 & 21.8 & 6.6 \\
\hline
\end{tabular}

\footnotetext{
Analyses 81 Bu135 and 81 Bu129 intrude the pre-Jurassic metamorphic rocks and the gabbroic racks and are similar to the trondhjemite
} yielding of a $\mathrm{K}$-Ar age $145 \mathrm{Ma}$ (table 4).

Valley synclinorium emerges along the Chugach range front; (3) in the Peninsular terrane in a narrow faule-slice between Glacier and Ninemile Creeks; and (4) in two locations in the Chugach terrane (hig. 3, sheets 1 and 2). The Chickaloon Formation, in all of these exposures, is folded and faulted due to its involvement in an early Tertiary deformational event (see Structural Geology section).

The type-section Chickaloon Formation in the Matanuska Valley unconformably overlies the Upper Cretaceous Matanuska Formation, with. no more than slight angular discordance along a poorly 
exposed contact (Waring, 1936; Barnes and Payne, 1956; Grantz, 1961b; Barnes, 1962). Along the northernmost edge of the Chugach Mountains, the Chickaloon Formation also overlies the Matanuska Formation disconformably (Little and others, 1986b). Farther south in the Chugach Mountains, the Chickaloon Formation generally overlies the Lower Jurassic Talkeetna Formation with slight to pronounced angular discordance, and locally overlies Jurassic quartz diorite along a low-angle fault contact, probably a faulted nonconformity. In one location in the Anchorage C-1 Quadrangle, just west of the Nelchina Glacier, sedimentary rocks lithologically and stratigraphically similar to the Chickaloon Formation unconformably overlie both the McHugh Complex and Upper Cretaceous Valdez. Group of the Chugach terranc (Iigs. 2 and 3; Pessel and others, 1981). These sedimentary rocks overlie the latest Cretaccous age rocks of the Valdez Group and are intruded by probable Eocene age felsite dikes. Thus, a Paleocene-Eoccne age seems likely.

The upper contact of the Chickaloon Pormation is not exposed in the Chugach Mountains. Eocene and younger sedimentary rocks that overlie the Chickaloon Formation in the Matanuska Valley (Barnes and Payne, 1956; Clardy, 1974) may also have been present in the region of the present Chugach Mountains, but have been stripped away by erosion.

\section{Petrology and Lithology}

The Chickaloon Formation in the northern Chugach Mountains generally consists of wellindurated pebble conglomerate and lesser sandstone interbedded witb subequal amounts of mudstone and minor siltstone. Rhythmic alternation of coarse- and fine-grained beds is characteristic of the formation. Subunits in the formation are characterized by different average proportions and thicknesses of conglomerate beds relative to mudstone beds (sec section on variations below).

Conglomerate, sandstone, and mudstone beds are typically found in several-meter-thick, fining-upward, rhythmic sequences. Very thick beds of cobble or pebble conglomerate at the base of a sequence commonly grade vertically into granular conglomerate or sandstone. These beds are in turn abruptly to gradationally overlain by a bed of coarseto medium-grained sandstone or by a sequence of beds of fine to coarse sandstone and(or) granular conglomerate. Mudstone or siltstone occurs at the top of a sequence. Conglomerate was probably deposited as longitudinal bars during floods. The general upward fining of conglomerate beds suggests deposition during waning flow associated with progressive emergence of the bars in the wake of a high-water event. Overlying sandy beds were probably deposited during lateral migration and abandonment of shallow river channels that were incised into the emergent gravel bars. Mudstone beds at the top of the sequence are interpreted as overbank sediments deposited in areas rclatively remote from channel axes.

Conglomerate.-Conglomerates are poorly sorted, clast-supported mixtures of subrounded to subangular pebbles with a matrix of subangular coarse sand and granules. Typical maximum clast diameter ranges from 2 to $7 \mathrm{~cm}$. Clasts with maximum diameters in the range of 10 to $15 \mathrm{~cm}$ are common in some parts of the formation, and boulders to $1.5 \mathrm{~m}$ diam occur locally.

Conglomerate beds are generally thick or very thick, ranging between about 0.75 and $2 \mathrm{~m}$ in thickness, but locally units to $5 \mathrm{~m}$ and over $10 \mathrm{~m}$ thick are present. Beds of conglomerate have erosive basal contacts and flat upper contacts. Beds are most commonly massive, but bedding is defuned locally by a crude alignment of elongate clasts or by interbeds of finer grained conglomerate. Bedding includes both horizontal and cross-stratified types. Scour surfaces locally bound lenses, 10 to $30 \mathrm{~cm}$ thick, of coarse-graived sandstone that are surrounded by pebble conglomerate. Molds and casts of fallen tree trunks are common along coarsegrained, sandy bases of conglomerate beds.

The average grain size in a conglomerate lens varies verticaliy and latcrally. Conglomerate beds are usually normally graded and may grade upward from coarse pebble or cobble conglomerate at the base to fine pebble or granular conglomerate. A thin layer or erosionaliy truncated wedge of reversegraded sandstone and conglomerate is common along the base of beds. In general, the average grain size in a given bed decreases systematically from a maximum in the thickest part of a lens to a minimum (commonly sandstone) at the feather edges of a lenticular channel.

Sandstone.-Sandstone in the Chickaloon Formation is fine to coarse grained and consists of moderately sorted, subangular, chiefly lithic grains. Sandstone is brown to greenisb-gray and well indurated. Greenish coloration is caused by pre- and post-depositional alteration of volcanic lithic fragments to chlorite and by past-depositional growth of chlorite cement. Compaction and 
deformation of lithic grains and diagenetic growth of chlorite \pm laumontite $(\mathrm{Ca}-\mathrm{A} l$ zeolite $) \pm$ clay \pm calcite have resulted in low porosity. This diagenetic alteration (or burial metamorphism), mean vitrinite reflectance values in the range of 0.5 to 0.9 , and apatite Iission track data (Listle, 1988; Little and Nacser, 1989) suggest that the Chickaloon Formation was once buried under a significant thickness of younger sediments.

Sandstone beds are generally $<1 \mathrm{~m}$ thick and beds 10 to $70 \mathrm{~cm}$ thick are typical. Beds arc generally lenticular in shape and are massive or parallel-laminated, or cross-laminated into tabular or trough-shaped sets. Low angle cross-strata of sandstone commonly lap onto or drape the margins of channels incised into conglomerate. These internally cross- or parallel-laminated bedforms are bounded above and below by sharp bedding surfaces and thicken and coarsen laterally 10 a maximum along the floor of the channel, suggesting that they formed by lateral accretion of the channel margin. Many sandstone beds are normally graded, from coarse-grained or granular sandstone near the base to fine- or medium-grained sandstone at the top, but this pattern often is complicated by thin to thick interbeds of coarse sandstone or fine pebble conglomerate.

Mudstone-Mudstone in the Chickaloon Formation is a medium-brown to black, generally non-fissile mixture of clay, silt, and fine-grained carbonaceous material. Mudstone beds are approximately tabular in shape and range in thickness from $5 \mathrm{~cm}$ to several tens of meters; beds 0.5 to $2 \mathrm{~m}$ thick are most common. Very thick (>1 m) mudstone beds commonly contain thin ( $<10$ $\mathrm{cm}$ ) interbeds of siltstone or fine sandstonc, leaf impressions, and fragments of petrified wood.

\section{Clast Types and Sandstone Petrography}

Conglomerates in the Chickaloon Formation are polymictic and contain clasts of underlying Peninsular terrane rocks as well as clasts of rocks from the Cbugach terrane. Between the Matanuska Glacier and Ninemile Creek (fig. 3), conglomerate clasts consist predominantly of recrystallized impure chert and siliceous argillite with subordinate amounts of pyroclastic and porphyritic andesitic volcanic rocks identical to rocks in the Talkeetna Formation. Clasts of massive and foliated plutonic rock are somewhat less common and consist of gabbronorite, hornblende gabbro, diorite, quartz diorite, and tonalite identical to the plutonic rocks of the
Peninsular terrane. Clasts of metamorphic rocks similar to those in the Peuinsular terrane, such as ampbibolite, are rare. Red radiolarian chert, "graywacke" sandstone and siltstone, low-grade phyllite, and veia quartz, are minor but ubiquitous constituents, and are probably derived from the Chugach terrane. Some chert clasts contain poorly preserved radiolarian assemblages indicative of a Karnian (Late Triassic) age and otbers of Mesozoic (probably Jurassic and Cretaceous) age (C. Blome, as quoted in Little, 1988). These ages are comparable to those of chert blocks from the McHugh Complex in the Valdez Quadrangle (Winkler and others, 1981b; Nelson and others, 1986) and south of Anchorage (Karl and others, 1979), which also include radiolarian assemblages of Late Triassic and Early Cretaceous age.

Conglomerates deposited unconformably on the Chugach terrane west of the Nelchina Glacier (fig. 3), contain the same clast types as those described above but are richer in low-grade mctamorphic clasts such as recrystallized chert and siliceous argillite, aphyric greenstone and metatuff, and green and black low-grade phyllitc. Distinctive gray and mauve-colored bypabyssal or volcanic felsite clasts are locally quite abundant. The source of these felsitc clasts is uncertain, but they may derive from supracrustal parts of the Palcogene Sanak-Baranof magmatic belt (Hudson and Plafker, 1982) in the Chugach terrane to the south, an early phase of the Tertiary felsite plutonism in the area, or Jurassic felsic rocks of the Peninsular terrane.

Sandstones in the Chickaloon Formation are lithic arenites. Impure chert (recrystallized), argillite, "graywacke," phyllite, and other low-grade metasedimentary fragments combined are about three times as common as andesilic (and less commonly basaltic) volcanic and metavolcanic lithics. Monocrystalline plagioclase and quartz are generally minor constituents, but cataclastically deformed, altered grains of plagioclase (polycrystalline) are locally a major component of the rock and were probably derived from dioritic or gabbroic rocks of the Peninsular terrane. Lithic fragments of diorite, microdiorite, and conalite are minor but widespread constituents, as are coarsely polycrystalline quartz grains of probable metamorphic origin; potassiumfeldspar is absent. Trace detrital constituents include chlorite, epidote, muscovite, carbonate, opaque oxide, homblende, biotite, clinopyroxene, prehnite, pumpelyyite, and, near the Nelchina Glacier, blue sodic amphibole. Uncommon white-weathering (laumontitic) sandstone beds contain a component of furst-cycle cuffaceous material, such as broken 
crystals of volcanic quartz, sanidine, plagioclase, and devitrified fragments of volcanic glass.

\section{Vertical and Lateral Variations}

A typical vertical section of the Chickaloon Formation between Glacier and Gravel Creeks (fig. 3, sheet 2) is fine grained and mud-rich at the base, coarse grained and conglomeratic in the middle parth and fine grained near the exposed top. Near the base of the formation, the Chickaloon consists chiefly of black, carbonaccous mudstone with minor thin beds of orange-weathering marl (probably freshwater limestone). Coal is present locally and pelrified wood is common. With the exception of a several-meter-thick basal conglomerate bed that unconformably overlies the Talkeetna Formation, coarse clastic beds are uncommon in the basal part of the formation. Moreover, the conglomerate beds are seldom more coarse grained than a granular conglomerate or thicker than $1 \mathrm{~m}$. The ratio of mudstone to conglomerate + sandstone is about 10:1. This basal mud-dominated unit (10 $100 \mathrm{~m}$ thick) grades upward into a unit about $150 \mathrm{~m}$ thick which is characterized by a mudstone to conglomerate + sandstone ratio of about $1: 1$. Mudstone in this unit is generally brownish ratber than dark gray or black. Above this well-bedded unit is a massive coarse-grained conglomcrate unit that locally exceeds $400 \mathrm{~m}$ in thickness. Mudstone and sandstone beds arc uncommon in this unit. A discontinuous marker bed of coarse, hematitecemented conglomerate to $20 \mathrm{~m}$ thick commonly occurs near the top of the unit. Overlying this conglomerate-dominated unit is another conglomeratic unit, $>300 \mathrm{~m}$ thick, distinguished by its tabular-bedded appearance. Fining-upward sequences of sandstone and mudstone, generally $<60 \mathrm{~cm}$ thick, are present betwecn 1- to 4 m-thick conglomerate beds. Upsection, conglomerate beds in this unit are systematically thinner and mudstone beds are thicker, so that the ratio of mudstone to conglomerate + sandstone ranges from about $1: 8$ near the base to 1:3 near the top.

The Chickaloon Formation is characterized by rapid lateral facics changes and general lenticularity of units, and by abrupt lateral variations in its thickness and in the lithology of its depositional basement. Two facies end members are: (1) a conglomerate-dominated facics, in which conglomerate units are very thick (to $10 \mathrm{~m}$ or more) and coarse grained (maximum clast diamcter commonly 10 to $15 \mathrm{~cm}$ or more) and mudstone beds are thin $(<0.5 \mathrm{~m})$ or absent; and (2) a mud- dominated facies, in which conglomerate beds are thin (about $1 \mathrm{~m}$ ) and relatively fine grained $(<2 \mathrm{~cm})$ and mudstone beds are very thick ( $1010 \mathrm{~m}$ or morc).

Between the Matanuska Glacier and Gravel Creek (frg. 3), over a distance of about $2 \mathrm{~km}$ northward from the southern faull contact of the formation with the Chugach terrane, the abovedescribed stratigraphic sequence has marked lateral variation. This lateral variation may be summarized as follows: (1) the basal mud-dominated unit and(or) the well-bedded unit above it abruptly thickens, (2) the massive coarse conglomcrate unit near the middle of the formation pinches out, and (3) the tabularmbedded unit above it becomes distinctly thinner bedded and more mudstone-rich. In the same direction, the depositional basement for the formation changes from (1) Jurassic quartz diorite along the southern edge of cxposure to (2) Talkeetna Formation along the north Mlank of the range to (3) Matanuska Formation at the edge of the Matanuska Valley.

\section{Age and Correlation}

Chickaloon Formation sedimentary rocks contain abundant plant fossils of late Paleocene \pm early Eocene age that are identical to those found in the type area of the Chickaloon Formation in the Wishbone Hill coal district of the Matanuska Valley (Wolfe and others, 1966; Triplchorn and others, 1984; Wolfe, as quoted in Liftle, 1988). A middle to late Eocene minimum age for the Chickaloon Formation is indicated by zircon fission-lrack minimum ages of 43 to $48 \mathrm{Ma}$ for felsite dikes that intrude the Chickaloon Formation (Little and Naeser, 1989; sce Hypabyssal Rocks section). Such dikes commonly intrude the Chickaloon Formation, both in the Matanuska Valley and in the Chugach Mountains.

\section{Interpretation}

Clastic detritus in Chickaloon Formation in the Chugach Mountains was derived from both Peninsular and Chugach terranes (Little, 1988). Conglomerate and sandstone compositions indicate that clastic dctritus was partially derived from erosion of the mafic to intcrmediate plutonic and andesitic volcanic rocks of the Peninsular terrane which commonly underlie the formation. The predominance of chemically and mechanically unstable clasts of weakly metamorphosed chert/argillite (which yield Mesozoic fossils), graywacke, and (locally) greenstone that are lithologically indistinguishable 
from low-grade rocks of the McHugh Complex, as well as clasts of graywacke and phyllite similar to Valdez Group metasedimentary rocks, indicate that bolk units of the Chugach terrane were important sediment sources also. A southern source for Chickaloon Formation sediments from. faulted and uplifted rocks of the Chugach terrane is also suggested by lithofacies adjacent to the Border Ranges fault. The lithofacies contains greenstone, metatuff, and phyllite clasts, in addition to typical clasts found in the Chickaloon Formation. North of the Border Ranges fault, the massive conglomerate unit of the Chickaloon Formation contains chert boulders $1.5 \mathrm{~m}$ diam that could have been derived only from adjaccnt rocks of the Chugach terrane to the south. A trend of northward thinning and fining of conglomerate beds, together with a corresponding incrcase in the thickncss and proportion of mudstone beds and a predominance of northward and westward paleocurrent directions, provides added evidence for northward sediment transport (Little, 1988). This trend indicates a more distal environment to the north. In contrast to its conglomeratic exposures in the Chugach Mountains, Chickaloon Formation in the Matanuska Valiey consists chicfly of mudstone and coal, with subordinate sandstone, and contains only minor fine-grained conglomerate near its base (Barnes and Payne, 1956). Chickaloon Formation sandstones in the Matanuska Valley (Winkler, 1978) are litbic arenites, but these sandstones are more quartzose than ageequivalent sandstones in the Chugach Mountains to the south, contain K-feldspar, and contain a higher ratio of volcanic to total lithic fragments. This lateral difference in Chickaloon sandstone petrography indicates that fluvial sands became compositionally more mature and(or) increasingly diluted by otber volcanic and plutonic source regions to the north.

In the Chugach Mountains, the Cbickaloon Formation is chicfly of fluvial (locally lacustrine) origin (Little, 1988). Large deciduous leaf fossils and petrified wood throughout the formation indicate a terrigenous origin in a humid climate. The abundance of laterally continuous beds of carbonaceous mudstone and siltstone indicate that poorly drained, swampy floodplains were an integral part of the fluvial system. The mudstone-dominated basal unit of the formation was deposited in a forested, swampy environment of low relief, dissected by a meandering(?) system of shallow stream chanels and local lakes. Above the mudstone-dominated unit, the upward thickening and coarsening sequence of conglomerate beds, capped by the thick wedge of coarse-grained, massive conglomerate with almost no interbedded sandstone and mudstone, probably reflects the northward progradation of an alluvial fan system. This fan system flanked a scarp (or scarps) of the ancestral Border Ranges fault system, which underwent a component of south-side-up displacement during deposition of the Chickaloon Formation. The alluvial system, judging from the coarseness of its bedload and the morphologic complexity of its thin channel sequences, probably consisted of shallow, braided streams. Because the climate was humid and soils were thick and clayey, the streams were supplied with a copious suspended load that was periodically deposited on extensive floodplains peripheral to channel axes. Northward and westward paleocurrent directions in Chickaloon Formation of the Cbugach Mountains (Little, 1988), and regional isopach trends for Cretaceous and Tertiary rocks in Cook Inlet (Kirschner and Lyon, 1973; Boss and others, 1976; Hartman and others, 1972) suggest that alluvial fans flanking the proto-Chugach Mountains werc tributary to a longitudinal drainage system along the present-day Cook Inlet-Matanuska Valley trend.

Like the Upper Cretaceous Matanuska Formation beneath it, the Chickaioon Formation was probably deposited in a complex struetural basin. The late Paleocene to early Eocene age Chickaloon Formation is presently situated between cocval magmatic arc rocks to the north and northwest (Moll and Patton, 1983; Wallace and Engebretson, 1984) and a subduction complex (the Orca Group) to the south (Helwig and Emmet, 1981). Airfall and waterlaid siliccous tuff occurs locally in the Chickaloon Formation, both in the Matanuska Valley (Conwell and others, 1981), and in the Chugach Mountains, suggesting that a distant magmatic arc was active during deposition of the formation. The disconformity between the Matanuska and Chickaloon Formations represents a transition between marine (probably deep marine) and nonmarine depositional systems. The Cook Inlet-Matanuska Valley forearc basin thus appears to have been considerably uplifted, without appreciable folding, during latest Cretaceous to earliest Tertiary time, although the effect could be, in part, eustatic. Along the north flank of the Chugach Mountains, this uplift was accompanied by highangle block-faulting and erosion, as indicated by mapping of pre- 10 syndepositional faults beneath the Chickaloon Formation. South-side-up motion on these faults has resulted in exposures of progressively deeper structural levels of Jurassic and Cretaceous basement overlapped in a southward direction by the 
Chickaloon Formation (Little, 1988). This blockfaulting created a topographically positive arca along the southern margin of the forearc basin.

\section{HYPABYSSAL ROCKS}

Hypabyssal dikes and small plugs of tan-, bulf-, and orange-weathering lcucocratic rock of andesitic, dacitic, and possibly erondhjemitic composition (table 7) intrude rocks of both likc Cliugach and Pcrinsular tersancs in the Valde\% (Winkler and others, 1981b) and Anchorage Quadrangles. Felsitc plutons and dikes are also common to the north of the Chugach Mountains in the Matanuska Valley and northern Talkcetna Motntains, where they intrude Mesozoic and Paleocene sedimentary rocks of lise Peninsular terrane (Grantz, 1960a,b, 1961a,b; Csetjey and others, 1978; Fuchs, 1980; Silberman and Grantz, 1984).

Locally, as in the region between Glacicr and Gravel Creeks (Anchorage C-3 Quadrangle; lig. 3), tabular-shaped felsite plutons clearly intrude the older fault boundary between the Pcninsular and Chugach terranes, indicating that at least some of the felsiles post-date the latest major event of faulting between the two terranes. Thesc plutons are petrographically similar to fclsite plutons intruding other parts of the Peninsular terrane. Howcver, many of the felsites occurring entirely within the Chugach terrane have slightly different petrographic characteristics and older K-Ar ages (see below) than those in the Peninsular terrane. Hence, more than one generation of silicic intrusives may be prescol in the Nelchina-Kings Mountain region.

\section{Peninsular Terrane Felsites}

Felsites in the Peninsular terrane commonly intrude along or across high-angle faults and cataclastic zones and are also present as discordant dikes cutting normal, reverse, and strikc-slip \{aults. Four large, irregular-shaped felsite plutons also intrude Peninsular terrane rocks in and north of the Matanuska Valley. Major-oxide compositions of three felsite intrusives which intrude the Pcninsular terrane support the field observation that the rocks are of andesitic to dacitic composition (table 7). In contrast to the Jurassic plutonic rocks, the felsites show very little brittle or cataclastic deformation, and are generally not cut by large displacement faults. The high-level intrusion of the felsites is intcrpreted to posidate most of the faulting along the north flank of the Chugach Mountains.

Felsites in the Peninsular terrane cypically have a microcrystalline groundmass. A few of the larger felsite intrusions have a finc-grained holocrystalline texture. Some felsites are aphyric, but most contain to 5 percent small (1 $102 \mathrm{~mm}$ ), sublicdral to cuhedral phenocrysts of plagioclase \pm lesser quarlz and small amounts (10 about 3 perecnl) of biotite and(or) hornblende phenocrysts. Although the plagioclase phenocrysts are now commonly albitized, relict oligoclase or andesine is prescrved locally. Obvious zoning is uncommon. The fincr grained quarlz phenocrysts are gencrally clear, lack undulose cxtinction, and show resorbed or relict bela-quarl\% oullines. The groundmass of the felsites commonly contains 70 to 80 percent microlitic, lcss commonly cquant, plagioclase subhedra and 20 to 30 percent interstitial quartz anhedra. Accessory mincrals include opaque oxide (commonly hematile placelets), apatite, eircon, and sphenc. Tracliytoid (llowaligned) plagioclasc microlizes and minor patches of myrmekitic texture are present in some felsitcs.

A relatively large $(1 \mathrm{~km})$ lens-shaped compositc pluton at Kings Mountain (Anctiorage D-4 and D-5 Quadrangles; fig. 3), probably represents a coarser graincd phase of the felsitic intrusives. The Kings Mountain pluton consists largcly of mcdium.grained, hypidiomorphic-granular, hornblende granodiorice. The rock contains about 40 percent anhedral quarr and about 15 percent perthitc. Poikilitic hornblende is an accessory mineral. Minor aunounts of biotice, apatite, zircon, and sphene arc also present (Liclle and others, 1986b).

The felsite intrusions in the Peninsular terrane are pervasivcly altered. Plagioclase phenocrysts are typically albitized or parlly replaced by a molted intergrowth of laumontite (detcrmination by $\mathrm{X}$-ray diffraction). In addition, plagioclase grains are generally clouded by finc-grained calcite, white mica, and opaque dust. Fine-grained granules of epidote are a less common alteration product of plagioclasc. Hornblende and biotite grains are partly 10 completely replaced by clots of chlorite and calcite : white mica. The groundmass is altered by patches of white mica, calcite, and aroorphous-looking seams of amber-colored opaque dust which includes tiny disseminated grains of hematite. This material, much of it an alteration product of pyrite, commonly coats fractures and is responsible for the typical orange-staining of felsites.

\section{Chugach Terrane Felsites}

Felsites intruding the Chugach terrane are most abundant in the Valdez Group where they occur as sills that intrude the second foliation, $S_{2}$ (see section on structural geology). Locally, the felsites crosscut 
Table 7. Major-oxide analyses and CIPW norms on hypabyssal rocks of the northcentral Chligach Mountains. These felsites intrude the Peninsular lerrane

[Analyses performed at Alaska Division of Geological and Geophysical Surveys by N.C. Veach and Kate Bull. $\mathrm{FeO}^{*}$ and $\mathrm{Fe}_{2} \mathrm{O}_{3}$ ". total molecular $\mathrm{Pe}$; $\mathrm{A}$, $\left(\mathrm{Na}_{2} \mathrm{O}+\mathrm{K}_{2} \mathrm{O}\right) / \mathrm{Na}_{2} \mathrm{O}+\mathrm{K}_{2} \mathrm{O}+\mathrm{FeO}^{*}+\mathrm{MgO}^{-} ; \mathrm{F}, \mathrm{FeO} /\left(\mathrm{Na}_{2} \mathrm{O}+\mathrm{K}_{2} \mathrm{O}+\mathrm{FeO}+\mathrm{MgO}\right)$; $\mathrm{M}_{3} \mathrm{MgO} /\left(\mathrm{Na}_{2} \mathrm{O}+\mathrm{K}_{2} \mathrm{O}+\mathrm{FcO}^{*}+\mathrm{MgO}\right) ;-\infty$, not applicable; norm $\mathrm{An}$, an/(an + ab +or); $A b, a b /(a n+a b+o r) ; O r$, or $/(a n+a b+o r)]$

\begin{tabular}{|c|c|c|c|}
\hline Rock type & Andesite & Dacisc & Dacite \\
\hline Quadrangle & $\mathrm{C}-4$ & $\mathrm{C}-\mathrm{l}$ & $\mathrm{C}-4$ \\
\hline Ficld no. & 83 Fn49 & $81 B \cup 82$ & $83 \min 26$ \\
\hline \multicolumn{4}{|c|}{ Chemical analyscs (weight percent) } \\
\hline $\mathrm{SiO}_{2}$ & 48.73 & 60.97 & 63.51 \\
\hline $\mathrm{AJ}_{2} \mathrm{O}_{3}$ & 17.3 & 14.73 & 17.66 \\
\hline $\mathrm{FcO}$ & - & 2.27 & - \\
\hline $\mathrm{Pe}_{2} \mathrm{O}_{3}$ & -- & 1.42 & -- \\
\hline $\mathrm{MgO}$ & 7.06 & 1.82 & 2.68 \\
\hline $\mathrm{CaO}$ & 11.43 & 6.8 & 3,81 \\
\hline $\mathrm{Na}_{2} \mathrm{O}$ & 2.85 & 4.13 & 4.53 \\
\hline $\mathrm{K}_{2} \mathrm{O}$ & 0.14 & 0.55 & 1.84 \\
\hline $\mathrm{TiO}_{2}$ & 1.12 & 0.41 & 0.25 \\
\hline $\mathrm{P}_{2} \mathrm{O}_{5}$ & 0.1 & 0.14 & 0.09 \\
\hline $\mathrm{MnO}$ & 0.17 & 0.08 & 0.03 \\
\hline LOI & 1.45 & 4.54 & 3.21 \\
\hline $\mathrm{Fe}_{2} \mathrm{O}_{3}$ & 10.27 & - & 2.22 \\
\hline TOTAL & $\overline{100.62}$ & $\overline{97.86}$ & $\overline{99.83}$ \\
\hline $\mathrm{Na}_{2} \mathrm{O}+\mathrm{K}_{2} \mathrm{O}$ & 2.99 & 4.68 & 6.37 \\
\hline $\mathrm{FeO}$ & 9.22 & 3.55 & 1.99 \\
\hline $\mathrm{FcO}^{\circ} / \mathrm{MgO}$ & 1.3 & 1.9 & 0.7 \\
\hline A & 15.5 & 46.6 & 57.7 \\
\hline $\mathbf{F}$ & 47.9 & 35.3 & 18.1 \\
\hline M & 36.6 & 18.1 & 24.3 \\
\hline \multicolumn{4}{|c|}{ CIPW norms (weight percent) } \\
\hline$q(z$, & $\ldots$ & 21.0 & 18.9 \\
\hline or & 0.8 & 3.5 & 11.3 \\
\hline$a b$ & 24.5 & 32.4 & 39.7 \\
\hline an & 34.5 & 21.5 & 19.0 \\
\hline di & 18.2 & 11.1 & - \\
\hline hy & 9.2 & 2.1 & 6.9 \\
\hline ol & 6.5 & - & - \\
\hline mt & 3.9 & 2.2 & 0.8 \\
\hline il & 2.2 & 0.8 & 0.5 \\
\hline ap & 0.2 & 0.3 & 0.2 \\
\hline cor & -.- & - & 1.6 \\
\hline $\mathrm{hm}$ & - & - & 1.3 \\
\hline Norm An & 57.7 & 34.4 & 27.1 \\
\hline$A b$ & 40.9 & 60.0 & 56.8 \\
\hline$O_{5}$ & 1.4 & 5.6 & 16.1 \\
\hline
\end{tabular}


this foliation as dikes. Thesc intrusions are most commonly $<2 \mathrm{~m}$ thick, but, as in the region between Glacier and Gravel Creeks (Anchorage C-3 Quadrangle; rig. 3), may be as thick as $30 \mathrm{~m}$. Locally, these larger bodies have thermally metamorphosed the surrounding phyllite to a biotite hornfels.

Many felsites intruding rocks of the Chugacli Icrrane, particularly those near the fault contact betwcen the two terranes, are indistinguishable from those in the Peninsular terrane, which suggests that they may be cogenetic. Howcver, in contrast to Ielsites in the Peninsular terrane, olher Chugach ecrrane felsites (1) tend to be finc grained rather than microcrystallinc, (2) contain anhedral, equant plagioclase grains in the groundmass rather than subhedral, elongate grains, (3) are crowded porphyries containing up to 25 percent strongly zoncd andesine phenocrysts (composition determince by extinction angles), and (4) have carly rather than late Eocene K-Ar ages (sec below).

\section{Age, Correlation, and Interpretation}

The age of Pelsites intruding the Peninsular terrane is relatively well constrained. Felsitcs in the Anchorage Quadrangle intrude the Chickaloon Formation of late Paleocene age, but have not becn found ineruding the Eocene Wishbone Hill Formation in the Matanuska Valley (Barnes, 1962; Clardy, 1974). Numerous K-Ar age determinations support the field evidence. Hormblende from the Kings Mountain pluton, which intrudes the Cretaccous Matanuska Formation, has a latcst
Eocene K-Ar age of $37.7 \pm 1.1 \mathrm{Ma}$ (tablc 8 ). Wholerock $\mathrm{K}$-Ar ages of five other felsitc in rusions in the Matanuska Valkey arc also middle to late Eocenc and range beiween $37.5 \mathrm{Ma}$ and $45.5 \mathrm{Ma}$ (Silbernian and Grantz, 1984). Dacitic intrusions in the Talkecina Mountains have K-Ar ages on hornblende of $43.6 \mathrm{Ma}$ and $39.7 \mathrm{Ma}$.

The source of the magma for the felsitc inlrusives near the Matanuska Valley is uncertain. The primitive strontium isotopic composition for thesc felsites does not seem to reflect derivation by partial melting of contincntal crust (Silberman and Grant/, 1984).

Two K-As age detcrminations for felsitc intrusions in the Chugach torranc, the first on hornblende from a dike intruding the McHugh Complex, and the sccond on biolite from a pelitic hornfels adjacent to a sill in the Valdez Group, yicld minimum ages of $57.2 \pm 1.7 \mathrm{Ma}$ and $52.1 \pm 1.6 \mathrm{Ma}$, respectively (tablc 8). A felsite in the Valde\% Quadrangle yiclded a $\mathrm{K}-\mathrm{Ar}$ age on hornblende of 51.6 Ma (Winklcr and others, 1981b). These ages are distinctly older than those oblained from felsitcs in the Peninsular terrane to the north. These dald suggest that there may be al least two generations of silicic intrusions in the norflicentral Chugach Mountains. In the Vaidez Group, a medium-grained cquigranular suite of foliated tonalitic sills, possibly syntectonic with $S_{2}$, may represent an cverl bider generation of silicic plutons (sce bclow).

The 52-Ma to $57-\mathrm{Ma}$ nonfoliated Chugach terrane felsites may represent part of the Sanak-

Table 8. K-Ar ages from hypabyssal rocks of the nonhcentral Chugach Mountains

[A nalytical work for this sludy done under the dircetion of D.I. Turner, University of Alaska Geoplysical Instilute, Fairbanks, Alaska. Abbreviations include: ti - titanium; ho - homblende; -- not available\}

\begin{tabular}{|c|c|c|c|c|c|c|c|}
\hline Sample no. & Unit & Rock & $\begin{array}{c}\text { Mineral } \\
\text { datcd }\end{array}$ & $\begin{array}{c}\text { Age } \\
(m . y .)\end{array}$ & $\begin{array}{l}\% \mathrm{~K}_{2} \mathrm{O} \\
\text { avcrege }\end{array}$ & Quadrangic & Reference \\
\hline \multicolumn{8}{|c|}{ Tertiary felsite dikes } \\
\hline $82 J \mathrm{D} 386 \mathrm{a}$ & Tf & Andesite dike & llornblende & $57.2 \pm 1.7$ & 0.538 & c.3? & This study \\
\hline 82JD378r & $7 Y$ & $\begin{array}{l}\text { Hornfels adja- } \\
\text { cent to ande- } \\
\text { sile dike suite }\end{array}$ & Biotile & $52.1 \pm 1.6$ & 5.812 & C.3? & This siudy \\
\hline $82 I_{\mathcal{C}} 124$ & King Min & Ti granodioritc & Amphibolc & $37.7 \pm 1.1$ & 0.450 & D-4 & This study \\
\hline SIID Clark & $\pi$ & Hlb dacite & Ilornblende & $39.9 \pm 20$ & - & A-8 & Clark (1981) \\
\hline $\begin{array}{l}\text { Mafic dikes } \\
81 \text { AW } \times 516\end{array}$ & $\mathrm{I}^{\prime} \mathrm{Ja}$ & Basalt dikc & Whale rock & $38 \pm 2$ & 0.158 & D-4 & Winkler (1989) \\
\hline
\end{tabular}

\footnotetext{
-35 with lUGS constants
} 
Baranof belt of "near-trench" plutons that intrudes the Chugach and Prince William terranes (Hudson and Plafker, 1982). Strontium isotope data from plutons of this belt of silicic plutons, and their association with high-grade metamorphic rocks of the Valdez Group in the core of the St. Elias Mountains east of the Copper River, suggest that the plutons were derived from partial melting of deepscated rocks in the Chugach terrane (Hudson and Plafker, 1982). The Sanak-Baranof plutons of southern Alaska have K-Ar ages on biotite and hornblende between $47 \mathrm{Ma}$ and $52 \mathrm{Ma}$ in the St. Elias Mountains of eastern Alaska (Sisson and Hollister, 1985, 1986) and between $58 \mathrm{Ma}$ and $60 \mathrm{Ma}$ in western Alaska. The 52-Ma and 57-Ma ages for felsitc intrusions located between these two areas, including those in the study area, fall between the older and younger age groups, which supports their correlation with plutons in the Sanak-Baranof belt.

An older generation of tonalitic sills intrudes the higher grade parts of the Valdez Group east of the Copper River (Sisson and Hollister, 1985, 1986). These tonalitic sills are interpreted to have intruded at a depth of about $7 \mathrm{~km}$ and occurred between $64 \mathrm{Ma}$ and $59 \mathrm{Ma}$ (K-Ar on hornblende; Sisson and Hollister, 1985, 1986) syntectonically with the second foliation. These sills may be early forerunners of all felsites in the northcentral Chugach.

\section{STRUCTURAL GEOLOGY}

Rocks of the Peninsular and Cbugach terranes have bcen subjected to a complex sequence of brittle and ductile deformation ranging in age from Jurassic or older to Quateraary. The principal fault system in the Nelchina-Kings Mountain area, the Border Ranges fault system, forms the contact between the Peninsular and the Chugach terrane (MacKevett and Platker, 1974). The Border Ranges fault system is actually a composite fault system and bas a protracted history of both dip- and strike-slip movement in late Mesozoic and Tertiary time. The term "Border Ranges fault system" is here used descriptively to denote a system of faults which (1) locally separate rocks of the Peninsular terrane to the north from those of the Chugach terrane to the south and (2) cut rocks of both terranes to the north and south of that terrane boundary within a 5- to 10$\mathrm{km}$-wide zone of densely spaced faults. Some northand northwest-dipping faults within the Border Ranges fault system are probably remnants of an original Cretaceous age thrust contact between the Chugach and the Peninsular terrane (Mackevett and Plafker, 1974; Pavlis, 1982b). As discussed below, many faults within the Border Ranges fault system are part of a set of cast- or northeast-striking, nearvertical fauts. Such faults locally cut Lower Cretaceous tonalite-trondhjemite plutons, Lower Cretaceous McHugh Complex, Upper Cretaceous Matanuska Formation, Upper Cretaceous Valdez Group, and late Paleocene-early Eocene Chickaloon Pormation (Pessel and others, 1981; Burns and others, 1983; Pavlis, 1986; Little and Naeser, 1989). These post-Paleocene age faults are an important younger element of the Border Ranges fault system and include components of both normal and dextral strike-slip displacement.

In the structural descriptions below, the Peninsular and Chugach terranes are treated separately, and structural events affecting each terrane are described in inferred chronological order.

\section{PENINSULAR TERRANE}

The Pcninsular terranc has been involved in a complex sequence of brittle and ductile structural events ranging in age from Jurassic or older to Quatemary. The earliest recognized deformation of pre- to syn-Jurassic age occurred in an island arc environment. Later structural events are probably retated to Cretaceous inception of a convergent margin (or subduction zone) along the southern edge of the extinct Peninsular terrane arc (Pavlis, 1982b) and to Paleogene transpression and wrench-faulting along this margin. In the Peninsular terrane, structural events can be organized chronologically as follows: (1) Jurassic or older ductile deformation; (2) probable Early Cretaceous brittle deformation; (3) post-Jurassic uplift, crosion, and nortbward tilting; (4) Late Cretaceous and early Tertiary uplift and block faulting; (5) folding and faulting that postdates the late Paleocene-early Eocene Chickaloon Formation and pre-dates intrusion of late Eocene felsites; and (6) faulting that postdates intrusion of late Eocene felsites.

\section{DEFORMATION OF DOMINANTLY JURASSIC AGE}

\section{Metamorphic Rocks of Dominantly Jurassic Age}

The metamorphic rocks interpreted to be dominantly Jurassic in age (map units Mzh, Mza, Mzm, and Mzmp; sheets 1 and 2) are ductilely deformed. Some of the deformation may have occurred when the rocks were intruded by the Jurassic arc plutons. The rocks are characterized by 
a pronounced foliation that is axial-planar to closeor isoclinal-folds of compositional layering. Original bedding in thinly bedded chert/argillite sequences is now generally transposed parallel to a strong phyllitic foliation in the argillite (Pavlis, 1983; Little and others, 1986b). The fabric in greenschist and epidote amphibolite facies metabasaltic rocks and impure (biotite or hornblende-bearing) quartzofeldspathic rocks is weakly to strongly schistose. Amphibolite facies metabasaltic rocks are schistose or contain a strong gneissic layering defined by thin layers of amphiboles ( \pm pyroxenes) with either sodic plagioclase ( \pm quartz) or calc-silicates (Burns, 1983, in press; Pavlis, 1983, 1986; Little and others, 1986b). The metamorphic foliation, $S_{1}$, generally strikes in a northeasterly dircction and dips steeply to the northwest or southeast (fig. 9). F fold axes plunge gently (generally to the northeast) within the plane of the $S_{1}$ foliation. $F_{2}$ folds that locally warp the $S_{1}$ foliation commonly have a box or chevron geometry with apical angles that range from open to isoclinal (Pavlis, 1983). These folds, of unknown age, are approximately co-axial with $\mathrm{F}_{1}$ folds but have more gently dipping axial planes (Pavlis, 1982b). Textural relationships indicate that metamorphic minerals grew syokinematically with the strong $S_{1}$ foliation,

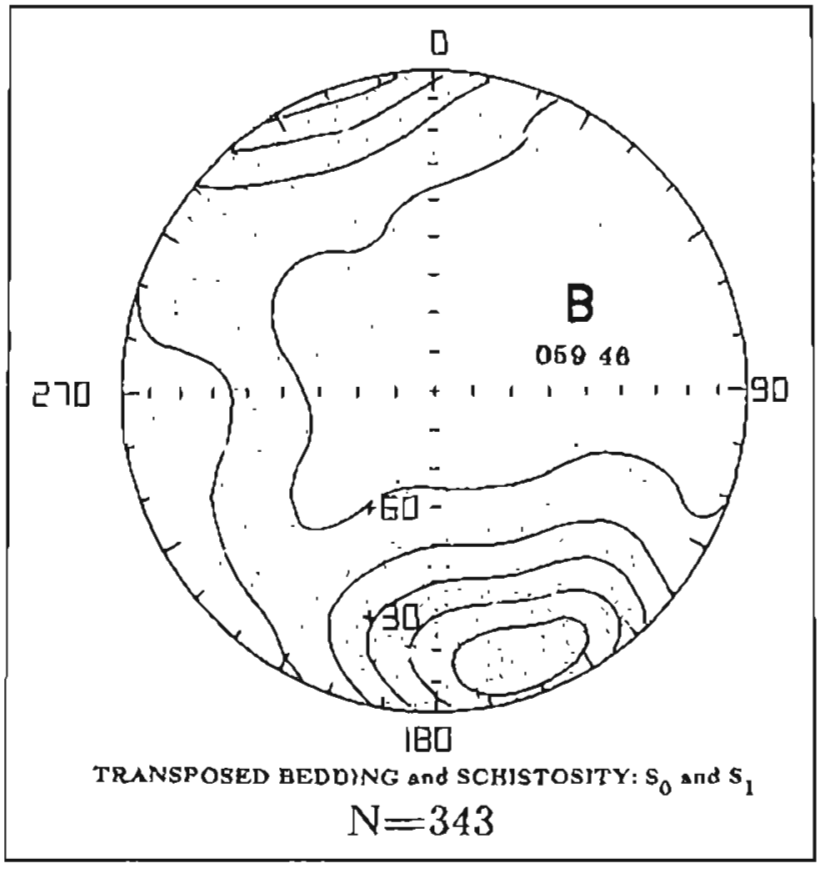

Figure 9. Synoptic stereogram of combined poles to schistocity $\left(S_{1}\right)$ and lightly folded bedding $\left(S_{0}\right)$ in preJurassic melamorphic (Mzsh) rocks of the Peninsular terrane. Contour intervals correspond to 2.0, 3.4, 4.7, and 7.3 percent per 1 percent area. but some mineral growth continued during late- or post-kinematic stages (Pavlis, 1983; Little and others, 1986b). In the Anchorage C-1, C-3, C-4, and $\mathrm{C}-5$ Quadrangles, these metamorphic rocks are intruded by dikes and stocks of gabbronorite, hornblende gabbro, and quartz diorite-tonalite. Inasmuch as all available geochronologic data indicates an Early to Middle Jurassic age for plutonic rocks of the Peninsular terrane, this regional metamorphism, penetrative deformation, and isoclinal folding must bave occurred in Jurassic time or earlier.

\section{Plutonic Racks}

Many of the Jurassic plutonic rocks are ductilely deformed (Buras, 1983, in press; also see Peninsular terrane-Jurassic plutonic section). A strong foliation is present in plutonic rocks of the Peninsular terrane, especially where multiple diking of Jurassic magmas has occurred (Burns, 1983, in press; Burns and others, 1983; Pavlis, 1986; Little and others, 1986b). These dike complexes range in composition from dominantly gabbroic to dominantly hornblende gabbro and tonalite. The foliation in these Jurassic age plutonic rocks is defined by (1) segregation of mafic and leucocratic minerals into thin laminae and (2) preferred dimensional alignment of elongate hornblende and plagioclase grains, the latter of which are commonly internally strained and partly recrystallized along their rins. Quartz in foliated (gneissic) tonalitic rocks occurs in anastomosiog laminae subparallet to the foliation and is commonly completely recrystallized into a granoblasticpolygonal mosaic. Ncar the Nelchina Glacier, the attitude of foliation in the pre-Jurassic metamorphic rocks is subparallel to the foliation in the plutonic rocks (Burns, 1983, in press). Elsewhere, the relationship of local foliation in plutonic rocks to the widespread $\mathrm{S}_{1}$ fabric in their associated metamorphic wall rocks is still poorly known. Many of the textures in the foliated plutonic rocks may represent flow foliation of in siru growth habits. Some of the foliation near the Nelchina Glacier (Anchorage C-1 Quadrangle) has been shown by Burns (1983, in press) to represent intrusions which were deformed while still partly molted. This concept has been further documented to the west in rocks of the Anchorage C-3 and C-4 Quadrangles by Burns and others (1983), Pavlis (1986), and Little and others (1986b).

\section{Volcanic Rocks}

A poorly understood deformation has affected the Lower Jurassic rocks of the Talkeetna 
Formation. Detailed mapping of the Talkeetna Formation has shown that the map pattern of strikes and dips is compatible with broad, open folds about axes that trend in an approximately north-south direction. These large-scale folds bave wavelengths of 1 to $10 \mathrm{~km}$ with axes that dip shallowly to the north. The origin and timing of this deformation is uncertain, but it appears to pre-date the Cretaceous brittle deformation. No evidence is seen for isoclinal folding within the Talkeetna Formation and, in general, the unit has undergone little ductile deformation.

\section{BRITTLE DEFORMATION OF PROBAHLE EARLY CRETACEOUS AGE}

Jurassic plutonic, volcanic, and metamorphic rocks are cut by a complex network of low- and moderate-angle faults along the southern margin of the Peninsular terranc. The rocks are intensely fractured, cataclastically deformed, and altered by subgreenschist and grcenschist facies mineral assemblages (Pavlis, 1983; Little, 1988). Pervasive brittle deformation and alteration is most intense within a several-kilometer-wide zone along the southern cdge of the Peninsular terrane in the Anchorage C-1 and C-2 Quadrangles (Pessel and others, 1981; Burns and others, 1983), but also occurs (at various scales) within the brittle shear zoncs throughout the Anchorage C-3, C-4, and C-5 Quadrangles (Burns and others, 1983; Pavlis, 1986; Little and others, 1986b). The brittle deformation can be classified into three groups: (1) low- to moderate-angle faults and cataclastic zones dipping $30^{\circ}$ to $70^{\circ}$ to the north that separate different map units; (2) low- to moderate-angle fauts and cataclastic zones dipping to the north that are within map units; and (3) mesoscopic-scale faults and cataclastic zones ( $<0.5 \mathrm{~m}$ thick).

The age of many of these low-to moderate-angle faults and associated low-grade metamorphism is probably post-Middle Jurassic and pre-Late Cretaceous. However, at least part of the deformation is of Tertiary age (see section below). A Cretaceous minimum age limit is constrained by two observations: First, low- to moderate-angle faulting and pervasive cataclasis generally does not affect Lower Cretaccous tonalite-trondhjemite plutons that locally intrude complexcs of plutonic rocks dismembered by brittle deformation (Pavlis, 1982b; Burns and others, 1983). East of the Matanuska Glacicr, a fault dipping gently to the north places rocks of the Talkeetna Formation on top of a tectonic complex of gabbroic rocks (sheet 2).
This fault is intruded locally by a swarm of trondhjemite dikes. A trondhjemite dike in the area yields a K-Ar age on bornblende of $145 \mathrm{Ma}$ (table 5), which suggests that the shallow-dipping fault may be older than middle Cretaceous. Secondly, clasts of cataclastically deformed plutonic rocks containing prehnite or pumpellyitc (typical of the metamorphism discussed below, associated with this brittle deformation) occur in the late Paleocene to Early Eocene age sedimentary rocks of the Chickaloon Formation.

The maximum age limit of the britle deformation is provided by the ages of the youngest rocks affected by the deformation, which range from $177 \mathrm{Ma}$ (K-Ar age on hornblende in mafic dike intruding plutons of quartz diorite-tonalite) to 155 to $160 \mathrm{Ma}$ (K-Ar ages on hornblende in quartz diorite pluton). These relationships suggest that pervasive brittle deformation occurred in post-Middle Jurassic to preLate Cretaceous time.

Faults of probable Cretaceous age within the Peninsular terrane rocks include discrete faults with narrow zones of cataclasis ( $<5 \mathrm{~m}$ wide) and brittle shear zones to $1.5 \mathrm{~km}$ wide consisting cbiefly of cataclastic rocks. The faults most commonly dip gently to moderately north. Displacement on these faults places Talkeetna Formation above quartz diorite or gabbroic rocks, and quartz diorite above gabbroic rocks. Such faults also internally dismember the Jurassic plutonic rocks and locally place Jurassic plutonic and metamorphic rocks of the Peninsular terrane above Cretaceous melange of the McHugh Complex, as in the area between Monument and Ninemile Creeks (fig. 3). Most of these low- to moderate-angle north-dipping faults along the southern edge of the Peninsular terrane are interpreted as tbrust faults, even though they do not always place older rocks over younger in the Jurassic arc rocks. Such faults presumably constituled an original Cretaceous brittle megathrust zone between the Peninsular cerrane and the underthrust Chugach terranes (MacKevett and Plafker, 1974; Pavlis, 1982b).

Many cataclastic zones are theraselves mappable units at 1:25,000 scale. Mapped, calaclastic shear zones within the Peninsular terrane include cataclastic gabbroic rock (TKgc), quartz diorite (TKcu), Talkeetna Formation volcanic rocks (TKvc), and sheared metamorphic rocks of pre-Jurassic protolith age (TKsm). These zones can be traced discontinuously from the Anchorage C-5 Quadrangle (Pavlis, 1982b, 1986) eastward to the Valdez Quadrangle (Winkler and others, 1981b) and increase in width and degree of deformation in the 
southern Peninsular terrane, where they gencrally lie within disrupted plutonic rock.

Widespread cataclastic deformation is typical in these tectonic complexes. The melange-like units consist of variable proportions of relatively intact blocks or phacoids from 10 to $100 \mathrm{~m}$ in dimension, surrounded by anastomosing zones of protocataclasite and cataclasite as wide as $10 \mathrm{~m}$. Original igneous textures and mineralogy are commonly preserved in the blocks and in small porphyroclasts in the matrix. The very fine grained greenish matrix is locally foliated, contains an abundance of anastomosing, slickensided surfaces, and ranges in texture from protocataclasite to ultracataclasite (Sibson, 1977). Blocks and matrix are both altered by pre- to post-cataclastic growth of new minerals in the prehnite-pumpellyitc facies (Pavlis, 1982b; Little, 1988). In the Anchorage C-5 Quadrangle, Pavtis (1982b, 1986) reported two brittle shear zones ("disrupted zones") as wide as $1.5 \mathrm{~km}$, consisting of a braided network of moderately northwest-dipping faults and cataclastic zoncs which are subparallel to the fault contact between the Peninsular and the Chugach terranes. Faults within these zoncs are characterized by a central core of intense cataclastic deformation, generasly $<50 \mathrm{~m}$ wide (Pavlis, 1982b). Typically, the cataclastic core of a fault is surrounded by a halo of subgrecnschist facies altered rock.

Prehnite-pumpellyite facies with minor lower grcenschist-facies assemblages are typical in the mafic to intermediatc composition cataclastic rocks occurring along faults throughout the southern Peninsular terrane. The assemblage of chlorite, epidote, prehnite, albite, quartz, sphene, \pm pumpellyite, \pm actinolite (optical and $\mathrm{X}$-ray diffraction data) alters and replaces original igneous grains in the very fine grained cataclastic matrix. Laumontite and calcite occur as late-stage fracture fillings and may be a much younger alteration product. Blocks of ultramafic rocks are variably serpentinized. This and similar assemblages exist in the altered cataclastic rocks across the map area, and thus the physical conditions during early cataclasis of the plutonic rocks were probably similar throughout a large portion of the belt.

As first suggested by Pavlis (1982b), these low- to moderate-angle fautts and cataclastic zones are interpreted as part of an original Cretaceous age megathrust between the Peninsular and the Chugach terranes. In the melange-like units east and west of the Nelchina Glacier (TKmc and TKgk on sheet 2; Pessel and others, 1981; Winkler and others, 1981b), blocks of $\mathrm{McHugh}$ Complex rocks, including radiolarian chert and pillow basalt, are juxtaposed against a melange composed of gabbroic rocks from the Peninsular terrane. Intermixing may occur. Pavlis (1986) reports a similar melange-like admixture of Chugach and Peninsular terrane rocks along their contact in the Anchorage C-5 Quadrangle. The style of brittle deformation and very low-grade alteration in the TKmc unit is similar to that affecting disrupted Peninsular terrane racks to the north. The similarity in metamorphic grade between the cataclastic rocks of the McHugh Complex and the cataclastic rocks of the gabbroic complex is consistent with the idea that brittle deformation in the Peninsular terrane occurred during underthrusting of the $\mathrm{McHugh}$ Complex along the Border Ranges fault system (Pavlis, 1982b).

\section{UPLIFT, EROSION, AND NORTHWARD TILTING OF POST.JURASSIC AGE}

A faulted cross section of the Jurassic are is present in the Nelchina-Kings Mountains area. Stratigraphicalty younger rocks of the are crop out to the north. The rocks of the Peninsular terrane are are tilted between $60^{\circ}$ and $90^{\circ}$ to the north. The general sequence of rocks north of the Chugach terrane, from south to north, is pre-Jurassic protolith age, metamorphic rocks and(or) ultramafic cumulate rocks, gabbroic rocks, quartz diorite and tonalite, and island-arc volcanic rocks. The volcadic rocks of the Jurassic arc, the Talkeetna Formation, are overlain by the Cretaceous Matanuska Formation, which crops out only in the northern part of the NelchinaKings Mountain area, and by the late Palcocencearly Eocene Chickaloon Formation.

Variations in this idealized sequence of the Jurassic rocks are probably related to lateral variations in the level of structural exposure and to widespread dismemberment of the sequence by postJurassic faulting. Locally, as in the area just west of the Matanuska Glacier, younger uplift has been less significant than in adjacent areas, and sedimentary rocks of the Chickaloon Formation cover the southern edge of the Peninsular terrane. The sequence of Jurassic and pre-Jurassic are lithologies indicates decreasing levels of structural exposure to the north and suggests that the Peninsular terrane was tilted to the north in post-Jurassic and prePaleocene time.

Stratigraphic evidence suggests that much of the northward tilting may have been associated with uplift of the southern Peninsular terrane during postMiddle Jurassic and pre-Albian time. As suggested by Pavlis (1982b), the regional pre-Albian 
unconformity at the base of the Matanuska Formation may represent an uplift of the Peninsular terrane during inception of the Border Ranges fault system. In the northern Chugach Mountains, the conspicuous omission of about $7 \mathrm{~km}$ of Middle Jurassic to Lower Cretaceous units which occur elsewhere in the Peninsular terrane (Grantz, 1960a,b; Detterman and Hartsock, 1966; Kirshner and Lyon, 1973; Detterman and Reed, 1980) suggests that the southern edge underwent a greater amount of erosion in pre-Albian time than did other parts of the Peninsular terrane (Little and Naeser, 1989). One migbt expect that thrust emplacement of the Chugach terrane bencath the Peninsular terrane would have resulted in both uplift and northward tilting of the southern edge of the Peninsular terrane on the hanging wall of the subduction zone (Karig and Sharman, 1975). The northward tilting of the Jurassic are sequence of the Peninsular terrane may thus have occurred during Cretaceous inception of the Border Ranges fault system.

The observed uplift and northward tilting of the Peoinsular terrane in the northero Chugach Mountains is of composite and, in part, younger origin (discussed below). Detailed mapping of Paleocene Chickaloon Formation and older rocks exposed along the present range front indicates that some uplifting and northward tilting is the result of south-side-up block-faulting and folding of latest Cretaceous and early Tertiary agc. Morcover, an even younger Neogene uplift of the Chugach Range has been postulated by Kirshner and Lyon (1973); Pavlis and Bruhn (1983); and Byrne (1986).

\section{UPLIFT, EROSION, AND FAULTING OF LATEST CRETACEOUS-EARLY EOCENE AGE}

A latest Cretaceous-late Paleocenc age event of uplift, erosion, and high-angle faulting in the Peninsular terrane can be inferred on the basis of sedimentologic and structural data. The late Paleoccne-early Eocene Chickaloon Formation consists chiefly of fluvial rocks and disconformably (locally unconformably) overlies marine sedimentary rocks of the Late Cretaceous Matanuska Formation. This erosional hiatus is exposed in the Matanuska Valley and in the northernmost Chugach Mountains (Waring, 1936; Grantz, 1961a,b; Barnes, 1962; Little and others, 1986b) and records an abrupt transition from marine to non-marine deposition that apparently occurred without significant folding or deformation other than block-faulting. Along the north flank of the Chugach Mountains, regional uplift during the time of the unconformity and during deposition of lower parts of the Chickaloon Formation was associated with south-side-up blockfaulting. Evidence for such high-angle faulting includes (1) abrupt changes in depositional basement beneath the Chickaloon Formation to older or structurally deeper lithologies in a southward direction; (2) local occurrence of stecply dipping faults with south-side-up displacement, which bound blocks of different basement type and which locally do not offset the lower parts of the Chickatoon Formation (Little, 1988); and (3) the observation that the Chickaloon Formation was an alluvial fan system derived largely from exposed metamorphic rocks of the Chugach terrane to the south. Thus the Chugach terrane was uplifted and subaerially exposed prior to and during deposition of the Chickaloon Formation. Moreover, the discontinuily in regional metamorphic grade across the Border Ranges fault system with respect to Late Crctaceous rocks of the Valde\% Group (greenschist facies) and Matanuska Formation (zeolite facies) suggests that the Chugach tcrtane has undergone more post-Late Cretaceous uplift and erosion than adjacent rocks of the Peninsular terrane. Uplift of the Valdez Group and south-side-up block-faulting along the northern edge of the Chugach terrane may have been caused by isostatic response to accretion of the large, tectonically thickened prism of low density metasedimentary rocks now represented by the Valdez Group (Little and Naeser, 1989). Alternatively, regional uplift of the Chugach terrane may have been related to possible ridge-trench interactions (such as subduction of the Kula-Pacific ridge), as has been proposed by Marshak and Karig (1977) and Moore and others (1983).

\section{FAULTING AND FOLDING OF POST-EARLY EOCENE AGE}

\section{Faulting}

Folded Palcocene rocks of the Chickaloon Formation are uplifted along the north flank of the Chugach Mountains and cut by higb-angle faults that strike subparallel to the trend of the range. The Chickaloon Formation is preserved in several fault blocks in the central part of the mapped area and in a strip along the northern edge of the range. The Anchorage C-2 and C-3 Quadrangles are the only area where such Tertiary age rocks are preserved in the northern Chugach Mountains. Most of our information regarding the nature of Tertiary faulting is therefore derived from detailed structural mapping 
studies in this region (Little, 1988). Post-early Eocene high-angle faults can be traced from this region into areas to the east and west, where only Jurassic and older crystalline rocks are exposed.

These Tertiary age faults are an important element of the Border Ranges fault system, as defined earlier. The average strike of these faults changes from approximately east-west in the eastcrn part of the mapped area, to northeast-southwest in the western part. The change in strike occurs in the axial region of an apparent oroclinal bend (Carey, 1955) that also affects the trend of the entire Chugach terrane along the southern rim of Alaska.

Most of these post-Paleocene faults are subvertical and are probably dominated by dextral (wrench) displacements (Littlc, 1988). In most cases, the amount of strike separation (or offset) of map units across high-angle faults in the Border Ranges fault system cannot be determined bccause (1) sedimentary units in the Peninsular terrane generally have an east-west stratigraphic strike, subparallel to the faults; (2) most of the rocks cut by the faults are plutonic units, which are discontinuous, nontabular, and without unique features; and (3) many of the faults also have a significant component of dip-slip displacement (discussed below) which results in mismatching of map units across the fault.

Several high-angle faults in the Peninsular terrane on the Anchorage C-3 and C 4 Quadrangles can be shown, from map pattern alone, to have a probable right-lateral displacement. Near the head of Carbon Creek, in the western part of the Anchorage C-4 Quadrangle and eastern part of the Anchorage C-5 Quadrangle (fig. 3; sheet 1 , cross section D.D'), Chugach terrane rocks of the McHugh Complex are fault-bounded on the north by the greatest width of Peninsular terrane metamorphic rocks in the mapped area (about $4 \mathrm{~km}$ iostead of the more usual 1 to $2 \mathrm{~km}$ ). An east-northeast striking high-angle faul, cutting through the middle of the exposed metamorphic rocks, separates two lithologically similar sub-belts of metamorphic rocks. The observed double width of metamorphic rocks appears to be the result of fault-repetition (in plan view) of a 2-km-wide metamorphic belt by the highangle fault. Two other map units (Jgu and $\mathrm{Kt}$; sheets 1 and 2) form a similar sequence (in plan view) on the north side of each of the two sub-belts of metamorphic rocks. Thus, a sequence of map uлits seems to be repeated in plan view across the fault (Little and others, 1986b, cross section A-A'). The mapped geometry (sheet 1 ) suggests a minimum of about $12 \mathrm{~km}$ of right-lateral strike separation. The contacts of the plutons (as deduced from map pattern), the mean attitude of foliation in the metamorphic rocks, and the fault itself are all nearly vertical, whereas observed slickenlines are subhorizontal; the observed separation is therefore the probable result of strike-slip rather than dip-slip displacement.

A second high-angle fault, with dextral strike separation, occurs between Glacicr and Gravel Creeks in the Anchorage C-3 Quadrangle (sheet 2). This east-striking, subvertical fault offsets an older normal fault that dips moderately south-southwest. The oormal fault places Paleocene Chickaloon Formation, to the south, on Jurassic quartz diorite, to the north, with Talketna Formation not present (cross section $\mathrm{H}-\mathrm{H}$ ', sheet 2). The younger subvertical fault apparently offsets the normal fault about $1.5 \mathrm{~km}$ in a right-lateral sense. This separation has resulted in a repelition (in plan view) of the trace of the normal fault and emplacement of a narrow sliver of Chickaloon Formation within a mass of quartz diorite (sheet 2). The younger subvertical fault surface is cxhumed, where its trace crosses the west-flowing tributary to Gravel Creek. Here, that east-striking fault surface contains slickenlines that plunge within a few degrees of horizontal, suggesting that the observed separation is due to strike-slip rather than dip-slip displacement. In the Anchorage C.3 and C-4 Quadrangles west of Gravel Creek, Little (1988) reports a small trondhjemite stock is displaced about $6 \mathrm{~km}$ across a fault-bounded sliver of Chickaloon Formation.

In the central Chugach Mountains, the faute contact between the Peninsular and the Chugach terranes is probably a dextral oblique-slip fault with a south-side-up component of normal displacement. Between Gravel Creek and the Matanuska Glacier (shect 2), rocks of the Chickaloon Formation occur along the southern edge of the Peninsular terrane. Here, the fault contact between the Peninsular and the Chugach terranes dips $60^{\circ}$ to $75^{\circ}$ to the northnorthwest (sheet 2; cross section J-J') and is demonstrably of post-early Eocene age, because it downdrops sedimentary rocks of the Chickaloon Formation against greenschist facies metamorphic rocks of the Valdez Group. The metamorphic rocks have early Eocene $\mathrm{K}$-Ar ages on melamorphic white mica (Little and Naeser, 1989). The Chickaloon Formation has been completely eroded away from the southern block (Chugach terranc). Although the terrane-bounding fault on the basis of mapped relationships, vitrinite reflectance, and the metamorphic mineral assemblage data, probably has a large dextral strike-slip displacement, it also has at 
least $3 \mathrm{~km}$ of normal throw of post-early Eocene age (Little and Naeser, 1989). In detail this fault is a braided zone of stecply dipping, complexly intershuffled fault slices (Little, 1988).

Figure 10 shows one possible kircmatic model to explain the distribution of rock units in a ceneral part of the map area that invokes fault-bend folding of strikc-slip fault blocks during an infcrred $13 \mathrm{~km}$ of dextral-slip along a major nonplanar fault in the Border Ranges faull system. Descriptions of fault geometries and kinematics in greater detail may be found in Little (1988). The change in mean strike of post-early Eocene faults in the Border Ranges fault system across the map area corresponds to the apparent hinge of southern Alaska's orocline; thus, the age of that structure appears to be post-early Eocene (Little and Naeser, 1984).

\section{Folding}

Throughout the area of its exposure in the northern Chugach Mountains, the Chickaloon Formation is folded about gently plunging, castnortheast to northeast-trending axes which lie within nearly upright axial planes. The folds are oblique 10 east-northcast to cast-west-striking high-angle faults and are arranged in an en echelon pattern; these folds die out rapidly to the north away from the Border Ranges fault system. This geometry probably reflects development of these folds within a zone of distributed right-lateral wrench deformation along the Border Ranges fault system. The folds have wavelengths on the order of 0.5 to $1 \mathrm{~km}$ and a concentric or chevron morphology. Except in areas where local depressions and culminations affect the binge lines of these folds, areas where the folds die out into lateral terminations, or arcas where thcy have been deformed by demonstrably younger folding, the folds are very nearly cylindrical in their geometry. Axial traces form an acute angle of less than $45^{\circ}$ against adjacent cast or east-northeast striking high-angle faults. The axial planes of some nearly isoclinal folds form angles of $10^{\circ}$ or less with adjacent faults and have probably been rotated within zones of greater strain. Locally, small-scale transverse-normal faults and conjugate scts of strikeslip faults symmetrically transect the wrench folds, causing their axial elongation.
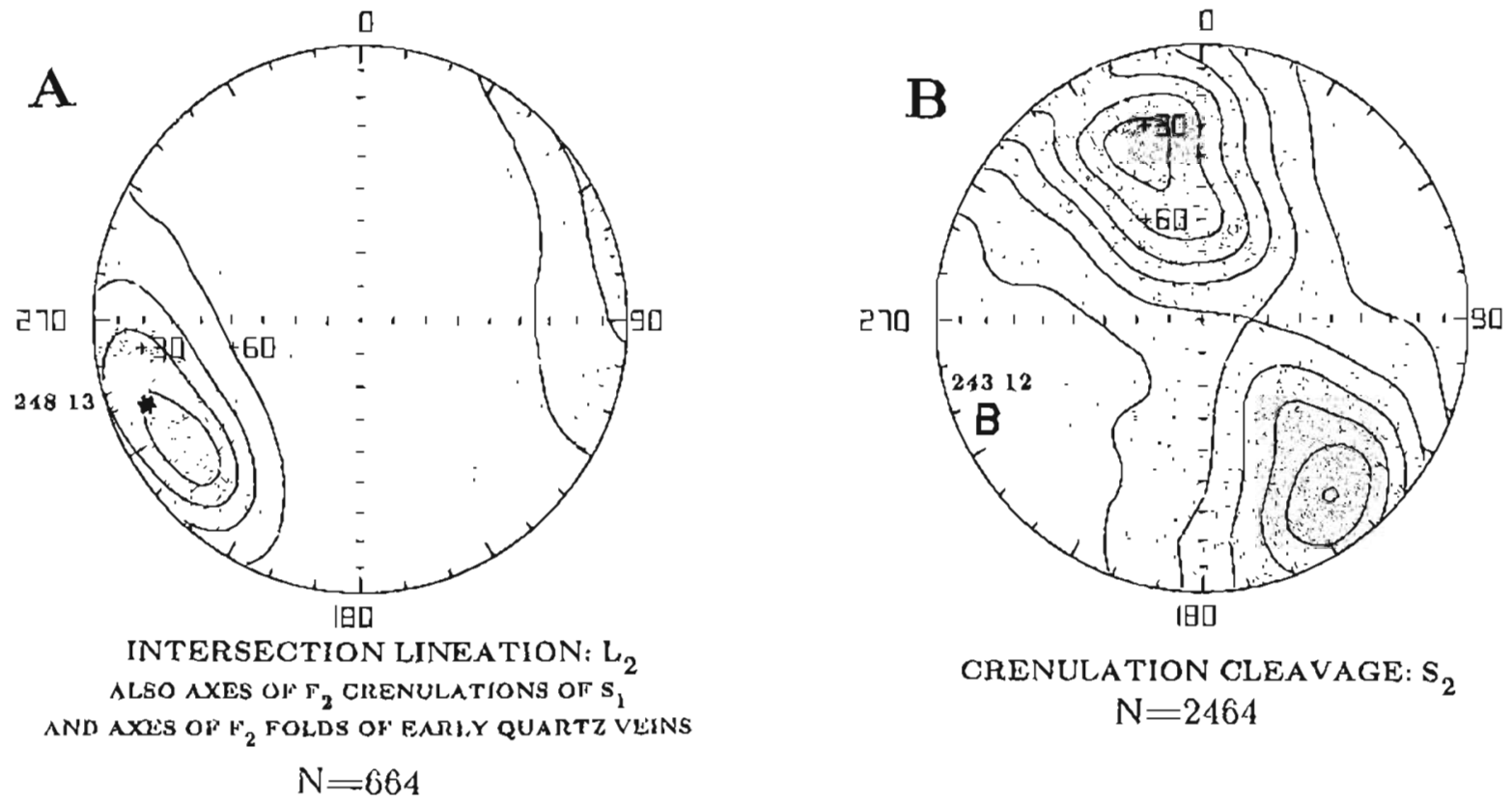

Figurc 10. Contoured lower-hemisphere equal-area slereograms of poles 10 schistosity $\left(S_{2}\right)$ and lineation $\left(\mathrm{L}_{2}\right)$ in the Crelaceous subduction complex (Chugach terrane). Mean values determined by conputer using the cigenvalue of Woodcock (1977). $A_{1} L_{2}$ lineations in the Valdez Group defined by the intersection of $S_{1}$ and $S_{2}$ at comtour intervals of 3.5, 5.8, 8.1, and 110.4 percent per 1 percent area; asterisk locates mean lineation. B, poles to schistosity $\left(S_{2}\right)$ in the Valdez Group at contour intervals of 1.0, 1.7, 2.4, 3.1, 3.8, and 4.4 percent per 1 percent area. $B$ indicates best-fit B axis to girdled distribution resulting from map-scale $F_{4}$ chevron. 
The en echelon folds in the carly Eocenc Chickaloon Formation are locally crosscut by faults intruded by the late Eocenc felsites. Thus, the faults are probably completcly Eocenc in age (Little, 1988). Further north in the Matanuska Valley, a syndinorium of broad, longer-wavelength, upright anticlines and synclines with east-northeast trending axial traces deforms the Matanuska and Chickaloon Formations, and, locally, the post-carly Eocene-age Wishbone Hill Formation (Barnes and Payne, 1956; Grantz, 1961a,b; Barnes, 1962). These folds are probably younger than the en cchclon folds within the Border Ranges fault system and formed during a late Paleogene-Neogene period of north-south shortening across the Malanuska Vidlcy (Bruhn and Pavlis, 1981). For a more detailcd description of polyphase folding of the Chickaloon Formation within the Border Ranges fault system, see Little and Naeser (1989) and Little (1988),

Wrench and oblique-slip faulting and en echelon folding of the Chickaloon Formation is probably no younger than Eocenc. The principal evidence for this conclusion is that felsite dikes with $\mathrm{K}$-Ar ages on hornblende and biolite of 30 to $37 \mathrm{Ma}$ (Silberman and Grantz, 3984; Litle, unpubl. data) intrude or cut across high-angle faults and only rarcly are cul by faults. The relationship of Eocene inlrusions to folds is generally equivocal. West of the Matanuska Glacier, a pluton of felsite intrudes the axial region of an anticline in the Chickaloon Formation, which suggests that the fold controlled (and therefore predales) intrusion of the pluton. Moreover, the faulting and folding appear to be related to the same tcctonic event; thus, the folding also is probably prelate Eocene in age.

\section{FAULTING THAT POSTDATES INTRUSION OF LATE EOCENE FELSITES}

Fauits that cut the late Eocene felsite intrusions but do not cul Ouatcrnary deposits are gencrally cast-west striking, steeply dipping faults. Bccausc such faults are uncommonly observed, little is known about Neogenc faulting in the northern Chugach Mountains. The clastic stratigraphy of the Neogene Kenai Group in Cook Inlet Basin (Calderwood and Fackler, 1972; Kirshner and Lyon, 1973; Boss and others, 1976; Hayes and others, 1976) reflecls Miocene and Pliocene uplift of the Chugach Range. Pavlis and Bruhn (1983) summarize data from the Kenai Peninsula for south-side-up high-angle faulting along the Кепаi-Chugach range frone during this time. Apatite fission-track data in the Anchorage $\mathrm{C}-3, \mathrm{C}-4$, and D-4 Quadrangles indicate that presently exposed rocks in the Chugach Mouniains were not cuoled below about $100^{\circ} \mathrm{C}$ until carly Miocene time. This observation, coupled with the widespread occurrence of laumontite in the Chickaloon Formation, a mincral characteristic of burial metanorphism, led Litle and Naeser (1989) to interpret over $4 \mathrm{~km}$ of Miocene to recent uplift and erosion in the northern Chugach Mountains.

High-angle faules of demonstrable Quatcrnary age occur locally in the northern Chugach Mountains (scc, for example, Updike and Ulery, 1983) and do not appear to have more than 1 to $2 \mathrm{~m}$ of displacement. These laults are gencrally expressed as trough-like linear depressions cutting across tundra-clad colluvial deposits. Such faults are most common along the cresi of the Chugact Range front in the arca belween Ninemile and Gravel Crecks. At this location, the Quaternary faules arc high-angle features, culting down into the Chickaloon and Talkecena Formations. On a ridgetop about $1 \mathrm{~km}$ east of the Monumcut Creck drainage, one such fault offscts the surface of a stceply south-dipping slope approximatcly $1.5 \mathrm{~m}$ vertically, with a south-sidc-up movement. This sense of vertical separation is opposite to that which would be expected for a simple land scarp.

\section{CHUGACH TERRANE}

The Chugach terrane (Berg and others, 1972) of Cretaccous age is exposed continuously for $2,000 \mathrm{~km}$ along the soulhern rim of Alaska and represenis one of the best-prcserved ancicnt subduction complexes in the world (Nilson and Zuffa, 1982). The Chugach tcrrane is the most landward, uplifted portion of a wide accrctionary prism that, in a general way, is younger in a seaward direction lowards the present trench. Low-grade mctamorphic rocks of the Chugach terrane adjacent to the Border Ranges fault system have been subjected to a complex scquence of ductile and brittle deformational events occurring initially during accretion to the leading edge of the continental margin and subsequenty within more interior parts of the growing accretionary prism. Late-stage cvents include dextral wrench deformation of probable Tertiary age that is similar to that affecting early Eocene and older rocks in the Peninsular terrane to the north.

Structures in the Chugach terrane can be organized by decreasing age into the following categories: (1) Cretaccous deformation affecting the McHugh Complex; (2) latest Cretaceous-Eocene polyphase events alfeding both units of the Chugach torrane, but nol the Peninsular terrane; and 
(3) Paleogene faulting and folding of Chugach tcrrane rocks similar to that affecting carly Eocene and older rocks in the Peninsular terrane.

\section{CRETACEOUS DEFORMATION AFFECTING THE MCHUGH COMPLEX}

The McHugh Complex in the Nelchina-Kings Mountain region is highly deformed and characterized by stratigraphic discontinuity of units with a variety of brittle-to-ductile structural styles (Clark, 1972a; Connelly, 1978; Decker, 1980; Burns and others, 1983; Pavlis, 1982a, 1986; Little and others, 1986b). The highly disrupted nature of the McHugh Complex contrasts markedly with the Valdez Group, which is generally coherent at the outcrop scale of observation. Except locally, as near its thrust contact with underlying rocks of the Valde's Group, the McHugh Complex is gererally not characterized by a cleavage fabric. Common brittle structural styles in the McHugh Complex include broken formation (or densely faulted rock) and block-in-matrix melange. Broken formation in the Mchlugh Complex is denscly faulted on an outerop scale, but lacks a block-in-matrix structure. Pervasive faulting has resulted in a complex mixing of fault blocks of greenstone, mafic metatuff or graywacke, lesser black argillite, and minor impure chert. Anastomosing networks of densely spaced mesoscopic-scale faults, many of them tectonically polished, are associated with cataclastic textures and locally divide the $\mathrm{McHugh}$ Complex into lensoidal blocks or phacoids (Pavlis, 1985). Where the $\mathrm{McH}$ ugh Complex is a true block-in-matrix melange, the matrix consists of black argillite, fine-grained grcen metatuff, and, locally, (hin-bedded siliceous argillite or impure chert. Melange blocks consist of greenstone, metatuff, graywacke, chert, impure limestone, and locally dioritic to ultramafic plutonic rocks. Brittle deformation of uncertain age, possibly Tertiary, is also representcd by post-fold, late-stage systems of quartz and calcitc-filled veins, which are locally a significant feature in the overall strain in the rocks (Pavlis, 1986).

The above-described brittle structures probably developed penecontemporaneously with other more ductile structures in the McHugh Complex. Black argillaceous rocks typicalty contain rootless laminae or wisps of green metatuff that have a complexly swirled or disharmonically folded morphology which, in the absence of any tectonic foliation, is suggestive of "soft-sediment" deformation. Chere beds are typically boudinaged or folded, or both. Such folds are generally tightly appressed to isoclinal.
This "soft-sediment" deformation and occurrence of subgreenschist facies metamorphism in melange of the Chugach terrane has been interpreted as having formed in deeper parts of a subduction zone (Moore and Connclly, 1977; Connelly, 1978; Decker, 1980). The age of early deformation in the accretionary McHugh Complex probably spans a long period of time in the Early Cretaccous and possibly extends back into older Mesozoic time. The K-Ar ages of 110 to $135 \mathrm{Ma}$ on the intrusion of post-tectonic tonalite-trondhjemite (discussed earlier) suggest that deformation of the McHugh Complex in a subduction zone and its underthrusting bencalh the Peninsular terrave occurred prior to late Early Crelaceous time. This pre-Early Cretaceous accretionary event was probably associated with formation of the densely spaced faults and cataclastic zones that disrupt crystalline rocks along the southern edge of the Peninsular terrane (Pavlis, 1982b). Inasmuch as the Valdez Group was not deposited until Late Cretaceous lime, its deformation is clearly younger than much of that affecting the McHugh Complex.

\section{DEFORMATION AFFECTING BOTH THE MCHUGH COMPLEX AND VALDEZ GROUP}

Later stages of deformation of the McHugh Complex are similar to the deformation of the Valdez Group. The first two of three remaining deformational events are recognized only in the rocks of the Chugach terrane. These two events produced dominantly ductile deformation. For simplicity, the terminology for the Valdez Group deformation ( $S_{1}, S_{2}$, and so on) will be used when discussing the similar deformation in the McHugh Complex

The age of the two-phase deformation sequence to form $S_{1}$ and $S_{2}$ is post-Maestrichtian (age of Valdez Group protolith) to early Eocene. A preearly Eocene age for the $F_{1}$ deformation is provided by the probable late Paleocene-early Eocenc age of Chickaloon Formation unconformably overlying $S_{1-}$ deformed rocks of the Valdez Group west of the Nelchina Glacier. Elsewhere, phyllitic rock fragments (probably $S_{1}$-deformed rocks of the Valdez Group) are a common constituent of the late Paleocene-early Eocene Chickaloon Formation (Little, 1988). An early Eocene upper age limit for the $F_{2}$ deformational event in the central Chugach Mountains is established from carly Eocene K-Ar ages of $52 \mathrm{Ma}$ and about $57 \mathrm{Ma}$, respectively, for biolite and hornblende, ages of felsite dike intrusions that postdate $S_{Z}$ in the Valdez Group (table 8), and a 
K-Ar age of about $57 \mathrm{Ma}$ on white mica growing along $S_{2}$ (Little, 1988).

\section{Valdez Group}

In contrast to widespread brittle deformation affecting most other units in the Chugach Mountains, deformation in the Valdez Group is chiefly ductile in nature, at least at a mesoscopic scale of obscrvation. As first noted by Decker (Buras and others, 1983), Valdez Group rocks in the central part of the sorthern Chugach Mountains have been penctratively deformed twice and contain two cleavages. Pavlis (1982b, 1986) also notcd two (and locally three) cleavages in the western Chugach Mountains. The intensity of the second and younger cleavage, $\mathrm{S}_{2}$ (a crenulation cleavage), increases markedly, from only partial or local development in the southwest part of the Anchorage C-5 Quadrangle to widespread development in the eastern part (Pavlis, 1985, 1986). Farther cast, in the Anchorage C-3 Ouadrangle, $S_{2}$ occurs pervasively and is the predominant cleavage observed in the Valder. Group (Little, 1988). S2 appears to decline in intensity east of the Matanuska Glacicr (in the eastcrn Anchorage C-2 Quadrangle) and is only a minor fabric in the Anchorage C-1 Quadrangle.

S1-forming event.-In the northern Chugach Mountains, the first deformational event in the Valdez Group resulted in widespread development of a penetrative cleavage $\left(S_{1}\right) . S_{1}$ is characterized by thin $(1$ to $3 \mathrm{~mm}$ ) laminae of phyllosilicate-rich and quartz-rich material that alternate with one another to form a finely banded rock. Veins of whilc quartz \pm albite(?) \pm chlorite up to $10 \mathrm{~cm}$ thick commonly constitute 3 to 5 percent of the total rock volume and are generally subparallel to, but locally crosscut $S_{1}$. Several generations of white quartz veins probably formicd penecontemporaneously with the $S_{1}$ cleavage, which is, in part, a pressure solution cleavage. Where bedding can be seen (as defined by silty or psammitic layers), it is generally subparaliel to the first foliation, suggesting that $F_{1}$ folds, which presumably formed in association with the $S_{1}$ cleavage, are approximately isoclinal. Because much of the Valdez Group in the mapped area consists of phyllite, and original bedding is rarely traceable in the field, little is known about the nature or geometry of $F_{1}$ folds in this region.

Pavlis (1986) implied that the $S_{1}$-forming deformational event in the western Chugach Mountains may not bave been accompanied by significant ( $\left.F_{1}\right)$ folding and was, instead, characterized by imbricate thrusting. However, south of the report area, near Mit. Marcus Baker, the presence of isoclinal folds within imbricate thrust slabs is well established. Inasmuch as the outcrop width of Valdez Group rocks across this part of southern Alaska represents an immense structural thickness of Maestrichtian age clastic sediments, duplication by imbricate thrusting of an originally several-kilometer-thick sedimentary section is an appealing bypothesis, but is here difficult to demonstrate.

$S_{2}$-forming event.-The cleavage of the first deformational event is folded into disharmonic open folds, with low amplitude to wavelength ratios, and into compressed and isoclinal folds, with a locally well developed axial-planar cleavage $\left(S_{2}\right)$. This second clcavage is predominantly a spacedcrenulation cleavage, but locally is penetrative and breaks along micaceous surfaces. The second cleavage $\left(S_{2}\right)$ is best observed where formed at a high angle to the first cleavage $\left(S_{1}\right)$ and is particularly wcll displayed in the rocks with a shaly protolith. This crenulation cleavage, $S_{2}$, is the most conspicuous mesoscopic fabric element of the Valdex Group throughout most of the central part of the Nelchina-Kings Mountain region. Development of $S_{2}$ in the Valdez Group was contemporaneous with the lower greenschist facies regional metamorphism (Decker, in Burns and others, 1983; Litule, 1988). The spaced $S_{2}$ cleavage is zonal to discrete, and planar to anastomosing in morphology (Borradaile and others, 1982). Long limbs of asymmetric microfolds of $S_{1}$ lie within cleavage domains and are rotated to small angles with respect to cleavage domain boundarics. The short limbs and hinges of $\mathrm{F}_{2}$ microfolds commonly lie within microlithons and intersect cleavage domain boundarics at relatively bigh angles. Microlithons are generally about $1 \mathrm{~cm}$ wide or less, but locally they are as wide as $4 \mathrm{~cm}$. Like $S_{1}, S_{2}$ is a differentiated cleavage for which pressure solution was an important formation process, and cleavage domains are markedly depleted in quartz and feldspar with respect to adjacent microlithons. A few quartz veins appear to have formed penecontemporaneously with $S_{2}$. The intersection of $S_{1}$ and $S_{2}$ commonly defines a faint lineation $\left(\mathrm{L}_{2}\right)$, which is parallel to the axes of associated small-scale plications ( $F_{2}$ folds) of $S_{1}$. In the central Chugach Mountains, the attitude of $S_{2}$ is not uniform, because that cleavage has been folded into younger map-scale folds $\left(F_{3}\right)$ with axes that plunge gently west-southwest (sheet 2). Thus, on the limbs of these later folds, $S_{2}$ generally dips either to the northwest or southeast (fig. 10b). 
$S_{2}$ is axial planar to $F_{2}$ folds. $F_{2}$ folds are defined by (1) small-scale plications or microfolds of $S_{1}$, as described above; and (2) mesoscopic folds of white quartz veins subparallel to $S_{1}$. In general, $F_{2}$ fold axes (and $\mathrm{L}_{2}$ intersection lineations) plunge $10^{\circ}$ to $30^{\circ}$ within $S_{2}$, most commonly to the west-southwest (fig. 10a). These harmonic folds generally have hinges that are angular to rounded in shape and tectonically thickened with respect to adjacent, nearly straight cold limbs. Mulsiple orders of $\mathrm{F}_{2}$ folds are present, and their wavclength and amplitude are a function of the thickness of the folded layers. Where several-centimeter-thick quartz veins are the dominant nember, $F_{2}$ folds typically have wavelengths between 4 and $15 \mathrm{~cm}$, and amplitudes between 2 and $10 \mathrm{~cm}$. These folds are close to isoclinal. More competent, silty or psammitic lithologies are less tightly folded, more sinusoidal in profile, and ofecn have no $S_{2}$ cleavage.

\section{Interpretation}

The McHugh Complex locally is affected by the same two-phase deformation sequence described above (Decker, in Burns and others, 1983). The fact that both Valdez Group $S_{1}$ and $S_{2}$ clcavages are present in the McHugh Complex indicates that the Valde\% Group and the McHugh Complex were juxtaposed by $S_{1}$ time, and that the origin of the two clcavages is the same in both units.

Superposition of the $S_{1}$ and $S_{2}$ fabrics onto McHugh Complex melange seems to have been accompanied by an overprint of lower grecnschist facics metamorphism. The restriction of the strongest such overprints affecting the McHugh Complex melange to a narrow bell adjacent to its fault contact with the Valdez Group suggests that this latest Crctaceous-Paleocene age polyphase overprint was associated with episodes of fault displacement between the Valdez Group and the McHugh Complex. Moore and Wheeler (1978) have described a similar faust-related foliation overprinting Chugach terrane melange on Kodiak Island. There, a foliation overprints the Uyak Complex (a correlative of the McHugh Complex) in a narrow belt adjacent to its thrust contact with the Kodiak Formation (a correlative of the Valdez Group).

In the Chugach Mountains, the McHugh Complex commonly rests in low-angle thrust contact above rocks of the Valdez Group (Clark, 1972a; Winkler and olhers, 1981b). Northward underthrusting of the Valdez Group along this fauk (or faults) in latest Cretaceous-Paleocene time
(Moore, 1973, 1978; Plafker and others, 1977) was probably associated with development of $S_{1}$ and resulted in accretion of the Valdez Group to the continental margin along the inner wall of an oceanic treach (Moore, 1973, 1978) or decper in a subduction zone along a zone of duplex development and underplating (Sample, 1985). Where the unit is largely unaffected by later deformations, the cleavage generally dips to the north or northwest, as is consistent with its development during northward under-thrusting (Moore, 1973, 1978; Budnik, 1974; Plafker and others, 1977; Nokleberg and others, 1985; Sample, 1985). The early slaty cleavage affecting Chugach terrane flysch has been best studic on Kodiak Island, where there is evidence that it developed when the rocks were in semilithified state (Moore, 1973, 1978; Sample, 1985).

$S_{2}$ in the northern Chugach Mountains may be analagous to the dominant schistosity or gneissic foliation affecting higher grade metamorphic rocks of the Valde' Group in the eastern Chugach and St. Elias Mountains (Hudson and others, 1977; Plafker and others, 1977; Hudson and Plafker, 1982). In this area, as in the northern Chugach Mountains, the dominant foliation overprints an earlier cleavage, which presumably developed during accretion of the Valdez Group and is postdated by 43- to 52-Ma-old granodioritic intrusions of the Sanak-Baranof belt (Hudson and Plafker, 1982). In the eastern Chugach and St. Elias Mounlains, the age of this dominant foliation is approximated by K-Ar ages of 48 to 53 Ma for synkinematic minerals in the Valdez Group (Winkler and others, 1981b; Hudson and Plafker, 1982). Sisson and Hollister (1985) reported foliated conalitic sills that intruded the Valdez Group prior to the Sanak-Baranof piutons and during development of $\mathrm{S}_{2}$. These older sills may be analagous to similar, foliated tonalitic sills intruding the Valdez Group in the northern Chugach Mountains (see section on Tertiary felsite intrusions).

A second (crenulation) cleavage of early Tertiary age seems to characterize the Valdez Group (and its correlatives) (hroughout much of the area of its exposure along the rim of southern Alaska. In general, where such crenulation cleavage has not becn much affected by later deformations, it has been described as dipping moderately or steeply to the southeast of south (Budnik, 1974; Nokleberg and others, 1985; Pavlis, 1985; Sample, 1985). In the central part of the northern Chugach Mountains, post- $F_{2}$ folding (discussed below) has obscured the original orientation of the $S_{2}$ cleavage. The $S_{2}$ cleavage in the Valdez Group is about the appropriate agc (early Eocene) to be related to 
accretion and deformation of Paleogene age turbidites of the Orca Group (Helwig and Emmct, 1981) against the contincntal margin in the area of Prince William Sound.

\section{DEFORMATION OF CHUGACH TERRANE ROCKS SIMILAR TO THAT AFFECTING EARLY EOCENE AND OLDER ROCKS IN THE PENINSULAR TERRANE}

Post-S faulting and folding of the Chugach terrane is similar to that scen in the Peninsular terrane. Faults are generally stceply dipping and form part of the Tertiary Border Ranges fault systcm. Folds of $S_{2}$ in the Chugach terrane are generally large, uprighe, chevron-style folds $\left(\mathrm{F}_{3}\right)$ with southwest-trending axes and kilometer-scale wavelengths, similar to folds in the Chickaloon Formation. Locally, small-scale parasitic $\left(F_{3}\right)$ folds also exist.

\section{Faulting}

In the northern Chugach Mountains, rocks of the Chugach terrane are involved in high-angle laulling along the Border Ranges fault systcm. Many of these faults are probably dextral wrench faults of post-early Eocene age, similar to those alfecting nearby rocks of the Peninsular tcrranc. Inasmuch as most high-angle faults cut the latest Cretaccous age Valdez Group, they are probably of carly Tertiary or younger age. In the upper parts of Coal and Carbon Creeks, an east-striking high-angle fault has about 4 $\mathrm{xm}$ of dextral strike separation with respect to the trace of a low-angle faule (the Eagle River fault) placing McHugh Complex rocks above the Valdez Group (Decker, in Litcle and others, 1986b).

Similarly, Pavlis (1986) noted that in the Anchorage C-5 Quadrangle another northeaststriking high-angle fault crosscuts the Eagle River fault and results in about $5 \mathrm{~km}$ of dextral strikc separation of the trace of the Eaglc River fault. Clearly, some of these strike separations could be due to dip-slip movements on the fault, but, as noted by Pavlis (1986), this fault is only part of a system of high-angle faults that form a fault network consisicnt with cast-northeast-striking master faults and caststriking riedel shears developed along a dextral shear system.

About $13 \mathrm{~km}$. of dextral displacement along a non-planar wrench fault near the boundary between the Peninsular and Chugach terranes may have resulted in fault-bend folding of a block of McHugh Complex and Peninsular terrane rocks as they rode over a bend in the fault (Little and others, 1986a). In the central part of the mapped area in the Anchorage $\mathrm{C}-3$ and $\mathrm{C}-4$ Quadrangles (fig. 3, sheets 1 and 2; near cross section $E-E^{\prime}$ and south of cross section $G-G^{\prime}$ ), a right-stepping bend in the trace in the Border Ranges fault system is convex northward and coincides with the northern fault boundary of a lenticular body of the McHugh Complex (fig. 11). At the eastern end of this convexity, this lensoid mass of the MclHugh Complex pinches out and is separaled by a nearly vertical fault from the Vaidez Group to the south. To the north, the lenticular body is in fault contact with the Chickaloon Formation and other rocks of the Peninsular terrane. Detailed structural mapping on the east side of the convexity shows that the Z-shaped deflection of the Chickaloon Formation and a corresponding abrupt bending of cleavage in the McHugh Complex is the result of large-scalc kinking about several subvertical kinkband boundaries that strike to the northeast and northwest. The relationship (in map vicw) of these kinks to the high-angle fault north of the Valdez Group is similar to that observed (in vertical section) for fault-bend folds in the hanging wall of a thrust shect to an underlying horizontal decollement (Suppe, 1983). The shape and dimensions of this fault-bend fold system suggest about $13 \mathrm{~km}$ of dextral displacement along the fault contact between the Valdez. Group and the McHugh Complex. Moreover, if the model is correct, it requires that this subvertical fault continue westward with an abrupt, left-stepping bend somewhere in the region of upper Coal Creek. North-northeast-striking thrust contacts placing McHugh Complcx above Valdez Group in that area may be transpressional features, as should be expected along such a restraining bend.

\section{Folding}

An en echelon system of map-scale antiforms and synforms deforms $S_{2}$ in the Valdez Group. This system of late upright folds within the Valdez Group was first described by Decker (in Burns and others, 1983) and has been shown to be a regionally extensive class of structures within the Valdez Group (Winkler and others, 1981b). The system is described in detail by Little (1988). In the Anchorage C-2 and C-3 Quadrangles, these folds have gently plunging axes that trend west-southwest or southwest and lie within subvertical axial planes (fig. 10B). Little (1988) considers the folds to be $F_{4}$, ranging from chevron to box in their profile shape. Apparent step-like deflections in the axial trace of these folds (sheet 2 ) are rclated in part 10 regional 
strain variations affecling the original orientation of folds and in part to local development of multi-hinge, box-fold geometrics.

The gcometry, orientation, and age of these folds is indistinguishable from post-early Eocene age wrench folds $\left(F_{1}\right)$ deforming the Chickaloon Formation. The age of $F_{3}$ in the Valdez Group is constrained to post-early Eocene (probable age of $S_{2}$ foliation) on the basis of K-Ar ages on white mica (Little, 1988).

\section{SUMMARY AND CONCLUSIONS}

The Border Ranges fault system, one of the major structural featurcs in south-central Alaska, cuts through the center of the Nelchina-King Mountain region. This fault system separates the trench-slope and trench-fill deposits of the Chugach terrane from the plutonic and volcanic rocks of the Peninsular terrane.

The Peninsular terrane includes the oldest rocks in the region, a structurally dismembered sequence of mctasedimentary and metavolcanic rocks. These rocks comprise a mctamorphic suite of upper greenschist to amphibolite grade, and appear to have formed in an oceanic environment. The age of these rocks is uncertain, but is probably pre-Jurassic, possibly Triassic or late Paleozoic. The metamorphism is probably atuributable to Early Jurassic magmatism in the Peninsular terrane.

Magmatism and volcanism in an intraoccanic island arc setting occurred in the Peninsular terrane by Early Jurassic time. Early intrusion of basaltic magma probably started near the crust-mantle boundary, and fractional crystallization produced ultramafic and mafic plutonic rocks of the Wolverine complex and the Nelchina River Gabbronorite. Residual magma from this cvent, mixed with new magma, probably moved to shallower levels in the crust and differentiated to produce the volcanic rocks of the Talkectna Formation. Successive intrusions of basaltic magma contributed additional material to the plutonic and volcanic rocks. The mineralogy and mineral composition of the plutonic rocks suggest that they crystallized at 5 to 10 kilobars of pressure

Figurc 11. Stylized map sections showing present distribution of $\mathrm{McHugh}$ Complex, Peninsular terrane, and Valdez Group in arca of convexnorthward bend of the Border Ranges faull sysiem and inferred fault-bend folding model in central part of sundy area. Note left-stepping bend in strikeslip fault and its right-lateral offset of Eagle River thrust fault at base of the McHugh Complex. Heavy dashed line in the McHugh Complex is present-day trace of basal thrust fault. Solid soothed line to the south is inferred original trace of thrust fant prior to uplift and erosion along left-slepping bend of the sirike-slip faull; this dip-slip morion is inferred to have reduced the anount of rightlateral separation of the thrist trace across the sirike-slip faull.

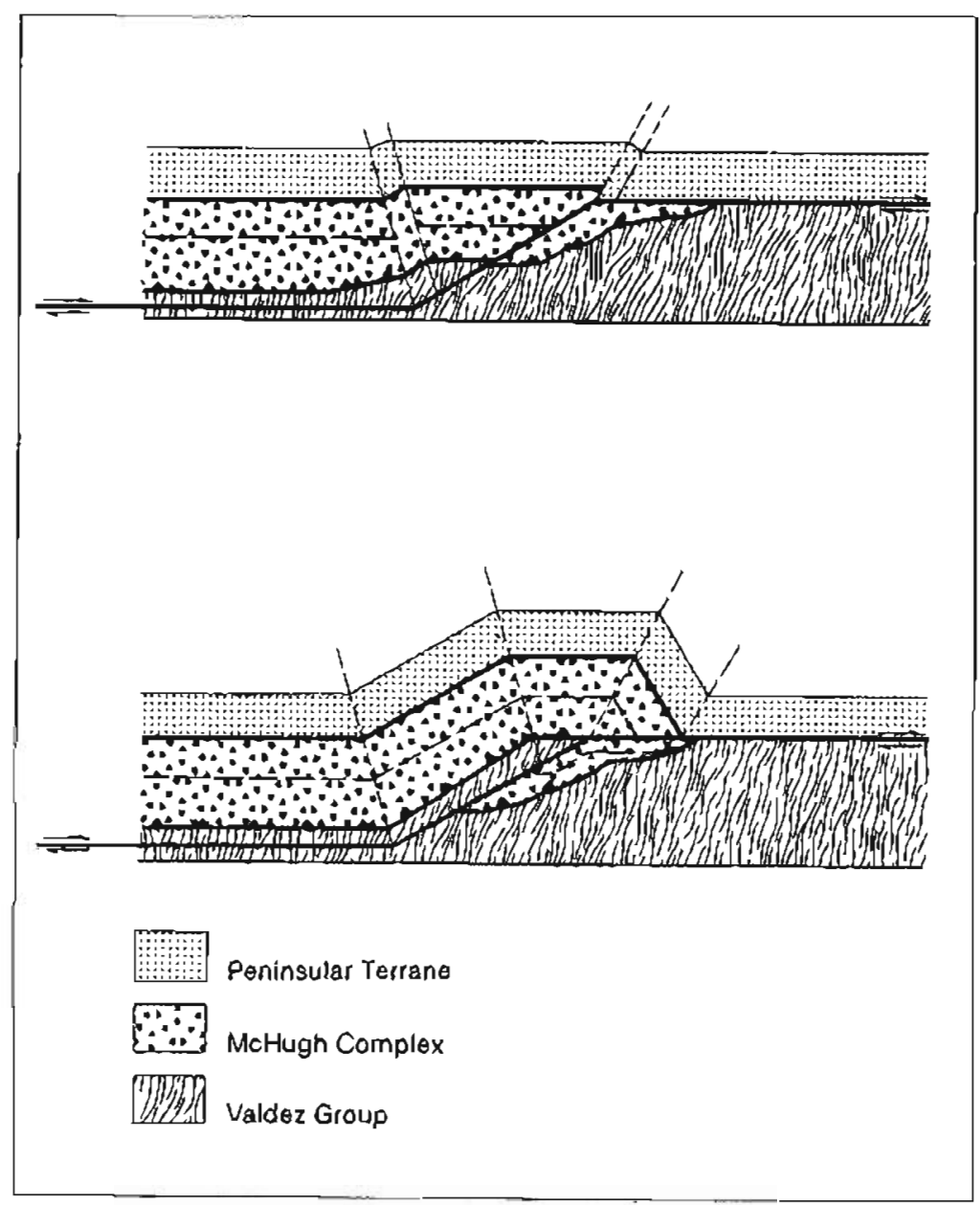


(15 to $30 \mathrm{~km}$ depth). Textures of the gabbroic rocks and the associated metamorphic rocks also support the hypothesis of deep-seated intrusion.

Quartz diorites, tonalites, and minor granodiorites intruded the mafic plutonic rocks and the volcanic rocks of the Talkeetna formation in later Jurassic time. Ductile deformation of the gabbroic rocks suggests that intrusion of the quartz diorites took place early in the cooling phase of the mafic rocks. The source of the magma for the plutonic rocks of intermediate composition is not known. Possibilities include extreme differentiation of the original basaltic magma, partial melting of cither new mantle material or old oceanic crust, and mixing of these various materials. In any case, the plutonic suite of intermediate rocks may be associated with the Talkeetna-Aleutian batholith.

The island arc became inactive by Early to Middle Jurassic time. Between Middle Jurassic and late Early Crctaceous time, a convergent margin was formed along the southern edge of the extinct island arc of the Peninsular tcrrane. Deformation of oceanic rocks, trencb slope, and trench fill sediments took place in a subduction wedge at the convergent margin, and resulted in the subduction melange of the Mchugh Complex. Deformation in the subduction wedge formed a large zone of rocks exhibiting cataclastic textures and other features typical of brittle shear. Tectonism associated with this subduction zone probably caused the uplift, northward tilting, and erosion of the rocks of the extinct island arc in the southern edge of the Peninsular terrane. Thrusting of crystalline rocks of Peninsular terrane over the subduction melange represented by the $\mathrm{McHugh}$ Complex apparently occurred at this time. This thrust faulting represents the earliest phase of the Bordcr Ranges fault system.

Cessation of this tectonism at the southern edge of the Peninsular terrane is evidenced by intrusion of tonalite-trondhjemite plutons ( 125 to $100 \mathrm{Ma}$ ) into the shear zones associated with the subduction zone. During Late Cretaceous time, sheif deposits of the Matanuska Formation were deposited on the eroded surface of the Jurassic arc complex. Continental margin sedimentation and continued convergence to the south of the Border Ranges fault system, resulted in underthrusting of trench-fill sediments of the Valdez Group under the McHugh Complex in latest Cretaceous to Paleocene time. This underthrusting was probably associated with the first of two phases of nearly isoclinal folding of the Chugach terrane sediments. This event was associated with an axialplanar cleavage. A second folding event resulted in a second axial-planar cleavage and a crenulation cleavage along with lower greenschist metamorphism in early Eocene time.

Rapid uplift and subaerial exposure of the Chugach terrane occurred in post-Maestrichtian and pre-late Paleocene time, during or soon after emplacement of the Valdez Group. Block-faulting, with uplift to the south, also occurred along the Border Ranges fault system, Alluvial fan sediments of the Chickaloon Formation of late Paleocene to early Eocene age were deposited across this blockfaulted region. The alluvial fans had local sources, in part from the uplifted Chugach terrane to the south.

In post-early Eocene to pre-late Eocene, dextral wrench-faulting occurred in the zone of the Border Ranges fault system. Available data suggest a displacement of no more than a few tens of kilometers. The occurrence of the wrench-faulting indicates a change in the direction of convergent plate motions.

Felsic dikes and sills of late Eocene age intrude both the Peninsular and Chugach terranes, including the shear zones along the Border Ranges fault system. Lack of deformation of these intrusives indicates that little motion has occurred along the fault system since that time.

Major faulting, associated with plate convergence, has occurred to the south of the northern Chugach Mouatains in post-Eocene time, along more outboard parts of the accretionary prism. Some minor faulling has occurred in the Nelchina-Kings Mountain region since that time, but does not appear to have becn of very large displacement. The later phases of faulting have resulted in the uplift of the soft sediments of the McHugb Complex and the Valdez Group to an elevation higher than the crystalline rocks of the adjoining Peninsular terrane. This uplift defines the southern side of the graben system of the modern Matanuska Valley, at the northeastern edge of the Cook Inlet basin.

\section{ACKNOWLEDGMENTS}

This research was made possible in part by National Science Foundation Grant Numbers EAR 80-01076 and EAR 81-15522, issued to N.H. Sleep. George Plafker of the USGS kindly provided unpublished field data from stations along the Border Ranges fault to help start the project. Discussions with R.G. Coleman, R.R. Compton, Arthur Grantz, E.L. Miller, Steve Nelson, N.H. Sleep, and Fred Barker, proved invaluable. Diana N. Solie and Mark Robinson kindly reviewed the manuscript. We would like to thank Mike Arline of TransAlaska Helicopters, our trusty, faithful helicopter pilot who was always there with coffee, 
J.C. Pesscl for many meals and hospitality, Mike and Mark Meekin of Alaska Wilderness Safaris and Don Decring for camp logistics, and fixed-wing and horseback transportation.

\section{REFERENCES}

Avé Lallemant, H.G., 1976, Structure of the Canyon Mountain (Oregon) ophiolite complex and its implications for sea-floor spreading: Geological Society of America Special Paper 173, 49 p.

Barker, Fred, Arth, J.G., Pelerman, Z.E, and Friedman, Irving, 1976, The 1.7 to 1.8 b.y. old trondhjcmite-basalt suite of southwestern Colorado and northern New Mexico: Geo. chemistry and depths of genesis: Geological Society of America Bulletin, v. 87, no. 2, p. $189-198$.

Barker, Fred, and Grantz, Arthw, 1982, Talkeetna Formation in the southeastern Talkeetra Mountains, southern Alaska: An Early Jurassic intraoceanic island arc [abs.]: Geological Society of America Abstracts witb Programs, v. 14, no. 4, p. 147.

Barnes, F.F., 1962, Geologic map of lower Matanuska Valley: U.S. Geological Survey, Miscellancous Geologic Investigations Map I-359, scale 1:63,360, 1 sheet.

Barnes, F.F., and Payne, T.G., 1956, The Wishbone Hill districh, Matanuska coal field, Alaska: U.S. Gcological Survcy Bulletin 1016, 88 p., 20 plates.

Berg, H.C., Jones, D.L., and Richter, D.H., 1972, Gravina-Nutzotin bclt: Tectonic significance of and upper Mesozoic sedimcntary and volcanic sequence in southern and southcastera Alaska: U.S. Gcological Survey Profcssional Paper 800-D, p. D1-D24.

Borradaile, G.H., Bayly, M.B., and Powell, C. McA., eds., 1982, Atlas of deformational and metamorphic rock fabrics: New York, SpringerVerlag, $551 \mathrm{p}$.

Boss, R.F., Lenoon, R.B., and Wilson, B.W., 1976, Middle Ground Shoal dil field, Alaska: in North American oil and gas ficlds: American Association of Petrolcum Geologists Memoir 24, p. 1-22.

Bruhn, R.L., and Pavlis, T.L., 1981, Late Cenozoic deformation in the Malanuska Valley, Alaska: Threc dimensional strain in a forearc region: Gcological Socicly of America Bulletin, v. 92, no. 5, p. 282-293.

Buddington, A.F., 1959, Granite emplacement with special reference to North America: Geological
Society of America Bulletin, v. 70, no. 6, p. 671.747.

Budnik, R.T., 1974, The geologic history of the Valdez Group, Kenai Peninsula, Alaska: Dcposition and deformation at a Late Cretaceous consumptive plate margin: Los Angeles, University of California at Los Angeles, Ph.D. thesis, $166 \mathrm{p}$.

Burns, L.E., 1981, Gravity and aeromagnetic modeling of a large gabbro body in the northeast Anchorage and north Valdez Quadrangles, Alaska: Stanford, Stanford University, M.S. thesis, $97 \mathrm{p}$.

1983, The Border Ranges ultramafic and mafic complex plutonic core of an intraoceanic island arc: Stanford, Stanford University, Ph.D. thesis, $150 \mathrm{p}$.

1985, The Border Ranges ultramafic and mafic complex, south-central Alaska: Cumulate fractionates of island-arc volcanics: Canadian Journal of Earth Science, v. 22, p. 1020-1038.

Geology of gabbroic rocks near the Nelchina Glacier, south-central Alaska: U.S. Geological Survey Bulletin [io press].

Burns, L.E., Little, T.A., Newberry, R.J., Decker, John, and Pessel, G.H., 1983, Preliminary geologic map of parts of the Anchorage C.2, C.3, D-2, and D-3 Quadrangles, Alaska: Alaska Division of Geological and Geophysical Surveys Report of Investigations 83-10, scale 1:25,000, 3 sheets.

Byrne, Tim, 1986, Eocene underplating along the Kodiak shelf, Alaska: Tectonics, v. 5, p. 403-421.

Calderwood, K.W., and Fackler, W.C., 1972, Proposed stratigraphic nomenclature for Kenai Group, Cook Inlet basin, Alaska: American Association of Pctroleum Geologists Bulletin, v. 56, no. 4, p. 739-754.

Capps, S.R., 1927, Geology of the upper Matanuska Valiey, Alaska: U.S. Geological Survey Bulletin 791, $92 \mathrm{p}$.

Carden, J.R., and Decker, John, 1977, Tectonic significance of the Knik River schist ccrrane, south-central Alaska: Alaska Division of Geological and Geophysical Surveys Gcologic Report 55, p. 7-9.

Carey, S.W., 1955, The orocline bypothesis in geotectonics: Procecdings of the Royal Society of Tasmania, v. 89, p. 255-288.

Christensen, N.I, and Salisbury, M.H., 1979, Seismic anisotropy of the oceanic upper mantle; Evidence from the Bay of Islands ophiolite complex Journal of Geophysical Rescarch, v. 84, no. B9, p. $4601-4610$. 
Clardy, B.I., 1974, Origin of the lower and midele Tertiary Wishbone and Tsadaka Formations, Matanuska Valley, Alaska: Anchorage, Univcrsily of Alaska-Anchorage, M.S. thesis, 74 p.

Clark, S.H.B., 1972a, Reconnaissance bedrock geologic map of the Chugach Mountains near Anchorage, Alaska: U.S. Geological Survey Miscellaneous Field Studies Map MF-350, scalc $1: 250,000,1$ sheel.

1972b, The Wolverine Complex, a nowly discovered layered uttramafic body in the western Chugach Mountains, Alaska: U.S. Gcological Survey Open-file Report 522, 10 p., scalc 1:63,360, 1 shect.

1973, The McHugh Complex of soutlicrn Alaska: U.S. Geological Survey Bufletin 1372-D, $11 \mathrm{p}$.

1983, Reconnaissance gcologic map of the Chugach Mountains in the Anchoragc C- 5 and C-6 Quadranglcs, Alaska: U.S. Gcological Survcy Open-file Report 83-0336, scalc 1:63,360, 1 shect.

Coleman, R.G., and Burns, L.E., 1985, The Tonsina high-pressure mafic-uleramalic cumulate scquence, Chugach Mountains, Alaska [abs.]: Geological Socicty of America, Cordillcran Section, Abstracts with Programs, v. 17, no. 6, p. 348 .

Connelly, William, 1978, Uyak Complex, Kodiak Islands, Alaska: A Crctaccous subduction complex: Gcological Socicty of America Bullclin, v. 89 , no. 5 , p. $755-769$.

Conwell, C.M., Triplehorn, D.M., and Ferrel, V.M., 1981, Coals of the Anchorage Quadrangle, Alaska: Alaska Division of Geological and Geophysical Survcys Spccial Report 17, 8 p., scale 1:250,000, 4 plates.

Csejtey, Bèla, Jr., Nclson, W.H., Jones, D.L., Silberling, N.J., Dcan, R.M., and Morris, M.S., 1978, Reconnaissance geologic map and geochronology, Talkectna Mountains Quadrangle, northern part of Anchorage Quadrangle, and southeast corncr of Healy Quadrangle, Alaska: U.S. Geological Survey Open-file Report 78-558A.

Decker, John, 1980, Gcology of a Cretaceous subduction complex, western Chichagof Island, southeast Alaska: Stanford, Stanford University, Ph.D. thesis, $135 \mathrm{p}$.

Detlerman, R.L., and Hartsock, J.K., 1966, Gcology of the Iniskin-Tuxedni region, Alaska: U.S. Geological Survcy Professional Paper 512.

Detterman, R.L., and Recd, B.L., 1980, Stratigraphy, structure, and economic geology of the Iliamna Quadrangle, Alaska: U.S. Geological Survey Bulletin 1368-B.
Fishcr, M.A, and Magoon, L.B., 1977, Geologic framework of lower Cook Inlct, Alaska: American Association of Pcerolcum Geologists Bulletin, v. 62, no. 3, p. 373.402.

Flynn, L.R., and Pessel, G.H., 1984, Petrology and geochemistry of intermediatc composition plutonic rocks in the northers Chugach Mountains, southcentrál Alaska: Geological Society of America Abstracts with Programs v. 16, no. 5, 283 p.

Fuchs, W.A., 1980, Terliary lectonic history of the Castle Mountain-Caribou fault system of the Talkeetna Mountains, Alaska: Salt Lake City, University of Utah, Ph.D. thesis, 162 p.

Gcorge, R.P., 1978, Siructural petrology of the Olympus ultramalic complex of the Troodos ophiolitc, Cyprus: Gcological Socicty of America Bulletin, v. 89, no. 6, p. 845-865.

Gill, J.B., 1981, Orogenic andesites and plate (cctonics: New York, Springer-Verlag, 390 p.

Giradeau, J., and Nicolas, A., 1981, The structures of two ophiolite nuassifs, Bay of Islands, Newfoundland: a model for the occanic crust and upper mantle: Tectonophysics, v. 77, no. 1-2, p. 1-34.

Grantz, Arthur, 1960\%, Gcologic map of the Talkeetna Mountains A-2 Quadrangle, Alaska, and the contiguous area to the north and northwest: U.S. Gcological Survey Misccllaneous Geologic Investigations Map I-313, scalc 1:48,000. $1960 \mathrm{~b}$, Geologic map of the Talkeetna Mountains A-1 Quadrangle, and the south third of the Talkeetna Mountains B-1 Quudrangle, Alaska: U.S. Geological Survcy Miscellancous Gcologic Investigations Map I-314, scale 1:48,000. 1960c, Gencralized geologic map of the Nclchina arca, Alaska, showing igncous rocks and larger faults: U.S. Geological Survey Miscellancous Geologic Investigations Map I-312, scale $1: 96,000$.

1961a, Gcologic map of the north twothirds of the Anchorage D-1 Quadrangle, Alaska: U.S. Geological Survey Miscellaneous Geologic Investigations Map I-343, scalc 1:48,000.

1961b, Geologic map and cross sections of the Anchorage D.2 Quadrangle and the northeasternmost part of the Anchorage D-3 Quadrangle, Alaska: U.S. Geological Survey Miscellancous Geologic Investigations Map I-342, scale $1: 48,000$.

1964, Stratigraphic reconnaissance of the Matanuska Formation in the Matanuska Valley, Alaska: U.S. Geological Survey Bulletin 1181-I, p. I1-I33. 
1966, Strike-slip faults in Alaska: U.S. Geological Survey Open-file Report 267, scale $1: 96,000,4$ sheets.

Grantz, Arthur, Stcrn, T.H., and Sheffey, N.B., 1963, Potassium-argon and lead-alpha ages for stratigraphically bracketed plutonic rocks in the Talkcetna Mountains, Alaska: U.S. Geological Survey Professional Paper 475-B, p. B56-B59.

Hartman, D.C., Pessel, G.H., and McGee, D.L., 1972, Prcliminary report on stratigraphy of Kenai Group, Upper Cook Inlct, Alaska: Alaska Division of Geological and Geophysical Surveys Special Report 5, 5 p., scale 1:500,000, 7 sheets.

Hawkins, D.B., 1973, Sedimentary zeolite deposits of the Upper Matanuska Valley, Alaska: Alaska Division of Geological and Geophysical Surveys Special Report 6, 17 p., scale 1:63,360, 1 shect.

Hayes, J.B., Harms, J.C., and Wilson, Thomas Jr., 1976, Contrasts between braided and meandering stream deposits, Beluga and Sterling Formations (Tertiary), Cook Inlct, Alaska, in Milicr. T.P., ed., Recent and ancient sedimentary environments in Alaska: Alaska Geological Society, Symposium Procecdings, p. J1-J17.

Helwig, James, and Emmet, Peter, 1981, Structure of Early Tertiary Orca Group in Prince William Sound and some implications for the plate tectonic history of southern Alaska: Journal of the Alaska Geological Society, v. 1, p. 12-35.

Hill, M.D., Morris, J.D., and Whelan, Joscph, 1981, Hybrid granodiorites intruding the accretionary prism, Kodiak, Shumagin, and Sanak Islands, southwest Alaska: Journal of Geophysical Rescarch, v. 86, no. 11, p. 10569-10590.

Hudson, T.G., 1979, Mesozoic plutonic belts in southern Alaska: Gcology, v. 7, p. 230-234.

Hudson, T.G., and Plafker, George, 1982, Paleogenc metamorphism of an accretionary flysch tcrranc, eastern Gulf of Alaska: Geological Socicty of America Bullelin, v. 93, no. 12, p. 1280-1290.

Hudson, T.G., Plafker, George, and Turner, D.L., 1977, Metamorphic rocks of the Yakutal-St. Elias area, southcentral Alaska: U.S. Geological Survey Journal of Research, v. 5, no. 2, p. 173-184.

Hudson, T.G., and Arth, J.G., 1989, Unpublished $\mathrm{U}-\mathrm{Pb}$ and $\mathrm{K}-\mathrm{Ar}$ ages for samples of plutonic rocks for the Anchorage Quadrangle, U.S. Geological Survey.

Irvinc, T.N., 1982, Terminology for layered intrusions: Journal of Petrology, v. 23, p. 127-162.

Irvine, T.N., and Baragar, W.R.A., 1971, A guide to the chemical classification of the common volcanic rocks: Canadian Journal of Earlh Science, v. 8, p. 523-548.
Jones, D.L., Silberling, N.J., Berg, H.C., and Plafker, George, 1981, Map showing tectonostratigraphic terranes of Alaska, columnar sections, and summary description of terranes: U.S. Geological Survey Open-file Rcport 81-792, 21 p., scale 1:2,500,000, 2 sheets.

Jones, D.L., and Clark, S.H.B., 1973, Upper Cretaceous (Maestrichtian) fossils from the Kenai-Chugach Mountains, Kodiak, and Shumagin Islands, southern Alaska: U.S. Geological Survey Journal of Research, v, 1, по. 2, p. 125-136.

Jones, D.L., and Siberling, N.J., 1979, Mesozoic stratigraphy - the key to lectonic analysis of southern and central Alaska: U.S. Geological Survey Opcn-file Report 79-1200, 40 p.

Karig, D.E., and Sharman, G.F., 1975, Subduction and accretion in trenches: Geological Society of America Bullctin, v. 86, no. 3, p. 377-389.

Karl, S.M., Decker, John, and Jones, D.L., 1979, Early Cretaceous radiolarians from the McHugh Complex, southeentral Alaska, in Johnson, K.M., and Williams, J.R., cds., The U.S. Geological Survey in Alaska: Accomplishments during 1978: U.S. Gcological Survey Circular 804-B, p. B88-B90.

Kirschner, C.E., and Lyon, C.A., 1973, Stratigraphic and tectonic development of Cook Inlet petroleum province, in Arctic Geology: American Association of Petroleum Geologists Memoir 19, p. 396-407.

Kuno, Hisashi, 1968, Origin of andesite and its bearing on the island arc structure: Bulletin Volcanologique, v. 32, p. 141-175.

Little, T.A., Blome, C.D., and Wolfe, J.A., 1986a, Paleocene-Eocene sedimentation and wrench tectonics along the Border Ranges fault system, north-central Chugach Mountains, Alaska [abs]: Geological Society of America Abstracts with Programs, v. 18, no. 2, p. 127.

Litlle, T.A., Pessel, G.H., Newberry, R.J،, Decker, John, and Burns, L.E., 1986b, Preliminary geologic map of parts of the Anchorage C.4 and C-5 Quadrangles, Alaska: Alaska Division of Geological and Geophysical Surveys Public-data File 86-28, scale 1:25,000, 1 sheet.

Litule, T.A., 1988, Geologic and structural bistory of the north-central Chugach Mountains during Cretaceous and Early Tertiary time [Ph.D. dissertation]: Stanford University, Stanford, California, $343 \mathrm{p}$.

Little, T.A., and Naeser, C.W., 1989, Tertiary ectonics of the Border Ranges fault system, southern Alaska: Deformation and uplift in a 
forearc setting: Journal of Geophysical Research, v. 94, p. $4333-4360$.

MacKevett, E.M., Jr., and Plalker, George, 1974, The Border Ranges fault in south-central Alaska: U.S. Geological Survey Journal of Research, v. 2 , no. 3, p. 323-329.

MacKevett, E.M., Jr., Smith, J.G., Jones, D.L., and Winkler, G.R., 1978, Geologic map of the McCarthy C-8 Quadrangle, Alaska: U.S. Geological Survey Geologic quadrangle Map GQ-1418, scale 1:63,360.

Magoon, L.B., Adkison, W.L., and Egbert, R.M., 1976, Map showing geology, wildcat wells, Tertiary plant fossil localities, K-Ar age dates, and petroleum operations, Cook Inlet area, Alaska: U.S. Geological Survey Miscellaneous Geolugic Investigations Map I-1019, scalc 1:250,000, 4 sheets.

Mancini, E.A, Deeter, T.M., and Wingate, F.H., 1978, Upper Cretaceous arc-trench gap sedimentation on the Alaska Peninsula: Gcology, v. 6, no. 7, p. 437-439.

Marshak, R.S., and Karig, D.E., 1977, Triple junctions as a cause for anomalously near-trench igncous activity between the trench and volcanic arc: Geology, v. 5, p. 233-236.

Martin, G.C., 1926, The Mesozoic stratigraphy of Alaska: U.S. Geological Survey Bulletin 776, $493 \mathrm{p}$.

McMillan, S.L., 1984, The gcology, alteration, and sulfide mineralization of Sheep Mountain, Matanuska Valley, soulheentral Alaska, [M.S. thesis]: University of Alaska, Fairbarks, Alaska, $112 \mathrm{p}$.

Miyashiro, Akiho, 1974, Volcanic rock series in island ares and active continental margins: Amcrican Journal of Science, v. 274, p. 321-355.

Moll, EJJ, and Patton, W.W., 1983, Late CretaccousEarly Tertiary calc-alkalic volcanic rocks of western Alaska: Geological Society of America Abstracts with Progtams, v. 15, no. 5, p. 406.

Monteverde, D.H., 1984, Tonalite and trondhjemite plutonism in the western Chugach Mountains, southern Alaska: an example of zear trench magmatism: Bethlehem, LeHeigh University, M.S. thesis, $82 \mathrm{p}$.

Moore, J.C., 1973, Cretaceous continental margin sedimentation, southwestern Alaska: Geological Society of America Bulletin, v. 84, no. 2, p. 595613.

1978, Orientation of underthrusting during latest Cretaceous and earliest Tertiary time, Kodiak Islands, Alaska: Geology, v. 6, p. 209-213.
Moore, J.C., Byrne, Tim, Plumley, P.W., Reid, Mary, Gibbons, Helen, and Coc, R.S., 1983, Paleogene evolution of the Kodiak Islands, Alaska: Consequences of ridge-trench interaction in a more southerly latitude: Tectonics, v. 2, no. 3, p. 265-293.

Moore, J.C., and Connelly, William, 1977, Subduction, arc volcanism, and forearc sedimentation during the early Mesozoic, in Talwani, Manik, and Pitman, W.C., III, eds. Island arcs, deep sea trenches aod back-arc basins: Washington, D.C., American Geophysical Union, p. 71-82.

Moore, J.C., and Whecler, R.S., 1978, Structural fabric of a melange, Kodiak Islands, Alaska: American Journal of Science, v. 278, p. 739-765.

Morse, S.A., 1980, Basalts and phase diagrams: An introduction to the quantitative use of phase diagrams in igneous petrology: New York, Springer-Verlag, 493 p.

Nelson, S.W., Blome, C.D., Harris, A.G., Reed, K.M., Wilson, F.H., 1986, Late Paleozoic and early Cretaccous fossil ages from the McHugh Complex: in Barlsch-Winkler, S. and Reed, K.M., eds., Gcologic studies in Alaska by the U.S. Geological Survey during 1985: U.S. Geological Survey Circular 978, p. 60-64.

Newberry, R.J., 1986, Mincral resources of the north-central Chugach Mountains, Alaska: Alaska Division of Geological and Geophysical Surveys Report of Investigations 86-23, 44 p.

Newberry, R.J., Burns, L.E., and Pessel, G.H., 1986, Volcanogenic massive sulfide deposits and the "missing complement" to the calc-alkaline trend: Evidence from the Jurassic Talkeetna island arc of southern Alaska: Economic Geology, v. 81, no. 4, p. 951-960.

Nilsen, T.H., and Zuffa, G.G., 1982, The Chugach terrane, a Cretaceous trench-fill deposit, southern Alaska, in Legget, J.K, ed., Trench and Forearc Basin Sedimentation: Geological Society of London Special Paper, [in press].

Nokleberg, WJ., Plafker, George, Winkler, G.R. Pessel, G.H., and Wallace, W.K, 1985, Accretionary tectonics along the northern Chugach Mountains and southern Copper River Basin, Alaska, [abs.]: Geological Society of America Abstracts with Programs, v. 17, no. 6, p. 397.

Palmer, A.R., 1983, The Decade of North American Gcology 1983, Geologic time scale: Geology, v. 11, p. $503-504$.

Pavlis, T.L., 1982a, Deformation along a Late Mesozoic convergent margin: The Border Ranges 
fault system, southern Alaska: Salt Lake City, University of Utah, Ph.D. thesis, $250 \mathrm{p}$. $1982 \mathrm{~b}$, Origin and age of the Border Ranges fautt of southern Alaska and its bearing on the late Mesozoic tectonic evolution of Alaska: Tectonics, v. 1, no. 4, p. 343-368.

1982c, A metamorphosed pre-Jurassic subduction complex(?) in the western Chugach Mountains, Alaska, [abs.]: Gcological Society of America Abstracts with Programs, v, 14, no. 4, p. 224.

1983, Pre-Cretaceous crystalline rocks of the western Chugach Mountains, Alaska: Nature of the basement of the Jurassic Peninsular terranc: Geological Society of Amcrica Bulletin, v. 94, no. 11, p. 1329-1344.

1985, Structural styles in the Mesozoic accretionary complex of the northern Chugach Mountains, Alaska, [abs.]: Gcological Socicty of America Abstracts with Programs, v. 17, no. 6, p. 400.

1986, Preliminary geologic map of the Anchorage C.5 Quadrangle: Alaska Division of Geological and Geophysical Surveys Public-data Filc 86-7, scale 1:63,360, 1 sheet.

Pavlis, T.L., and Brukn, R.L., 1983, Deep-seated flow as a mechanism for the uplift of broad forcarc ridges and its role in the exposure of high $\mathrm{P} / \mathrm{T}$ metamorphic terranes: Tectonics, v. 2 , nо. 5 , p. 473-497.

Pavlis, T.L., Monteverde, D.H., Bowman, J.R., Rubenstone, J.L., and Reason, M.D., 1988, Early Cretaceous near-trench plutonism in southern Alaska: A tonalite-trondhjemite intrusive complex injected during ductile thrusting along the Border Ranges fault system: Tectonics, v. 7, no. 6, p. 1179-1199.

Pessel, G.H., Henning, M.W., and Burns, L.E., 1981, Preliminary geologic map of parts of the Anchorage C-1, C-2, D-1, and D-2 Quadrangles, Alaska: Alaska Division of Geological and Geophysical Surveys Open-file Report 121.

Plafkes, George, Jones, D.L., Hudson, T.G., and Berg, H.C., 1976, The Border Ranges fault system in the Saint Elias Mountains and Alexander Archipelago: in Cobb, E.H., ed., The U.S. Geological Survey in Alaska: Accomplishments during 1975: U.S. Geological Survey Circular 733, p. 14-16.

Plafker, George, Jones, D.L., and Pessagno, EA., Jr., 1977, A Crctaceous accretionary flysch and melange terrane along the Gulf of Alaska margin: in Blean, K.M., ed., The U.S. Geological Survey in Alaska: Accomplishments during 1976: U.S. Geological Survey Circular 751-B, p. 41-43.
Plafker, Gcorgc, Ambos, E.L., Fuis, G.S., Mooncy, W.D., Nokleberg, W.J., and Campbell, D.L., 1985, Accretion subduction and underplating along the southern Alaska Continental margin: Geological Society of America Abstracts wilh Programs, v. 17, no. 7, p. 690.

Reger, R.D., and Updike, R.G., 1983, Upper Cook Inlet region and the Malanuska Valley: in Péwe, T.L., and Reger, R.D., eds., Guidebook to pcrmafrost and Quaternary geology along the Richardson and Glenn Highways belween Fairbanks and Anchorage, Alaska: Alaska Division of Gcological and Geophysical Surveys Guidebook 1, p. 185-259.

Richter, D.H., and Dutro, .J.T., Jr., 1975, Revision of the type Mankommen Formation (Pennsylvanian and Permian), Eagle Creek area, eastern Alaska Range, Alaska: U.S. Gcological Survey Bulletin 1395-B.

Ross, M., and Huebner, J.S., 1975, A pyroxene gcothcrmometer based on composition icmpcrature rclationships of naturally occurring orthopyroxene, pigconite, and augite, [abs.]: in Extended abstracts of the International Conference of Geothermometry and Gcobarometry; Pennsylvania State University, University Park, Pennsylvania, p. 4.

Sample, Jim, 1985, An ancient underplated sequence preserved in the Kodiak Islands, Alaska: Geological Socicty of America Abstracts with Programs, v. 17, no. 6, p. 406.

Schrader, S.C., 1899, Rcport on Prince William Sound and the Copper River region: in Maps and descriptions of routes of exploration in Alaska in 1898, with general information coscerning the tcrritory: U.S. Geological Survey Special Publication, p. 51-63.

1900, A reconnaissance of a part of Prince William Sound and the Copper River district, Alaska in 1889: U.S. Geological Survcy 20th Annual Report, part 7, p. 341-423.

Serfes, M.E., 1984, The Wolverine Creck Fault System - A newly ecognized terrane boundary in the western Chugach Mountains of southern Alaska: Bethlehem, LcHigh University, M.S. thesis, $67 \mathrm{p}$.

Sibson, R.H., 1977, Fault rocks and fault mechanisms: Journal Geological Society of London, v. 133, p. 191-213.

Silberman, M.L., and Grantz, Arthur, 1984, Paleogene volcanic rocks of the Matanuska Valley area and the displacement history of the Castle Moumain fault: in Coonrad, W.L. and Ellott, R.L., eds., The U.S. Geological Survey in 
Alaska: Accomplishments during 1981: U.S. Geological Survey Circular 868, p. 82-86.

Sisson, V.B., and Hollister, L.S., 1985, Relation of magma intrusion to deformation and uplift of eastern Chugach Mountains, Alaska [abs]: Geological Society of America Abstracts with Programs, v. 17, no. 6, p. 408.

1986, Rapid two-stage metamorphism of the eastern Chugach Mountains, southern Alaska [abs]: Geological Society of America Abstracts with Programs, v. 18, no. 2, p. 186.

Smilh, J.G., and MacKevett, E.M., Jr., 1970, The Skolai Group in the McCarthy B-4, C-4, and C-5 Quadrangles, Alaska: in Contributions to stratigraphy: U.S. Gcological Survey Bulletin 1274-Q, p. Q1-Q26.

Streckeiscn, Albert, 1976, To each plutonic rock its proper name: Earth Science Review, v. 12, no. 1, p. 1-35.

Suppe, John, 1983, Gcometry and kinematics of fault-bend folding: American Journal of Science, v. 283 , p. 684-721.

Triplchorn, D.M., Turner, D.L., and Nacser, C.W., 1984, Radiometric age of the Chickaloon Formation of south-central Alaska: Location of Paleoccne-Eocene boundary: Gcological Society of America Bulletin, v. 95, no. 6, p. 740-742.

Tysdal, R.G, and Plafker, George, 1978, Age and continuily of the Valdez Group, southern Alaska: in Sohl, N.F., and Wright, W.B., eds., Changes in stratigraphic nomenclature of the U.S. Geological Survey: U.S. Geological Survey Bulletin 1457-A, p. A120-A124.

Updike, R.G., and Ulery, CA., 1983, Preliminary geologic map of the Anchorage B-6 NW (Eklutna Lake) Quadrangle: Alaska Division of Geological and Geophysical Surveys Report of Investigation 83-8, scale 1:10,000, 2 sheets.

Wallace, W.K., and Engebretson, D.C., 1984, Relationships between plate motions and Late Cretaceous to Paleogene magmatism in southwestern Alaska: in Correlation between plate motions and Cordilleran tcctonics, Tectonics, v. 3, no. 2, p. 293-315.
Waring, GA., 1936, Geology of the Anthracite Ridge coal district: U.S. Geological Survcy Bulletin 861, 57 p., scale 1:62,500, 13 sheets.

Winkler, G.R., 1978, Framework grain mineralogy and provenance of sandstone from the Arkose Ridge and Chickaloon Formations, Matanuska Valley: in Johnson, K.M., ed., The U.S. Geological Survey in Alaska: Accomplishments during 1977: U.S. Geological Survey Circular 772-B, p. B70-B73.

Winkler, G.R, Miller, R.J., and Case, J.E., 1981a, Blocks and belts of blueschist and greenschist in the northwestern Valdez Ouadrangle, Alaska: in Albert, N.R.D., and Hudson, Travis, eds., The U.S. Gcological Survey in Alaska: Accomplishments during 1979: U.S. Geological Survey Circular 823-B, p. B72-B74.

Winkler, G.R., Sibberman, M.L., Grantz, Arthur, Miller, R.J., and MacKeveth, E.M., Jr., 1981b, Gcologic map and summary geochronology of the Valdez Quadrangle, southern Alaska: U.S. Gcological Survey Open-file Report 80-892-A, scale $1: 250,000,2$ sheets.

Winkler, G.R., comp., 1990, Preliminary geologic map, cross sections, and summary geochronology of the Anchorage Quadrangle, southern Alaska: U.S. Geological Survcy Open-file Report 90-83, scale $1: 250,000,2$ sheets.

Winkler, Helmut G.F., 1974, Petrogenesis of mctamorphic rocks, [4th ed.]: New York, Springer-Verlag, $334 \mathrm{p}$.

Wolfe, JA., 1966, Tertiary plants from the Cook Inlet region, Alaska: U.S. Geological Survey Professional Paper 398-B, p. B1-B32.

Wolfe, J.A., Hopkins, D.M., and Leopold, E.B., 1966, Tertiary stratigraphy and palcobotany of the Cook Inlet region, Alaska: U.S. Geological Survey Professional Paper p. 398-A, p. A1-A29.

Woodcock, N.H., 1977, Specification of fabric shapes using an eigenvalue method: Geological Society of America Bulletin, v. 88, no. 9, p. 1231-1236. 
STAFF

Thomas E. Smith, Acting State Geologist

\section{Minerals and Energy Resources}

G.H. Pessel, Geologist ${ }^{2}$

N.D. Bowman, Geology Assistant

T.K. Bundtzen, Geologist

L.E. Burns, Geologist

K.H. Clautice, Geologist

J.G. Clough, Geologist

W.G. Gilbert, Geologist

E.E. Harris, Geologist

S. A. Liss, Geologist

C.G. Mull, Geologist

J.W. Reeder, Geologist

R.R. Reifenstuhl, Geologist

M.S. Robinson, Geologist

D.N. Solie, Geologist

Resource Information

G.M. Laird, Publications Specialist ${ }^{2}$

R.A. Mann, Clerk

J.A. Outten, Publications Technician

A-L. Schell, Cartographer

A.G. Sturmann, Cartographer

F.C. Tannian, Publications Specialist

\section{Engineering Geology}

R.A. Combellick, Geologist ${ }^{2}$

J.T. Kline, Geologist

G.D. March, Geologist

R.J. Motyks, Goologist

C.J. Nye, Geologist

R.D. Reger, Geologist

M.A. Wiltse, Chemist

J.J. Vohden, Chemist

Administrative Services

P.M. Verosta, Administrative Assistant ${ }^{2}$

K.E. Brown, Clerk Typist

D.L. Chavez, Secretary

R.A. Czajka, Clerk Typist

R.R. Groner, Accounting Technician

M. G. Murphree, Clerk Typist

J.M. Robinson, Adouinistrative Assistant

In addition to the permanent staff listing above, DGGS presently employs 14 students in the Department of Natural Resources Student Intern Program.

${ }^{2}$ Section chief. 